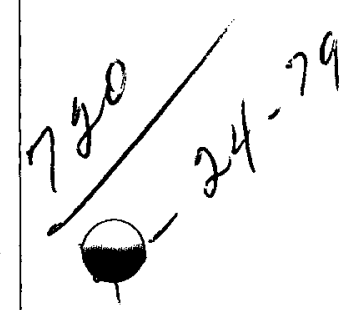

\title{
DR. 249
}

NVO-0671-2
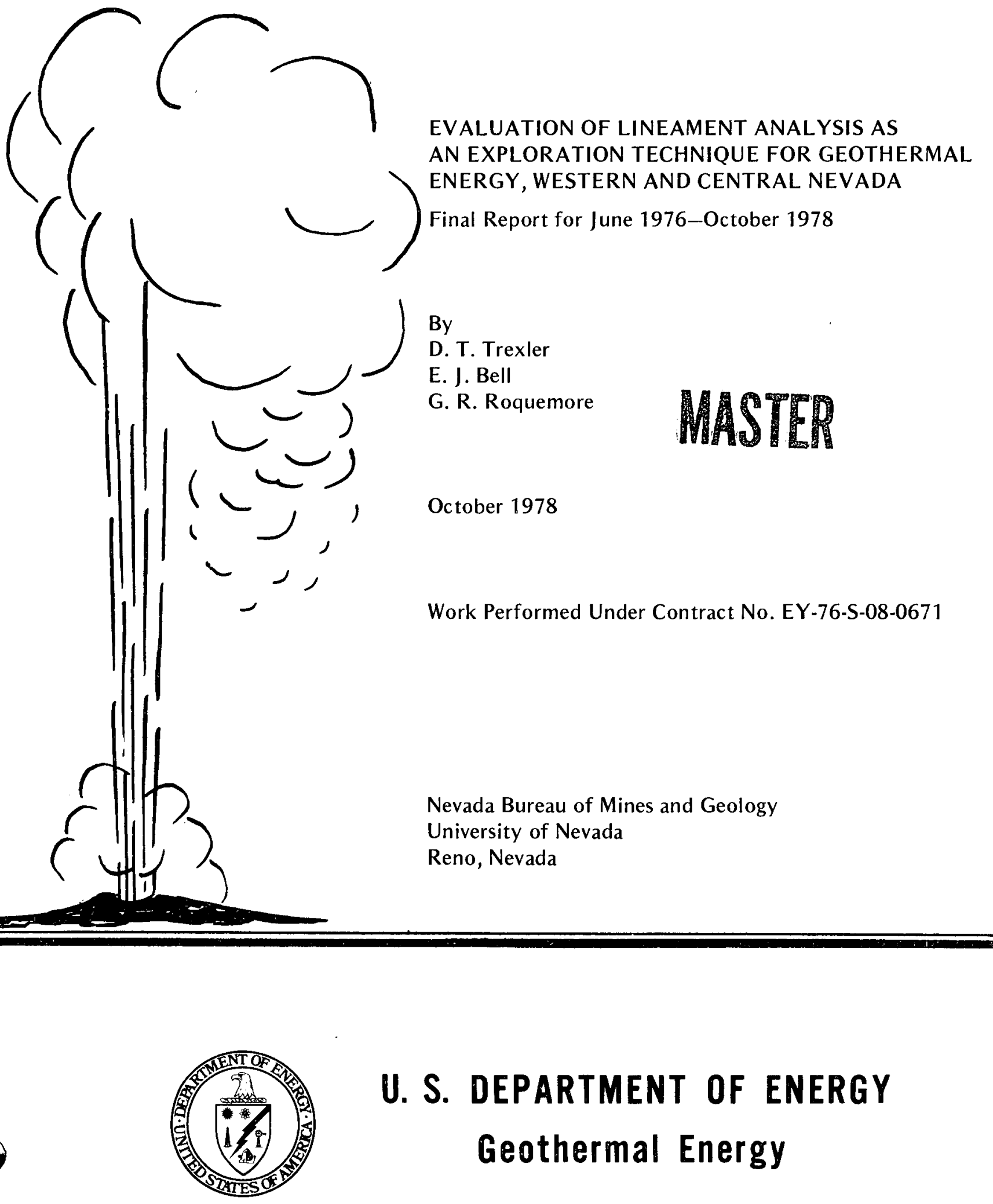

\section{U. S. DEPARTMENT OF ENERGY Geothermal Energy}




\section{NOTICE}

This report was prepared as an account of work sponsored by the United States Government. Neither the United States nor the United States Department of Energy, nor any of their employees, nor any of their contractors, subcontractors, or their employees, makes any warranty, express or implied, or assumes any legal liability or responsibility for the accuracy, completeness or usefulness of any information, apparatus, product or process disclosed, or represents that its use would not infringe privately owned rights.

This report has been reproduced directly from the best available copy.

Available from the National Technical Information Service, U.S. Department of Commerce, Springfield, Virginia 22161.

Price: Paper Copy $\$ 6.00$

Microfiche $\$ 3.00$ 


\section{DISCLAIMER}

This report was prepared as an account of work sponsored by an agency of the United States Government. Neither the United States Government nor any agency Thereof, nor any of their employees, makes any warranty, express or implied, or assumes any legal liability or responsibility for the accuracy, completeness, or usefulness of any information, apparatus, product, or process disclosed, or represents that its use would not infringe privately owned rights. Reference herein to any specific commercial product, process, or service by trade name, trademark, manufacturer, or otherwise does not necessarily constitute or imply its endorsement, recommendation, or favoring by the United States Government or any agency thereof. The views and opinions of authors expressed herein do not necessarily state or reflect those of the United States Government or any agency thereof. 


\section{DISCLAIMER}

Portions of this document may be illegible in electronic image products. Images are produced from the best available original document. 
NVO-0671-2

Distribution Category UC-66a

EVALUATION OF LINEAMENT ANALYSIS AS AN EXPLORATION TECHNIQUE FOR GEOTHERMAL ENERGY, WESTERN AND CENTRAL NEVADA

FINAL REPORT

FOR THE PERIOD

JUNE 1976 - OCTOBER 1978

D. T. TREXLER, E. J. BELL and G. R. ROQUEMORE

NEVADA BUREAU OF MINES AND GEOLOGY

UNIVERSITY OF NEVADA, RENO

RENO, NEVADA 89557

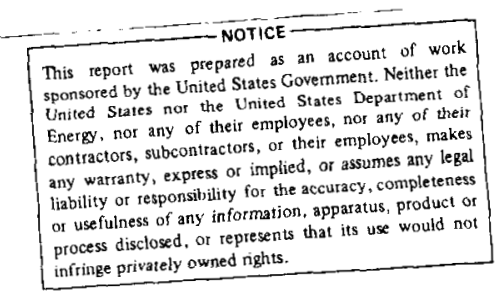

\section{MASTER}

PREPARED FOR THE

U. S. DEPARTMENT OF ENERGY

DIVISION OF GEOTHERMAL ENERGY

UNDER CONTRACT EY-76-S-08-0671 


\section{ABSTRACT}

Lineament analysis as an exploration technique for geothermal energy using multi-scale, multi-format imagery and geophysical data is investigated and evaluated. Two areas in Nevada, each having distinct differences in structura1 style were studied. One area, which encompasses a portion of the Battle Mountain Heat Flow High, was studied to determine the relationship between regional and local structural controls and geothermal activity. Four geothermal sites within this area (Winnemucca AMS) were selected and studied in detail. These sites include: 1) Leach Hot Springs, 2) Kyle Hot Springs, 3) Beowawe geothermal area and Buffalo Valley Hot Springs. A second area encompassed by the Reno AMS Sheet was selected for further study in a region dominated by three diverse tectonic styles; these are: 1) the Sierra Nevada Front, 2) the Walker Lane, and 3) basin-and-range structures. Geothermal sites analyzed at site specific scales within the Reno AMS Sheet included Steamboat Hot Springs in the Sierra Nevada Front subprovince, Dixie Valley Hot Springs located in typical basin-andrange terrain and the Brady's-Desert Peak area which is marginal to the Walker Lane.

Data products employed included LANDSAT imagery, SKYLAB photography, gravity and aeromagnetic maps. Most of the formats were analyzed at multiple scales. LANDSAT mosaics afforded integration of regional lineament patterns to the areas of investigation. Computer enhanced LANDSAT imagery and high quality SKYLAB photography provided for intermediate scale structural analysis of the areas. Low sun-angle aerial photography was used at site specific scales to determine the relationship between geothermal activity and structures.

Results of this investigation indicate that in north-central Nevada the major sites of geothermal activity are associated with northeast trending structures related to the Midas Trench lineament and that the most viable geothermal area (Beowawe) is located at the intersection of the northeast trend of the Oregon-Nevada Lineament. Although significantly different tectonic forces have been operative in western Nevada (Reno AMS Sheet) similar relationships between geothermal activity and the intersection or disruption of major lineament trends are apparent.

The usefulness of each of the data formats is evaluated with respect to regional reconnaissance and site specific exploration for geothermal resources. LANDSAT provides information on regional scale lineament trends. Multiple scales of imagery optimize data extraction capabilities. SKYLAB photographic products provide the necessary medium for transition from regional to site specific scales. Low sun-angle photography at multiple scales, acquired concurrently provide the maximum amount of information for site specific correlation of structures and geothermal activity. 
INTRODUCTION. . . . . . . . . . . . . . . . . . . . . . . 1

INTERPRETIVE TECTHNTQUES AND LINEAMENT ANALYSIS . . . . . . . . . . 3

LANDSAT BAND 5 LINEAMENT ANALYSIS . . . . . . . . . . . . . . 5

SKYLAB S190-B INTERPRETATION . . . . . . . . . . . . . . . . 8

AEROMAGNETIC DATA INTERPRETATION .................... . 11

GRAVITY DATA INTERPRETATION. . . . . . . . . . . . . . . 13

COMPARISON OF LINEAMENT TRENDS . . . . . . . . . . . . . . . . . 18

SITE SPECIFIC STUDIES. . . . . . . . . . . . . . . . . 25

LEACH HOT SPRINGS . . . . . . . . . . . . . . . . 25

BUFFALO VALLEY HOT SPRINGS. . . . . . . . . . . . . . . 27

KYLE HOT SPRINGS. . . . . . . . . . . . . . . . . 30

BEOWAWE GEOTHERMAL AREA . . . . . . . . . . . . . . . 32

INTRODUCTION PHASE II. . . . . . . . . . . . . . . . . 37

GRAVITY AND AEROMAGNETIC LINEAMENTS OF THE RENO AMS SHEET. . . . . • . 37

LANDSAT AND SKYLAB LINEAMENT ANALYSIS OF THE RENO AMS SHEET. • • • • • . 39

RELATIONSHIP OF STRUCTURAL STYLE ALONG THE SIERRA NEVADA

FRONT AND GEOTHERMAL ACTIVITY. . . . . . . . . . . . . . . . . . . 44

RELATIONSHIP BETWEEN GEOTHERMAL OCCURRENCES AND YOUNG

VOLCANIC ROCKS WITH THE STRUCTURES IN THE RENO AMS SHEET . . . . . . . . 50

SITE SPECIFTC STUDIES WITHIN THE RENO AMS SHEET. . . . . . . . . . . . 56

BRADY'S HOT SPRINGS - DESERT PEAK AREA. . . . . . . . . . . . 56

DIXIE HOT SPRINGS . . . . . . . . . . . . . . . . 59

EVALUATION OF DATA TYPES AND FORMATS . . . . . . . . . . . . . . . 69

GRAVITY MAPS. . . . . . . . . . . . . . . . 69

AEROMAGNETIC DATA . . . . . . . . . . . . . . . . . 69

LANDSAT DATA. . . . . . . . . . . . . . . . . . 69

SKYLAB PHOTOGRAPHY. . . . . . . . . . . . . . . . . . 70 
LOW SUN-ANGLE PHOTOGRAPHY (LSAP). . . . . . . . . . . 70 SUMMARY AND CONCLUSIONS. . . . . . . . . . . . . . . . . . 71 REFERENCES . : . . . . : . . . . . . . . . . . . . . . 75 
FIGURE 1. Location map of Reno and Winnemucca AMS Sheets. . . . . . . . . 2

FIGURE 2. LANDSAT lineament interpretation of northern Nevada . . . . . . 6

FIGURE 3. SKYLAB S190-B photograph of a portion of the
Winnemucca AMS sheet. . . . . . . . . . . . . . . . 9

FIGURE 4. Generalized total-intensity aeromagnetic map
of the Winnemucca AMS sheet . . . . . . . . . . . . 12

FIGURE 5. Bouguer gravity map of Nevada . . . . . . . . . . . . . . . . . . 14

FIGURE 6. Filtered Bouguer gravity map of Nevada. . . . . . . . . . . . . 16

FIGURE 7. Bouguer gravity map of the Winnemucca AMS sheet . . . . . . . . . 17

FIGURE 8. Frequency plot of LANDSAT 1ineaments of northern Nevada . . . . 19

FIGURE 9. Frequency plot of LANDSAT lineaments in the Winnemucca

AMS sheet...................... . . 21

FIGURE 10. Frequency plot of fault trends in the Beowawe
Geothermal Area . . . . . . . . . . . . . . . 21

FIGURE 11. Relationship between structures and geothermal

FIGURE 12. Low sun-angle aerial photograph of the Leach Hot Springs

area shwoing northeast trending faults in alluvium. . . . . . . 28

FIGURE 13. Low sun-angle aerial photograph of Buffalo Valley showing

the distribution of Quarternary basaltic cinder cones . . . . . 31

FIGURE 14. Low sun-angle aerial photograph of the Kyle Hot Springs

area. . . . . . . ... . . . . . . . . . . . 33

FIGURE 15. Low sun-angle aerial photograph of the Beowawe area,

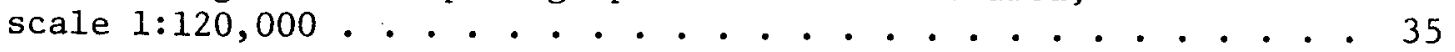

FIGURE 16. Frequency plot of lineaments from computer enhanced

LANDSAT imagery of the northeast Reno AMS sheet . . . . . . . . 41

FIGURE 17. Frequency plot of lineaments from computer enhanced

LANDSAT imagery of the southwest Reno AMS sheet . . . . . . . 41

FIGURE 18. Frequency plot of lineaments from SKYLAB S-190B photo-

graphy of the south-central Reno AMS sheet. . . . . . . . . 43

FIGURE 19. Frequency plot of lineaments for the entire Reno

AMS sheet (LANDSAT imagery) . . . . . . . . . . . . 43

FIGURE 20. Map showing patterns of faulting in the Steamboat

Hot Springs area. . . . . . . . . . . . . . . 45 
FIGURE 21. Sierra Nevada front from the Garlock fault to Mono Lake, California. . . . . . . . . . . . . . .

FIGURE 22. Portion of the Sand Springs Range. . . . . . . . . . . . 51

FIGURE 23. Relationship between structures and geothermal activity within the Reno AMS sheet . . . . . . . . . 52

FIGURE 24. Frequency plot of faults in the Brady's Hot Springs

- Desert Peak area (conventional AMS photography). . . . . 57

FIGURE 25. Frequency plot of faults in Brady's Hot Springs

- Desert Peak area (U-2 photography) . . . . . . . . 57

FIGURE 26. Frequency plot of faults in Dixie Valley Hot Springs area. . 60

FIGURE 27. Map of the Dixie Valley area showing the range front and valley segments of the Dixie Valley fault zone . . . . . 62

FIGURE 28. Photograph and map of the central portion of the IXL quadrangle . . . . . . . . . . . . . . .

FIGURE 29. Profiles across range front fault (upper) and the valley segment (1ower) of the Dixie Valley fault zone . . . . . 64

FIGURE 30. Photograph and map of the northern portion of the IXL quadrangle showing the ENE-WNW faulting which produces "sawtooth" appearance . . . . . . . . . . 65

FIGURE 31. Photograph and map in the northeast portion of the IXL quadrangle showing two splays of the valley branch fault.....................

FIGURE 32. Photograph and map of the central portion of the SE1/4 of Dixie Hot Springs 15-minute quadrangle. . . . . 


\section{INTRODUCTION}

The usefulness of lineament analysis as an exploration technique for geothermal energy is evaluated in an area of north-central Nevada that has been extensively studied using geological, geophysical, and remote sensing techniques. The results of the initial phase of the program were followed by the application of these results to an area with geothermal potential which is complicated by several diverse tectonic histories.

The areas selected for the first phase of the program were the geothermal areas: wịthin the Winnemucca AMS Sheet (NK11-11, fig. 1). This area of northcentral Nevada has four hot spring areas that haye been studied by Lawrence Berkeley Laboratory (LBL). The data compiled by LBL and other sources were used to support the lineament analysis of Beowawe geothermal area, Buffalo Valley, and Leach and Kyle Hot Springs. The regional lineaments apparent only on sate11.ite imagery were compared to low sun-angle photography obtained by U-2 aircraft, supplemented by gravity and aeromagnetic data. The distribution of hot springs, hot wells, sinter deposits, and yolcanic rocks less than $6 \mathrm{~m} \cdot \mathrm{y}$. was correlated with major crustal lineaments and mapped faults.

The second phase of the study applied the methodology and relationships that were noted in the first phase to the Reno AMS Sheet (NJ11-1, fig. 1). The area encompassed by the Reno AMS Sheet exhibits several diverse structural settings including: 1) Sierran Front; 2) Walker Lane; and 3) Basin and Range. The purpose of this phase of the study was to confirm that the spatial relationship between hot springs and geologic structures was valid and that they could be used in a structural setting other than typical Basin and Range.

During the first phase of this investigation, lineament analysis of multiscale, multi-format spacecraft and aircraft imagery and photographic products was made to determine the association and/or distribution of hot springs. 


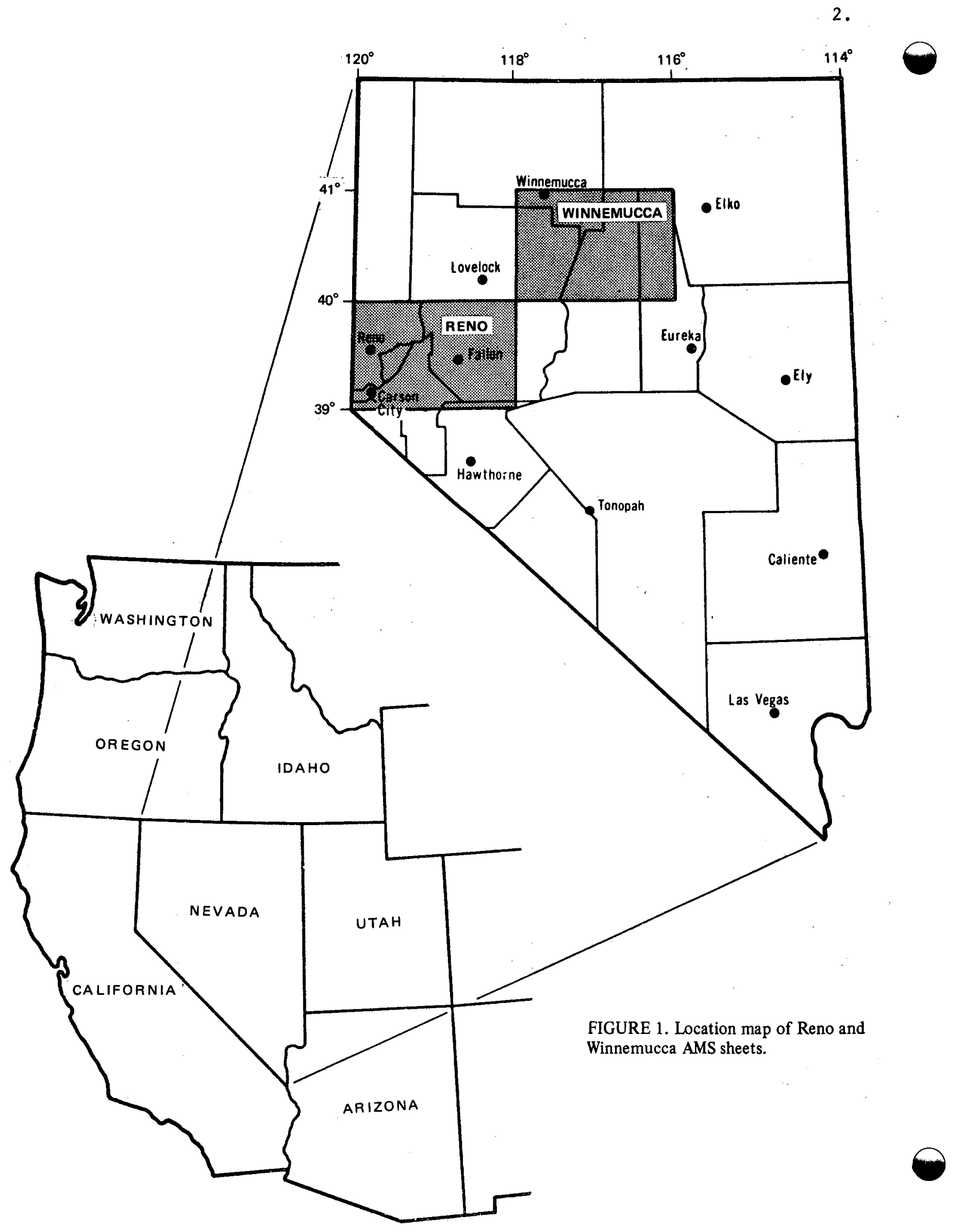


relative to lineaments. Significant results from each of the data formats, including LANDSAT, SKYLAB, and U-2 low sun-angle photography, will be discussed subsequently. Regional tectonic patterns in north-central Nevada have been mapped on LANDSAT imagery employing techniques used by numerous investigators (Rowan and Wetlaufer, 1973 and 1975; Levandowski and others, 1974; Hoppin, 1974; Abdel-Gawad and Tubbesing, 1974). To supplement the lineament analysis of the imagery and photographic products, geophysical data including magnetics, gravity, and seismicity, as well as previous work by numerous investigators relating one or more of the geophysical phenomena to geologic structure and regional tectonics, were used (Levandowski and others, 1974; Stewart and others, 1975; Robinson, 1970; Koizumi and others, 1973; Thompson and Burke, 1974; Quade and Trexler, 1975; Ryal1, 1977; and Suppe and others, 1975). Previous works by several investigators (Wright, 1976; Hamilton and Myers, 1966; Sales, 1966; Wise, 1963; Shawe, 1965) were compared to evaluate the lineament analysis and the relationship of lineaments to the Cenozoic tectonic framework of the Basin and Range. Intermediate scale $(1: 250,000)$ structural analysis was performed using SKYLAB S190-B photography over the Battle Mountain, Nevada, area. The resolution of the SKYLAB photography, which exceeds that of LANDSAT imagery by several orders of magnitude, provided synoptic coverage of the area of investigation and delineated the relationship between Cenozoic basin-and-range faulting and geothermal areas.

Low sun-angle photography at scales of $1: 120,000$ and $1: 30,000$ provided site specific information of the structural setting of four geothermal areas within the Battle Mountain heat flow high (Sass and others, 1971).

\section{INTERPRETIVE TECHNIQUES AND LINEAMENT ANALYSIS}

Interpretive techniques varied with the scale and resolution of the various data formats. Interpretation of a LANDSAT imagery mosaic at a scale of 
1:1,000,000 of Band 5 (Soil Conservation Service) was made by delineating tonal discontinuities, alignments or breaks in topographic features, and vegetation alignments. The major lineaments can be traced through bedrock areas and in some instances across alluvial valleys. Recent work by Robert Reeves (personal commun., 1977) using computer enhanced LANDSAT imagery and detailed gravity measurements along the western margin of the Winnemucca AMS Sheet has shown that northeast-southwest trending structures, visible in bedrock areas of the East Range, can be detected beneath valley fill in Buena Vista Valley.

Since the resolution of the SKYLAB S190-B Earth Terrain Camexa (18 in. F.L.) is comparable to conventional aerial photography, airphoto interpretation techniques could be used. Faults and linear fractures were mapped on 1:250,000 scale enlargements of the original $11.4 \times 11.4 \mathrm{~cm}(4.5 \times 4.5 \mathrm{in}$, in 1:950,000 scale) format. This scale of enlargement did not appreciably decrease the resolution of the photographs.

Conventional aerial photographic interpretive techniques were used to extract fault data from the U-2 low sun-angle photography (LSAP). Various supplemental techniques, such as the use of positive transparencies and magnification which are described in detail in Walker and Trexler (1977), were also used.

Gravity and aeromagnetic data were used to supplement the image and photographic lineament interpretation and to help define the genetic relationship between the surficial lineament expression and the subsurface mechanism or mechanisms which they reflect. A simple Bouguer gravity map of the Winnemucca AMS Sheet (Erwin, 1974) was used to plot linear trends of contour closures. A generalized aeromagnetic map at 1:250,000 scale of the Winnemucca AMS Sheet was prepared from U. S. Geological Survey open-file maps (1:62,500 scale). The aeromagnetic map was analyzed for significant crustal trends as reflected in the contour closures or steep gradients. 
The existence of a high-velocity lithospheric plate under northern Nevada has been established by teleseismic P-wave arrivals (Koizumi and others, 1973). This high-velocity layer trends N60E and dips steeply to the southeast beneath Battle Mountain, Nevada. Koizumi and others (1973) interpret this high-velocity layer to be a paleosubduction zone. The relationship between the high-velocity layer and the northeast trending lineaments in north-central Nevada are not completely understood at the present time but this zone undoubtedly played a major role in the production of the major northeast trending lineaments.

\section{LANDSAT BAND 5 LINEAMENT ANALYSIS}

Lineament analysis of northern Nevada was performed on a Band 5 mosaic prepared by the U. S. Dept. of Agriculture, Soil Conservation Service. To assure that the tonal contrasts on the mosaic were real and not matched-seams of the moszicking process, the mapped lineaments were checked on individual LANDSAT frames of the same band obtained from October through March 1975. Figure 2 is a portion of the LANDSAT mosaic showing major lineament trends in northern Nevada. The interpretation includes many lineaments of Rowan and Wetlaufer (1975) and, for a detailed analysis of the techniques involved in production of an interpretive lineament analysis of LANDSAT imagery, their excellent detailed report should be consulted.

The prominent trends delineated by this analysis are in three general directions: NW, NE, and NNE-NNW. The geographic distribution of the major lineament directions is relatively uniform for northern Nevada. The NNE-NNW trends represent the expression of the Cenozoic basin-and-range faulting and may be correlated with mapped faults of the area (Stewart and Carlson, 1976; Slemmons, 1967). The northwest trends, which include from the west to east the Walker Lane (E-E'), Rye Patch Lineament (C-C') of Rowan and Wetlaufer (1973), and the Oregon-Nevada Lineament (B-B') of Stewart and others (1975), vary in azimuth 


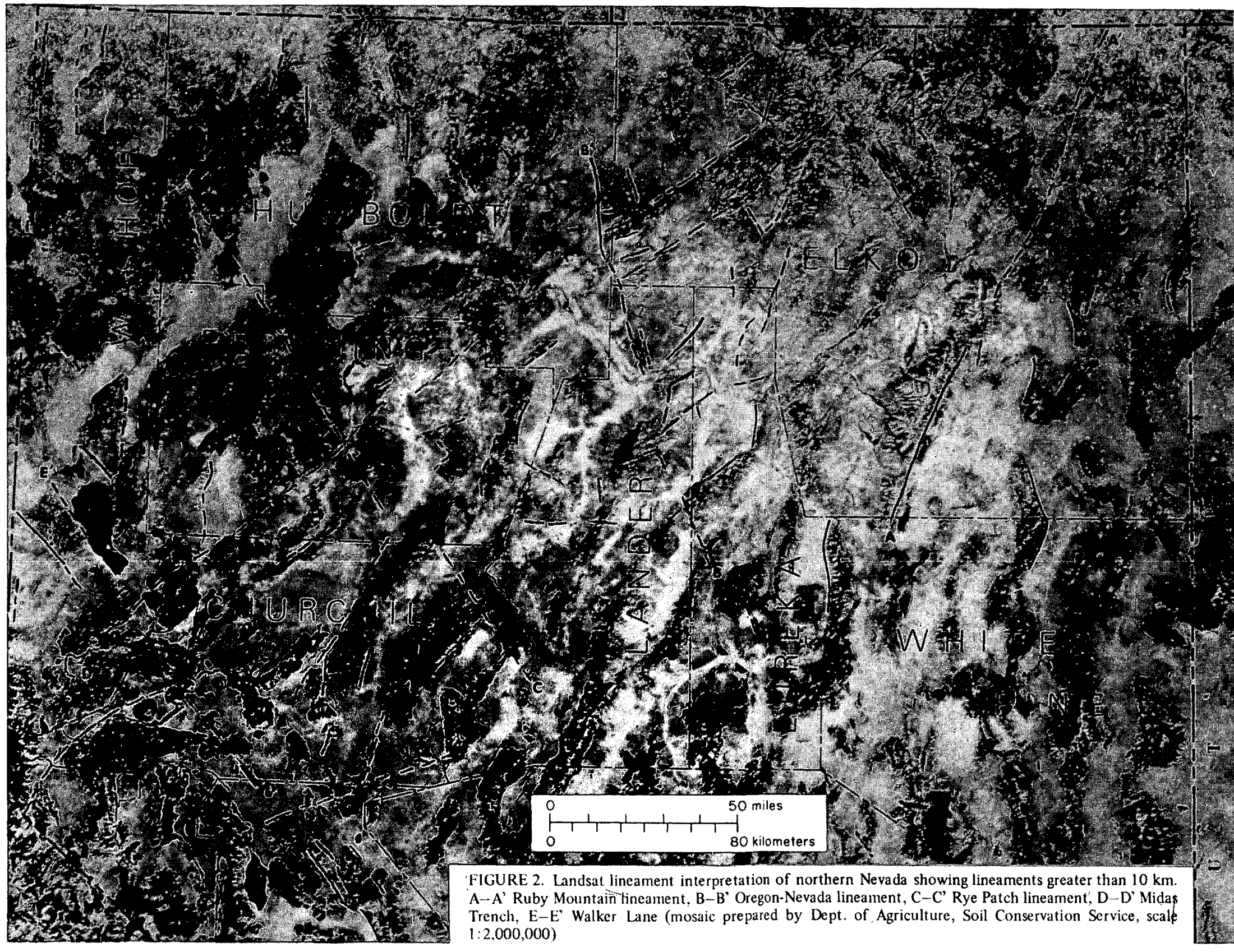


from $\mathrm{N} 40 \mathrm{~W}$ to near $\mathrm{N} 20 \mathrm{~W}$. The Walker Lane in northern Nevada has a general trend of $\mathrm{N} 40 \mathrm{~W}$ in the segment east of Walker Lake to Pyramid Lake. The trend of the Rye Patch Lineament is generally N30W for both segments (C-C') shown in figure 2. The offset in the Rye Patch Lineament may coincide with an extension of the Midas Trench (D-D'). If this separation of the Rye Patch Lineament is associated with the Midas structure, then the Midas Lineament has a left sense of movement and the southern segment (now obscured) is younger than the Rye Patch Lineament. The sense of movement on the Rye Patch Lineament appears to be right-separation due to the pinching of the northern end of the Sweetwater Range.

The nortliwest-trending lineament extending from central Eureka County to western Humboldt County $\left(B-B^{\prime}\right)$ has been named the Oregon-Nevada Lineament (Stewart and others, 1975) and consists of closely spaced en echelon faults. The lineament appears as aligned canyons and escarpments on the LANDSAT mosaic. This lineament corresponds to a positive aeromagnetic anomaly which is probably due to dikes that supplied the late Tertiary silicic volcanics that mark the zone in northern Nevada. Stewart and others (1975) consider the Nevada portion of the lineament to have developed by a complex history of strike-slip and tensional movement during the Miocene. This timing corresponds with the accepted time of inception of basin-and-range faulting in north-central Nevada (Christiansen and Lipman, 1972; Zoback and Thompson, 1978). If the Miocene age for the Oregon-Nevada Lineament is valid, then the northeast-trending Midas Lineament $\left(D-D^{\prime}\right)$ is older because its trend is interrupted by the Oregon-Nevada Lineament north of Battle Mountain. The lack of topographic expression of the Midas Lineament southwest of the Oregon-Nevada Lineament may indicate a tensional history for this portion of the lineament and separation of the older Midas system. The Midas "Trench" Lineament zone (D-D', fig. 2) extends from southern Washoe County in the southwest to the northern border of the State in central E1ko County. The southern portion of this zone is expressed as a discontinuous 
alignment of canyons and ridges. In the southern Virginia Range, Quaternary movement along a northeast trend has been mapped by Rogers (1975). In this area, pervasive northeast trending structures in the pre-Mesozoic metamorphics (Zones, 1958) suggest the existence of an older tectonic setting controlled by northeast trends with a left-separation sense of offset (Trexler, 1977). In its northeast extension in central Nevada, the zone forms a depression in the vicinity of the town of Midas and forms the border between the Owyhee Desert and mountain ranges to the southeast in northwestern Elko County. Other shorter, less distinct segments with similar NE trends can be seen in figure 2 . These segments are believed to be genetically related to the larger pervasive zone referred to as the Midas Trench.

The NNE trending lineament ( $\mathrm{A}-\mathrm{A}^{\prime}$ ) has been termed the Ruby Mountains Lineament (Rowan and Wetlaufer, 1975). It is the least documented feature in Nevada and reflects the normal fault bounding the Ruby Mountains on the east. Its northern extension appears to coincide with smaller faults (Rowan and Wetlaufer, 1975).

\section{SKYLAB S190-B INTERPRETATION}

SKYLAB S190-B photography was obtained over a portion of the Winnemucca AMS Sheet on August 12, 1973. Time of acquisition on the SL-3 Track 20 Pass was 0745 local time which provided low sun-angle $\left(28^{\circ}\right)$ illumination. Figure 3 provides a synoptic view of approximately 75 percent of the study area. The quality of the S190-B photographic data is such that it can be successfully enlarged to $1: 250,000$, allowing structural interpretations to be performed at this scale.

It is apparent from inspection of figure 3 that every facet of the structural grain of the area can be discerned. Features that correspond to regional tectonic features are noted at 1 and 2 . At location 1 and 1 a the parallel northwest trending features are coincident with the trend of the Oregon-Nevada Lineament. 


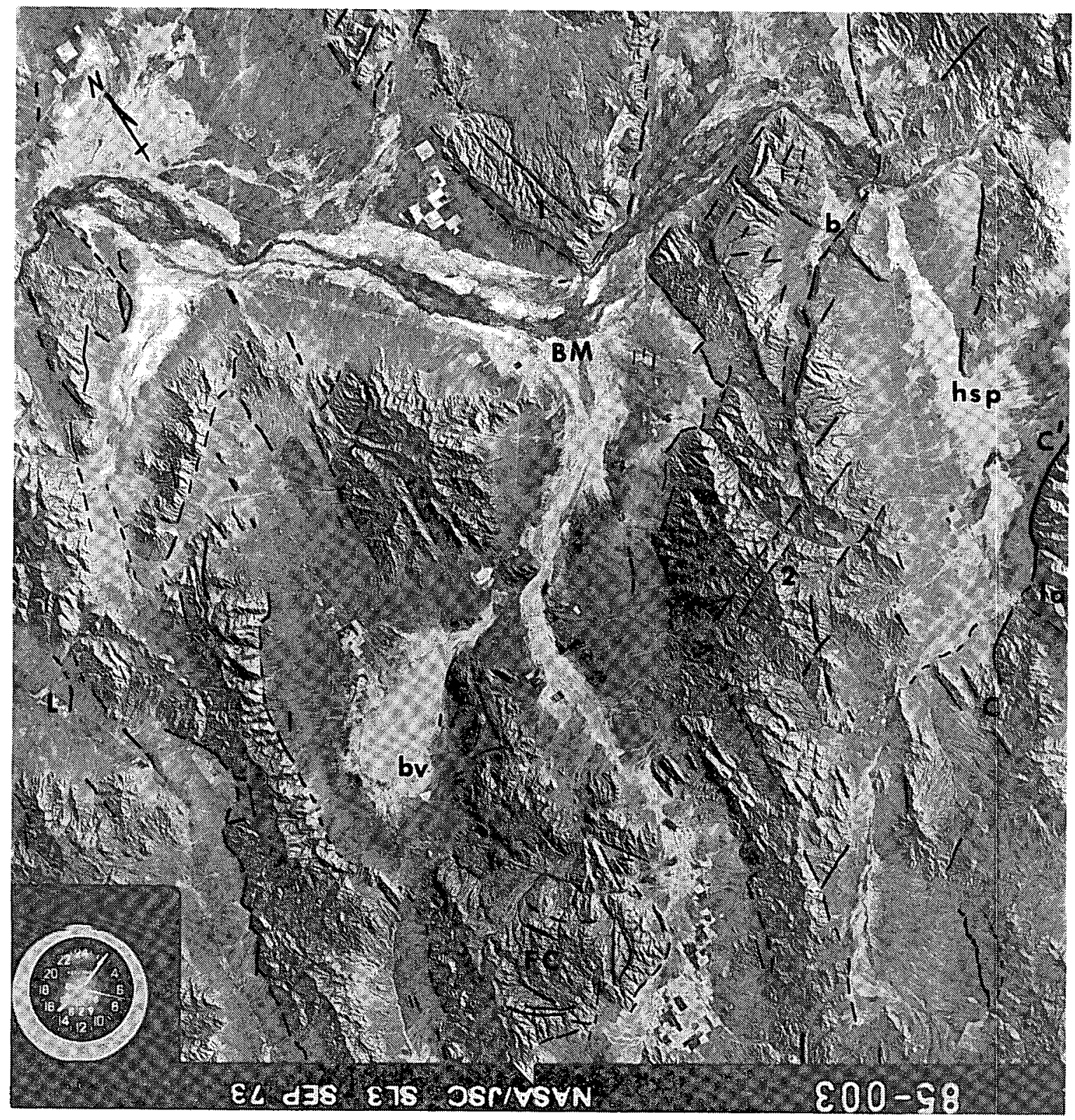

FIGURE 3. Skylab S190-B photograph of a portion of the Winnemucca AMS sheet acquired on August 12 , 1973 at 0745 local time; 1 and 1a segments of Oregon-Nevada lineament, 2 = northeast trending bedrock lineaments, $b=$ Beowawe Hot Springs, $\mathrm{BM}=$ town of Battle Mountain, $\mathrm{bv}=$ Buffalo Valley, $\mathrm{fc}=$ Fish Creek Mountains, hsp = Hot Springs Point, scale approximately 1:1,240,000. 
10 .

The northeast trending parallel structures at 2 and similar trending structures in Beowawe Hot Springs (b) are probably related to the Midas Trench system. The structures at 2 are unique in that they are in bedrock and have a crosscutting relationship to the general N-S trend of the Shoshone Range.

The northwest-southeast trending fault near Beowawe (b) may extend southeastward to include hot spring activity at Hot Springs Point (hsp) figure 3. Further extension of the northwest-southeast trending structure and its intersection with the Crescent Valley fault ( $\left.C-C^{\prime}\right)$, also a site of hot spring activity, may indicate the importance of lineament intersection.

At the scale of figure 3 , it is difficult to discern the minor faulting on the east side of Buffalo Valley (bv); therefore, it will be discussed in the site specific structure section. Northeast trends of basaltic cinder cones and faulting of alluvial valley fill with a similar trend occur in the vicinity of the hot spring area. The more regional view presented by the SKYLAB photography suggests that the well-defined basin margin fault southwest of Battle Mountain (BM) and bounding the northwestern side of Buffalo Valley would, if projected southward, intersect the northeast trends in the vicinity of Buffalo Valley Hot Springs at (bv).

It is apparent that most of the well-defined structures present in figure 3 are basin-and-range faults and in many cases are parallel to sub-parallel to basin margin faults which offset unconsolidated valley fill deposits. The most difficult problem arising from analysis of such high quality synoptic data is to become overwhelmed by the majority of linear features. Because it is difficult to rationalize the existence of so many potential alignments of features on the scale presented in figure 3, a data format such as LANDSAT imagery becomes useful in decreasing the "noise" provided to the interpreter using high resolution photographic data over such a large area. 
AEROMAGNETIC DATA INTERPRETATION

A generalized contour plot of total magnetic intensity was prepared from U. S. Geological Survey open-file aeromagnetic maps (1:62,500 scale). These data were reduced to $1: 250,000$ scale by using a Map-0-Graph optical enlarger. The baseline gamma setting for each of the 8 aeromagnetic surveys, which cover the Winnemucca AMS Sheet, was different and therefore only the general magnetic intensity contour trends could be represented at the 1:250,000 scale.

The most prominent feature represented on the generalized aeromagnetic map (fig. 4, reduced from 1:250,000) is the expression of the NNW trending positive magnetic high, which closely corresponds with the trend of the Oregon-Nevada Lineament in this area. The close spacial association suggests that the magnetic anonaly is related to the feeder dikes that produced Miocene lava flows and domes (Stewart and others, 1975).

The anomaly is disrupted in several areas, most conspicuously at $A$ in figure 4 where the disruption in the aeromagnetic trend corresponds to the northeast trending Crescent Valley fault. Another area of disruption of the anomaly occurs at B. Again the area coincides with northeast trending faults and a prominent LANDSAT lineament. The offset in the aeromagnetic anomaly in both areas is apparently the result of down-dropping of the highly magnetic rocks of the feeder dikes (Stewart and others, 1975).

The disruption of the aeromagnetic anomaly by cross-cutting northeast trending faults and close association with observed northeast trending LANDSAT 1ineaments suggests that the movement on the northeast trending structures is postMiocene, if a Miocene age for the development of the Oregon-Nevada Lineament is accepted as suggested by Stewart and others (1975). Movement on the northeast trending structures appears to be normal faulting, as indicated by the apparent down-dropping of the feeder dikes. As mentioned earlier, interpretation of the LANDSAT imagery suggests that the NW trending Oregon-Nevada Lineament is younger 


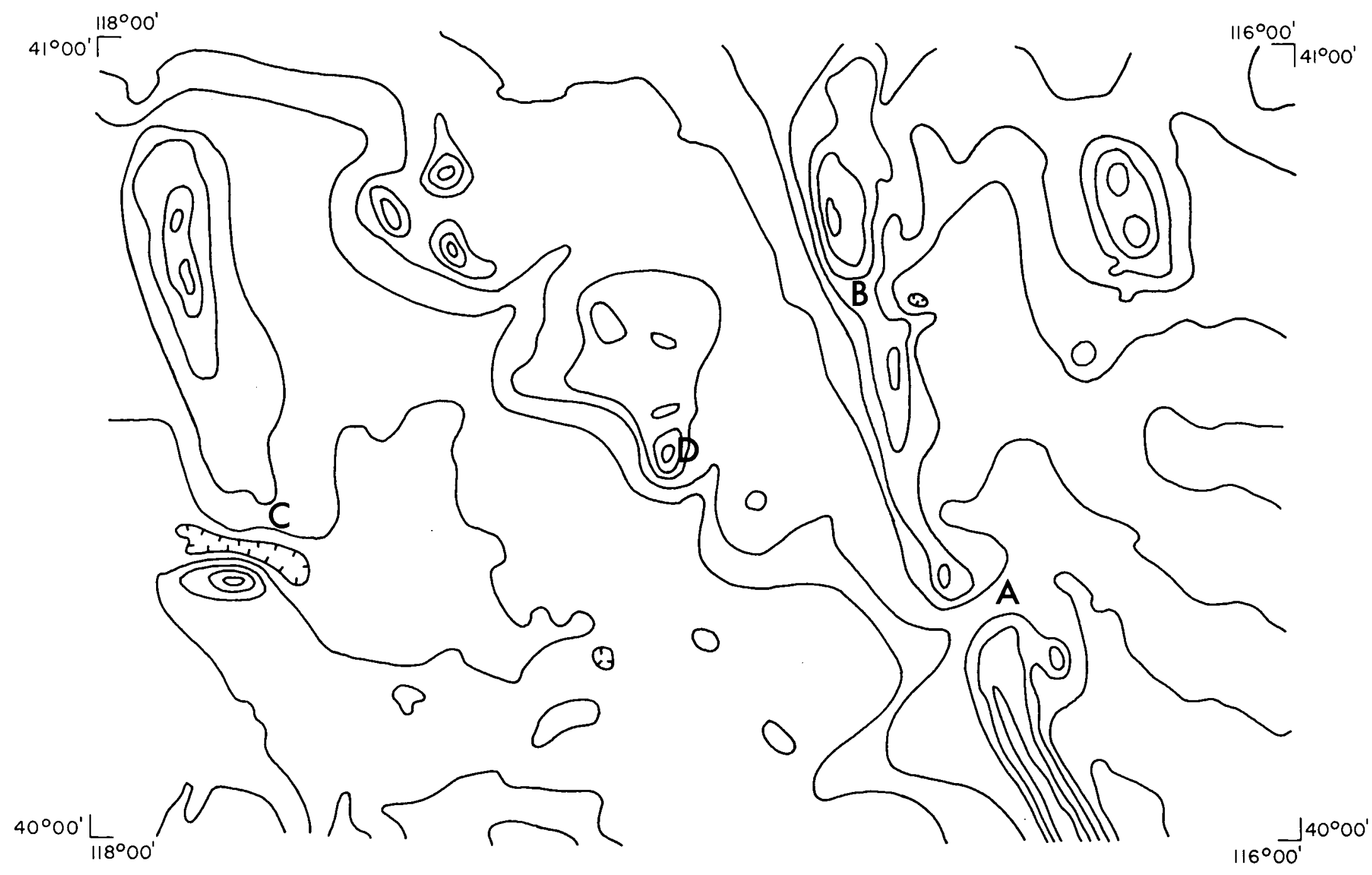

FIGURE 4. Generalized total-intensity aeromagnetic map of the Winnemucca AMS sheet, prepared from U. S. Geological Survey open-file aeromagnetic maps at 1:62,500. 
than the Midas system since it obliterates the surface manifestation of the northeast trends north of Battle Mountain.

In the western portion of figure 4 (area $\mathrm{C}$ ) a north-northeast trending positive magnetic anomaly is disrupted by an east-west trending negative anomaly. The circular positive high to the south of the low is associated with granitic intrusive rock of Granite Mountain. The intrusive contact is spacially associated with a northeast trending LANDSAT lineament that coincides with the interruption of this magnetic anomaly.

An intense positive aeromagnetic anomaly on the south side of Battle Mountain (D) appears to be associated with young basalt flows, which trend northeastsouthwest along the west side of Buffalo Valley. There is a discrepancy in the age of basalts by $\mathrm{K}-\mathrm{Rb}$ dating techniques and this discrepancy will be discussed in detail in the site specific section.

Interpretation of the total intensity magnetic anomalies indicates a direct correlation between the segments of the through-going positive anomaly, which appears to be associated with the Oregon-Nevada Lineament, and the northeast trends associated with the Midas Trench system. The major LANDSAT lineaments, which Rowan and Wetlaufer (1975) named Midas, are located north of the Winnemucca AMS Sheet and surface expression of en echelon structures in the Winnemucca AMS Sheet are: 1) the Crescent Valley fault; 2) the Whirlwind Valley fault; 3) faults associated with the southern edge of the Sheep Creek Range; and 4) the Argenta Rim.

\section{GRAVITY DATA INTERPRETATION}

Comparison of regional gravity with LANDSAT lineaments on a statewide scale (fig. 5) does not show any distinct correlation. This lack of correlation is probably due to the influence of the basin-and-range structure obscuring the crustal configuration of older lineaments. There is an increase (less negative) 


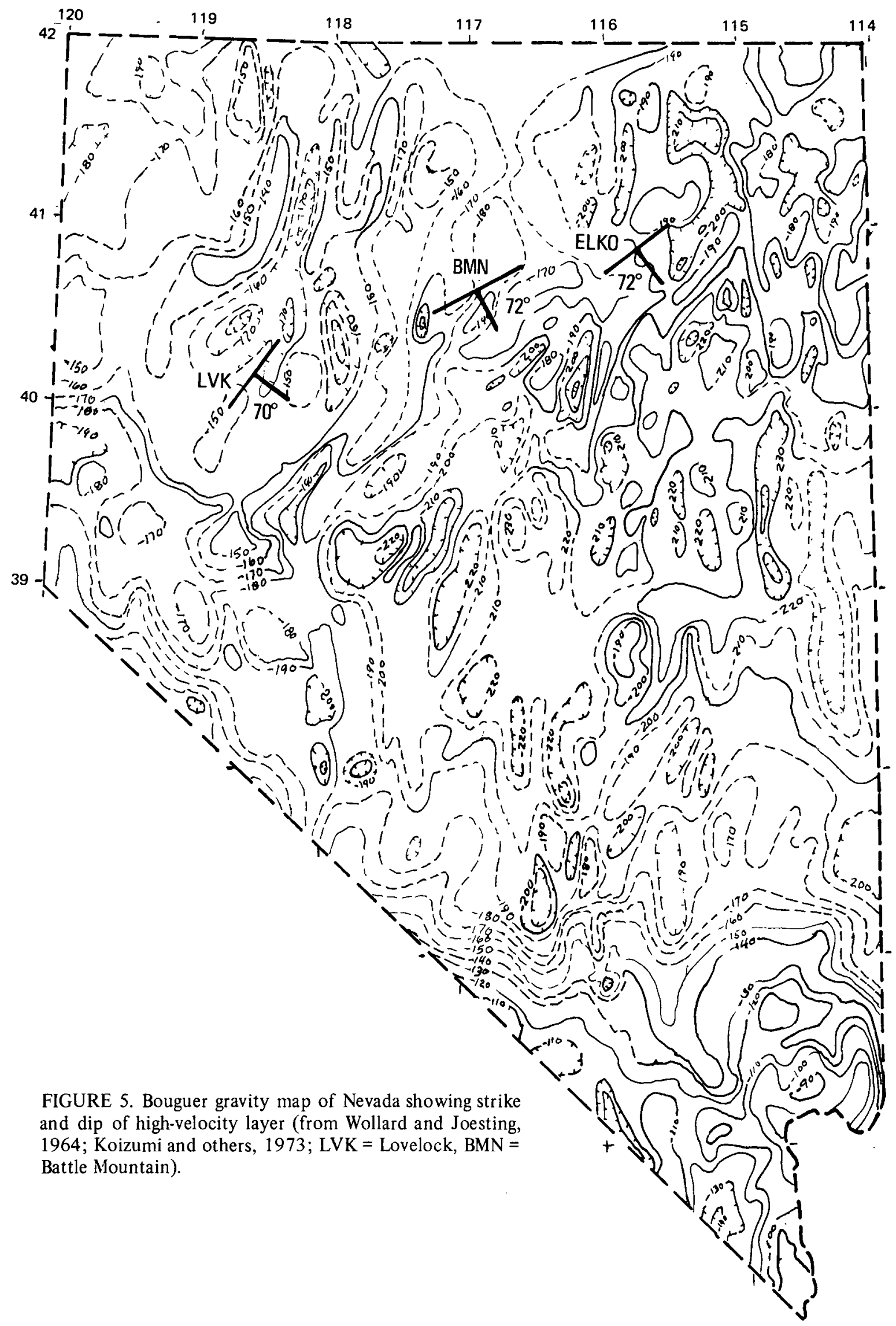


in the Bouguer gravity from the center portion of the state to the northwest. Typically, values less than -200 milligals are found southeast of a line which extends from the northwest corner of the state to longitude $118.5^{\circ}$, latitude $39.5^{\circ}$. 'To better show this decrease in gravity, a filtered gravity map (fig. 6) was prepared from Wollard and Joesting (1964) Bouguer Gravity Anomaly Map of the United States (West Half, 1:2,500,000). A 20-mile (34 km) grid was superimposed on the Bouguer gravity anomaly map and average values were measured for each grid. This was contoured and the resulting map (fig. 6) shows the regional gravity patterns and subdues the influence of basin-and-range structure. The marked increase in gravity to the northwest can be more clearly discerned.

A marked increase in gravity can also be seen in southern Nevada across an east-west zone where the average Bouguer gravity increases from -190 to -120 . The significance of this as a crustal boundary is discussed by Eaton (1975). The strike and dip of the high-velocity lithospheric plate interpreted by Koizumi and others (1973) as being a paleosubduction zone under northern Nevada is shown in figure 5. The high-velocity layer has a northeast strike at Battle Mountain and Elko (N60E and N45E, respectively). The strike of the plate is altered to a more northerly direction (N32E) near Lovelock, but maintains a similar dip. The variation in azimuth of the high-velocity layer in the Lovelock area may be due to disruption and rotation of the layer between the Walker Lane and Rye Patch lineaments. Since no further information is available at the present time, the hypothesis regarding the variation in azimuth of the highvelocity layer can only be conjecture. Work underway by Priestley and Cook may shed more light on the significance of this crustal anomaly (Keith Priestley, personal commun. 1978).

An analysis of gravity linears was prepared by using Erwin's (1974) Bouguer Gravity Map of Nevada, Winnemucca Sheet. A reduction of Erwin's (1974) map is shown in figure 7. Initially, many different gravity trends appear. However, 


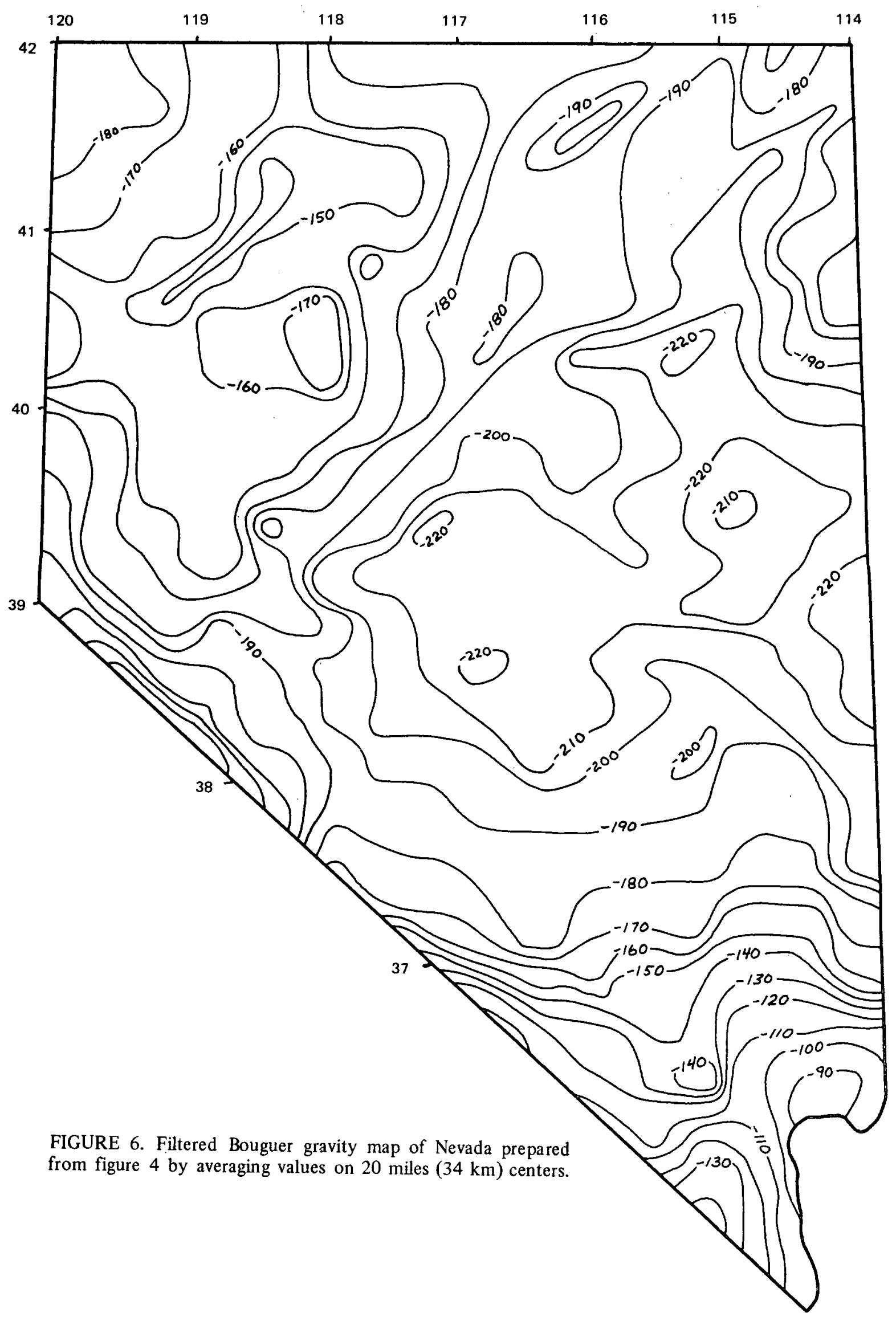




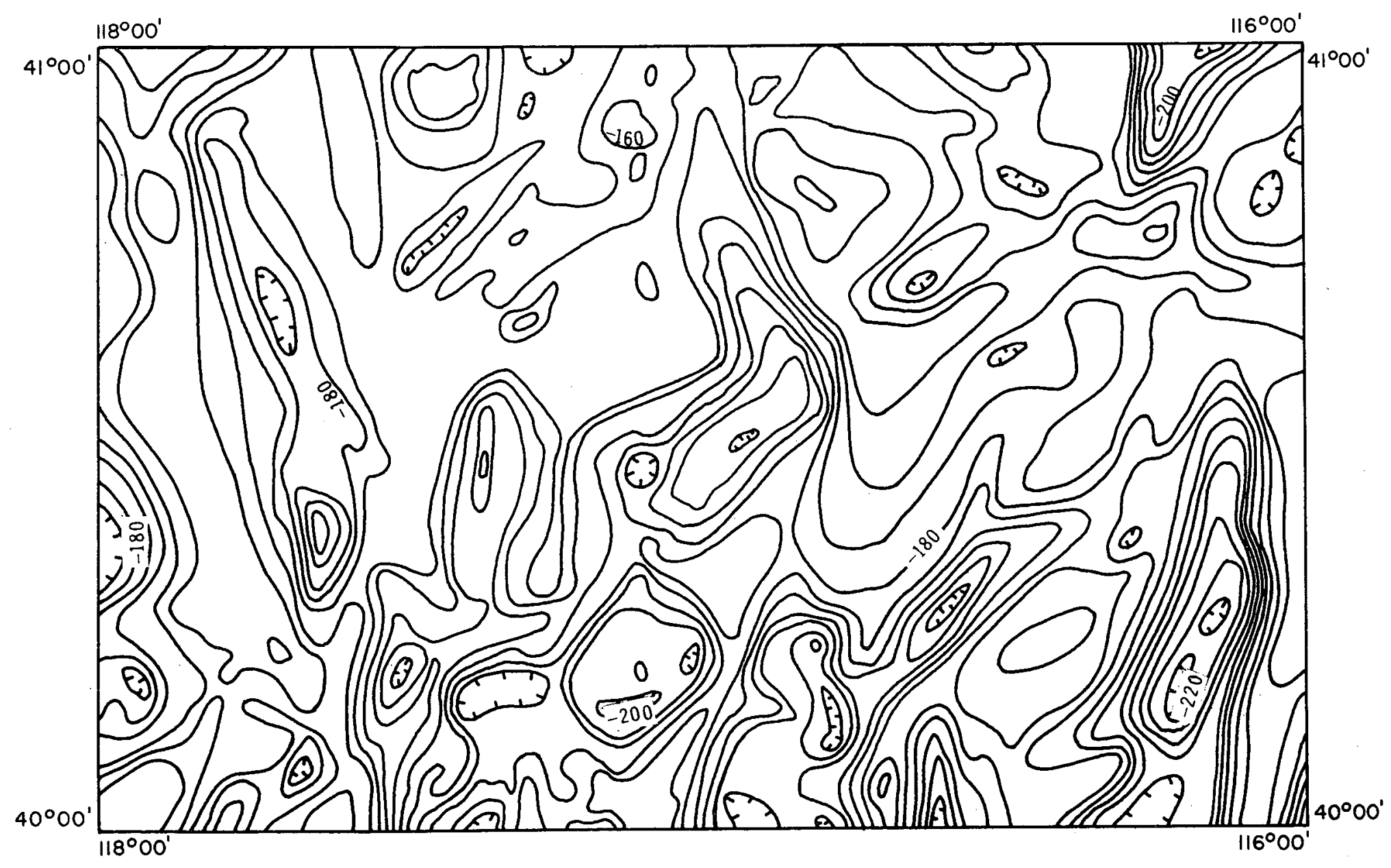

FIGURE 7. Bouguer gravity map of the Winnemucca AMS sheet, after Erwin, 1974. 
using the method of Robinson (1970) and by placing lines through high and low contour closures, the resulting gravity linears fall within two well marked trends.

The predominant directions are $\mathrm{N} 25 \mathrm{~W}$ and N35E. The northeast trends correspond with lineaments mapped from other data bases (LANDSAT and SKYLAB) and correspond with directions associated with the Midas Trench system. The next most pervasive trend identified in the gravity map is $\mathrm{N} 25 \mathrm{~W}$. This direction does not correspond directly with other northwest trends in other data formats. It may be associated with the N3OW maxima of LANDSAT lineaments of northern Nevada. A one-to-one correlation between surface features (LANDSAT lineaments) and subsurface features represented by gravity contours would not be expected.

COMPARISON OF LINEAMENT TRENDS

Frequency plots were used to compare lineament trends from the various photographic products and geophysical data. The frequency plots were produced to represent the percent cumulative length of lineaments. This method, it was felt, represented the lineament trends better than the percent of the number of lineaments. For example, a through going, well marked continuous lineament would have a smaller value if plotted as percent of total number of lineaments than a lineament that is composed of segments with similar trends.

A comparison of the lineaments mapped from the same source (LANDSAT) at two different scales and areas of coverage shows some variation in the trend of lineaments. As shown in figure 8, predominant trends for northern Nevada are N35E, N35W, N50E and with a minor north-south trend at N20E. Within the area of the Winnemucca AMS Sheet (fig. 9) the predominant trends are N67E and N52E. The N52E trend is consistent with a similar trend within the large scale northern Nevada LANDSAT analysis. All other trends within the area of the Winnemucca AMS Sheet are represented to some degree on the frequency plot for the entire northern Nevada area with the exception of the N35W trend (fig. 8), which represents the 
19.

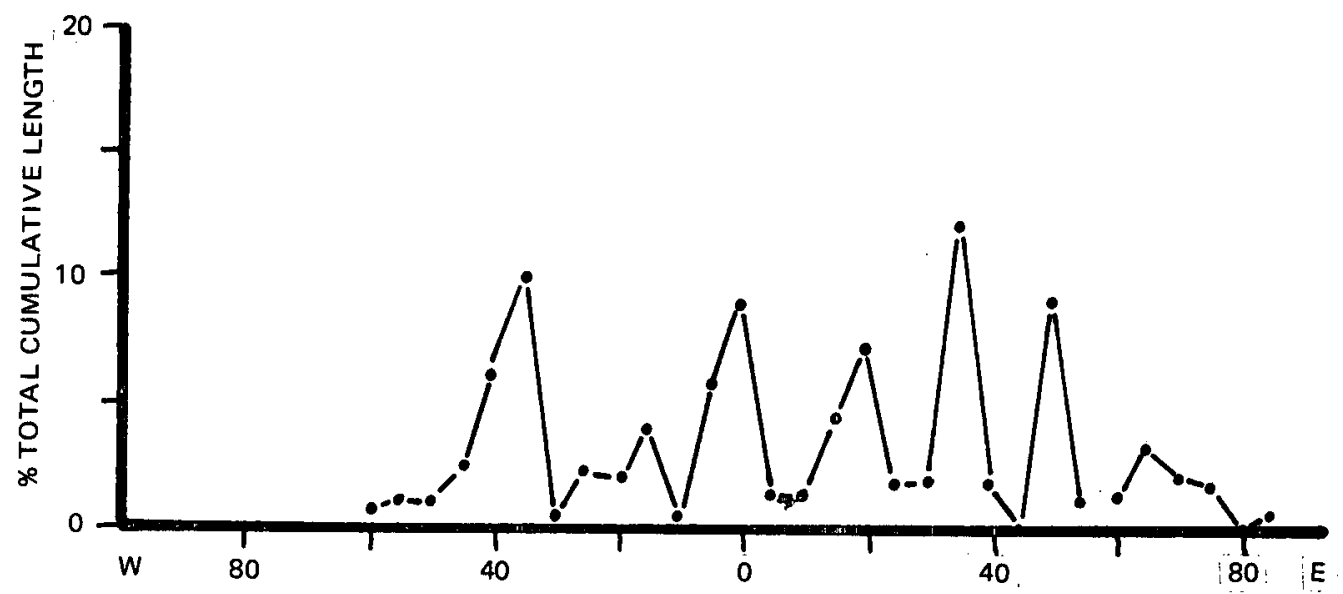

FIGURE 8. Frequency plot of LANDSAT lineaments of northern Nevada. 
Wa1ker Lane and the N67E trend (fig. 9) which is not apparent in the northern Nevada analysis. The N67E trend is probably genetically related to the structures in the area of Beowawe. Figure 10 is a frequency plot of the Beowawe area from a generalized geologic map of the Whirlwind Valley area (fig. 5, Wollenberg and others, 1975). It is apparent that the N67E trend is associated with faulting in the Beowawe area. There is a strong ENE trend in figure 10 which culminates with a N75E orientation. The similarities in trends $\left( \pm 05^{\circ}\right)$ between figures 9 and 10 at approximately N70E are probably due to similar structures.

Interpretation of SKYLAB S190-B photography at 1:250,000 scale produced a lineament map which has been reduced and generalized in figure 3. By inspection, it is apparent that strong NW trends are absent within the area. The NNW trend is related to the Oregon-Nevada Lineament which even at this scale and area of coverage $(1: 712,500$ and $4,225 \mathrm{sq}$. mi., respectively) can be discerned.

A frequency plot of distribution of lineament and fault trends for the area covered by the SKYLAB photography (fig. 3) was made. Plots of basins-and-range frontal faults indicated that trends ranged from NNW through NE (N15W through $\mathrm{N} 65 \mathrm{E})$. It was interesting to note that a $\mathrm{NE}$ trend was the major trend indicated within the area. A frequency plot of structures that could not be related to basin-and-range normal faulting showed that a more easterly trend (N7OE) was predominant and northerly trends (N5W-N1OE) were the next most abundant. The more northerly trends are probably associated with frontal fault activity that has affected the bedrock areas of the ranges and was not considered as basin and range frontal faulting.

The spatial relationships of interpreted LANDSAT and SKYLAB lineaments and Cenozoic normal faulting to sinter and/or travertine deposits, hot springs, opaline type cinnabar deposits, and recent volcanics are shown in figure 11. One of the most striking relationships is the alignment of recent volcanics 


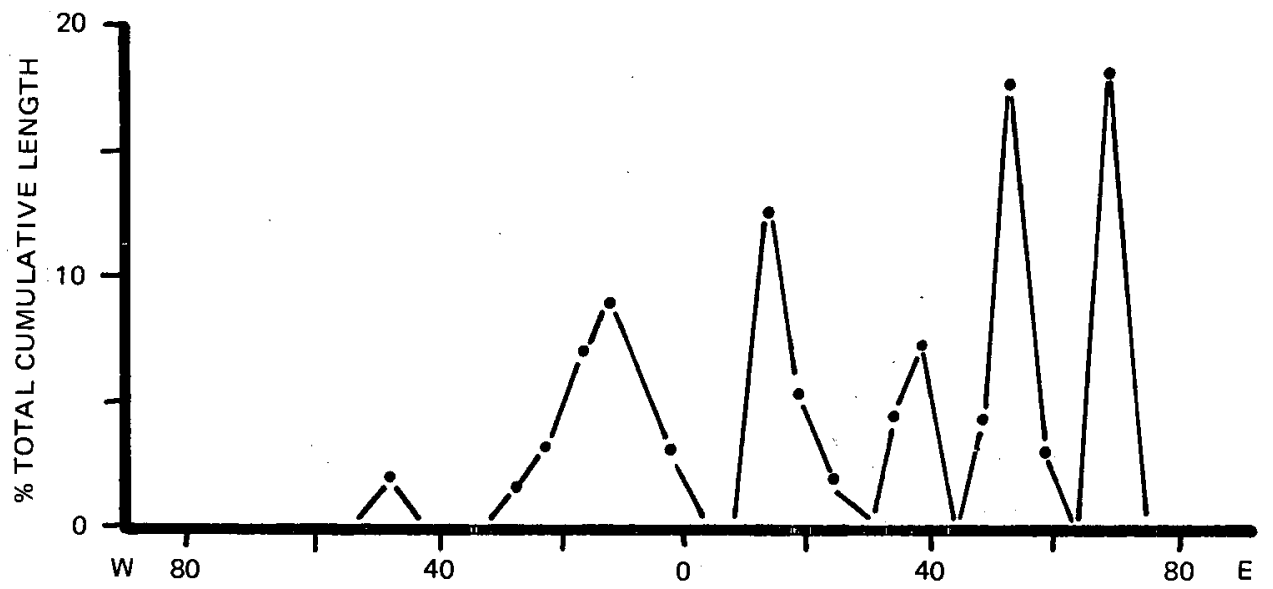

FIGURE 9. Frequency plot of LANDSAT lineaments within the Winnemucca AMS sheet.

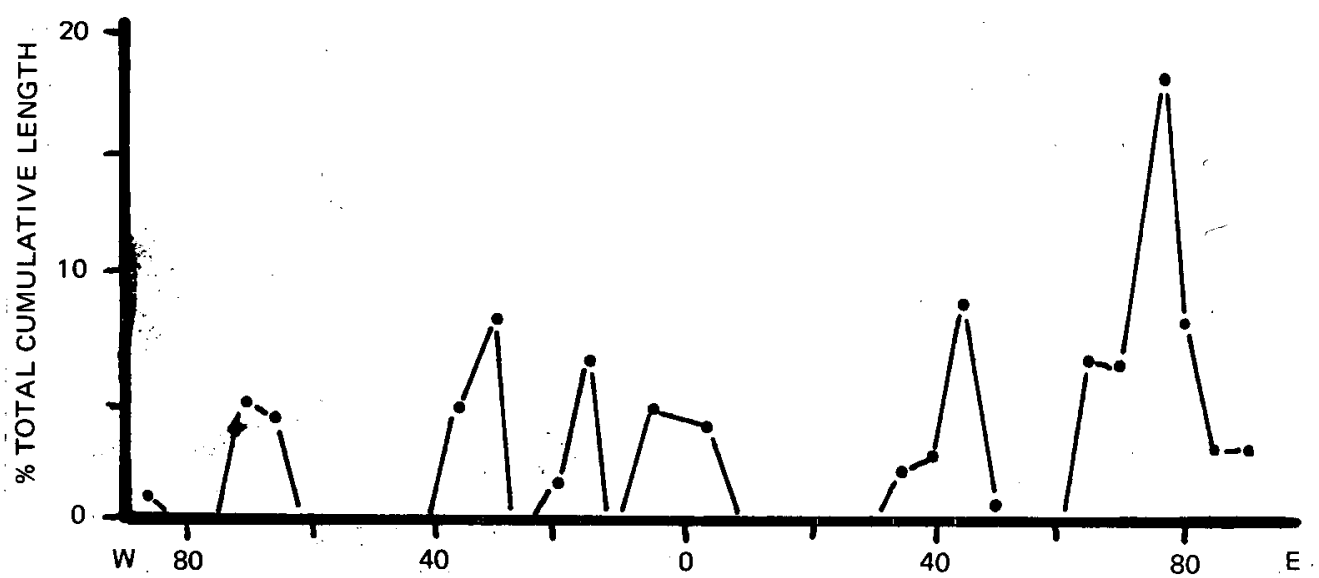

FIGURE 10. Frequency plot of fault trends in the Beowawe Geothermal Area. 


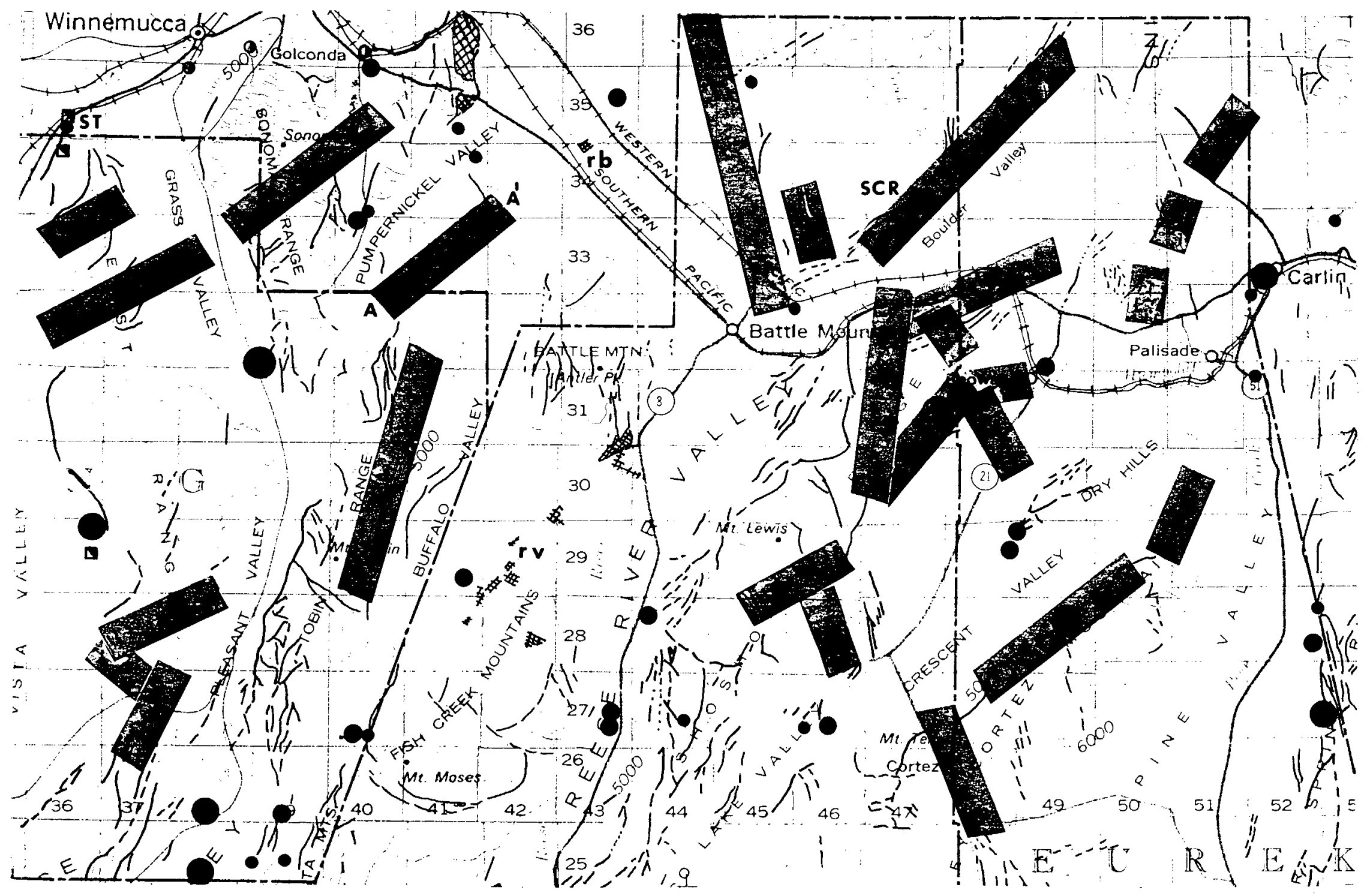

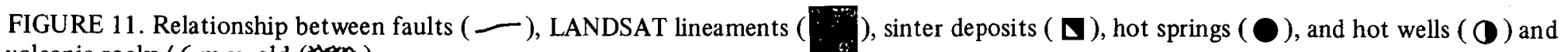
volcanic rocks ( 6 m.y. old ( ). 
(rv) in the west-central portion of the map area. This alignment has a preferred northeast trend, southwest along strike of a LANDSAT lineament which bounds the Sheep Creek Range (SCR) on the southeast. There appears to be an association between the areal distribution of recent volcanics in the northwestern portion of the map and LANDSAT lineaments. Two areas of recent volcanism at the northern boundary, east of Golconda, occur along the projected strike of the LANDSAT lineament which cuts the East and Sonoma Ranges. The second exposure of recent basalts ( $\mathrm{rb}$ ), protruding through valley fill deposits in the Humboldt River flood plain are aligned along the projected trend of the LANDSAT lineament which coincides with the frontal faults on the south side of Buffalo Mountain (A-A').

Sinter deposits representing ancient hot spring activity are associated with basin-and-range normal faults. Two sinter terraces (st) occur along the frontal fault flanking the westside of the East Range. The only other known occurrence of sinter representing previous hot spring activity is located along the strike of a northeast trending fault which is now the site of Kyle Hot Springs. The association and location of the sinter deposit is described in the site specific section of the Kyle Hot Springs area.

The spatial relationship between probable older hot springs or hydrothermal systems as manifested by opaline type cinnabar deposits is negative. Two opaline type cinnabar deposits located in the East Range are not associated with any mapped basin-and-range faults and they are not aligned along any interpreted LANDSAT lineaments. An interbedded type of cinnabar deposit located in the Tobin Range has fractures which are oriented $\mathrm{N} 60 \mathrm{E}$. The development of mercury mineralization along a fracture set that has a northeast-southeast trend would tend to indicate that fracturing may have been developed by tectonic activity associated with the Midas system. 
Evaluation of LANDSAT lineaments shows that 55 percent of those within the Winnemucca AMS Sheet correspond to faults shown on the geologic map of north-central Nevada (Stewart and Carlson, 1976). The remaining 45 percent of the lineaments fell into four categories: 1) those that corresponded to topographic features represented 13.5 percent; 2) 9 percent represented lithologic contacts; 3) and 9 percent corresponded with known faults less than 25 percent of their length. The fourth category consisted of thirteen percent or 3 lineaments that have no apparent topographic or geologic affiliations and must represent tonal variations on the LANDSAT imagery, which are other than geologic or topographic.

The spatial relationship between hot springs and faults mapped at 1:250,000 scale shows that of the seven hot springs with temperatures greater than $150^{\circ} \mathrm{F}$, four are associated with faults. Two of these are along faults of considerable linear extent and were interpreted as lineaments on the LANDSAT data. The Beowawe Hot Springs occurs along a lineament which corresponds to mapped faults. The other hot springs are located along the Cortez fault. Both lineaments as interpreted have similar trends $(\mathrm{N} 55-5)$.

Three hot spring areas $\left(>150^{\circ} \mathrm{F}\right.$ ) apparently are not associated with either mapped faults or lineaments. Two are in Dixie Valley and the other is near Carlin. The two springs in Dixie Valley however, may be associated with a northeast trend that includes Buffalo Valley Hot Springs, areally associated recent volcanics, and two warm springs northeast of the town of Battle Mountain that are coincident with the southeastern extent of a N45E LANDSAT lineament. There appears to be an ill-defined broad zone containing hot spring activity and recent volcanics in the central and southeastern portions of figure 11 that may be the expression of the well marked LANDSAT lineament at the southeastern side of the Sheep Creek Range. 
As described earlier the northwest trending LANDSAT lineament that intersects the northeast trending fault at Beowawe Hot Springs may be associated with hot springs at Hot Springs Point and along the Cortez fault. This alignment may correspond with the general trend of the Oregon-Nevada Linement.

SITE SPECIFIC STUDIES

\section{LEACH HOT SPRINGS}

Leach Hot Springs is in Pershing County approximately 28 miles $(45 \mathrm{~km})$ south of Winnemucca, Nevada, in Grass Valley. The spring area is easily accessible by gravel road. The springs are at the base of a NNE trending fault scarp, near the east side of the valley.

Lithologies exposed in the area range from consolidated rocks of Paleozoic age to unconsolidated alluvial and colluvial deposits of late Pleistocene-Recent age. Paleozoic rocks include the Pumpernicke1 Formation, the Havallah Formation, the Koipato Group and China Mountain Formation (Tatlock, 1969). These rocks range in age from Pennsylvanian to Triassic. The older units are eugeosynclinal sedimentary rocks while those of intermediate age are slightly metamorphosed intermediate to silicic volcanics; the youngest pre-Tertiary rocks are chert, limestone, dolomite and argillite of the China Mountain Formation. Paleozoic and Mespzoic rocks are exposed within the uplifted block of the Sonoma Range east of the hot springs.

Tertiary consolidated rocks are represented by a small outcrop of Tertiary welded tuff approximately 2 miles $(3 \mathrm{~km}$ ) northeast of the spring. Basalt of unknown age crops out on the upthrown side of a fault .75 mile $(1.2 \mathrm{~km})$ southeast of the hot springs.

Unconsolidated to semi-consolidated sedimentary rocks ranging in age from late Tertiary to Holocene overlie the older more consolidated pre-Tertiary and Tertiary rocks. The older Tertiary rocks include claystone, mudstone, marl, 
tuffaceous sand, silicic ash and tuff. They have undergone moderate deformation as indicated by dips of as much as $30^{\circ}$.

Mid-Pleistocene to Holocene units include old gravel deposits, alluvium, and sinter deposits. The old gravel deposits form hilly exposures on the west flank of the Sonoma Range immediately east of the hot springs and possibly underlie the alluvium in the center part of the valley (Olmstead and others, 1975). The deposits consist of poorly consolidated boulders, gravels, sands, silts and clays in various admixtures. They have been only mildly deformed with gentle easterly dips in various localities.

The youngest sedimentary units included alluvium and main-stream chane1 deposits. These units are contemporaneous and consist of gravel, sand, silt, and clay. They are genera1ly unsorted and poorly bedded. East of the hot springs, alluvial deposits overlie pediment surfaces and are only a few meters thick; however, they thicken rapidly westward toward the axis of the valley.

Sinter deposits can be divided into two categories, old sinter and opaline sinter being deposited today. The old sinter is exposed on the eastern (upthrown) side of the fault, along which the thermal waters emerge, and is composed of dense chalcedony. It is commonly associated with silicified and kaolinized alluvium.

Faulting in the hot spring area does not appear to be more prevalent than in other portions of Grass Valley. However it is one of the few locations in which faulting along a NE trend breaks valley fill material. Through going NE trending faults in bedrock are common in the East Range northwest of Leach Hot Springs (Stewart and Carlson, 1976) and well marked lineaments are apparent on LANDSAT imagery (Reeves, person commun. 1977). Based on regional analysis of 1 ineaments, Leach Hot Springs appears to lie on an extension of the northeast trending Buffalo Mountain fault. If this structure is related to a deep-seated tectonic pattern as suggested by the regional lineament analysis of Rowen and 
Wetlaufer (1975) and this work, then some correlation between hot springs and major structural lineaments can be inferred.

Faults which offset or juxtapose Quaternary deposits are shown on figure 12. The north-south range front fault, which is relatively linear and separates bedrock from valley fill, becomes segmented and transposed westward into valley fill deposits about 3 miles NNE of the hot spring, near the mouth of Sheep Ranch Canyon. At this location the fault which now cuts older gravels and alluvium makes an arcuate SSE bend. At a point approximately 1.5 miles $(2.4 \mathrm{~km})$ northeast of the hot spring, the fault strike changes markedly to northeastsouthwest and continues as a well marked scarp (A, fig. 12) to the hot spring. Southwest of the hot spring the trace of the fault is obscured beneath alluvium. Along the projected strike approximately .4 miles $(600 \mathrm{~m})$ south, a spring issues forth (B) and prominent northeast trending cracks (C) in the young alluvium may represent the southerly continuation of the fault. Other faults with a similar northeast trend can be seen in the vicinity of D. A north trending basin-andrange normal fault is apparent at $\mathrm{E}$.

It is interesting to note that earlier interpretation of thermal infrared imagery of the Leach Hot Springs area by Quade and Trexler (1975) indicated a thermal anomaly along the fault scarp near the mouth of Sheep Ranch Canyon. At that time the positive correlation between geothermal activity and northeast trending structure was not realized. A northeast trending fault intersects the north-south trend of the range front fáult at this location and may be responsible for the thermal anomaly.

\section{BUFFALO VALLEY HOT SPRINGS}

Buffalo Valley is an endorheic basin located southwest of the town of Battle Mountain. It is bounded on the west by the Tobin Range which is composed of siliceous clastic rocks of Paleozoic age. To the east, the southern portion 


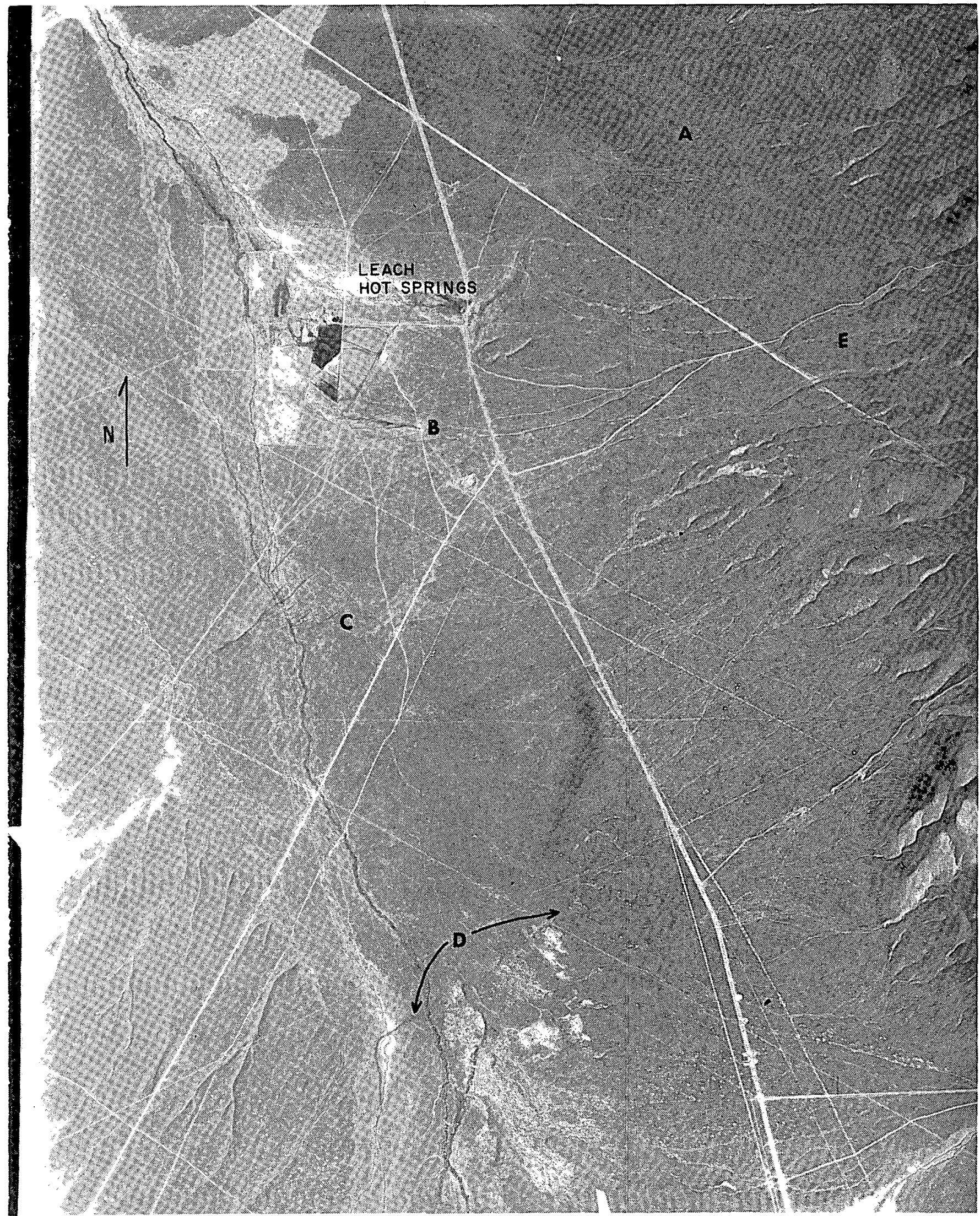

FIGURE 12. Low sun-angle aerial photograph of the Leach Hot Springs area showing northeast trending faults in alluvium. The hot springs are located along scarp A. Another spring B is located along strike between the main hot springs $\mathrm{A}$ and a series of northeast trending fractures at $\mathrm{C}$ (scale $1: 30,000$ ). 
of the valley is bounded by the northern Fish Creek Mountains. These mountains are predominantly Paleozoic clastic and Tertiary carbonate rocks overlain by ash-flow tuffs of Miocene age (McKee, 1970).

Basalts extruded from vents along the southeast side of the valley form a chain of cinder cones. The distribution of the basalt, some located atop the Fish Creek Mountains, suggests that the volcanic event predated the uplifting of the range. The age of the basalts is in question. Mckee (1970) suggests a Pliocene or early Pleistocene age based on K-Ar dating (ca. $3 \mathrm{~m} . \mathrm{y}$. ). However a more recent data (Silberman, personal commun. 1976) by K-Ar method provides an age of $1.35 \pm 0.15 \mathrm{~m} . \mathrm{y}$. ; considering the morphology of the cinder cones it is believed the $1.3 \mathrm{~m} \cdot \mathrm{y}$. date is probably correct. This is further substantiated by the thin alluvial cover which overlies basalt penetrated in two test holes at depths of 29.9 and 21.0 m (O1msted and others, 1975, p. 232). They suggested a slow rate of deposition along the the east side of Buffalo Valley based on the $3 \mathrm{~m} \cdot \mathrm{y}$. date. If the younger date $(1.3 \mathrm{~m} \cdot \mathrm{y} \cdot)$ is assumed to be correct, then rates of deposition would probably be normal for this thickness of alluvial material.

The unconsolidated valley fill consists of alluvium, lacustrine deposits, playa deposits, and spring deposits of early Pleistocene to Holocene age. Periodically during the late Pleistocene, lakes occupied the valley. Shorelines left from these lakes are conspicuous around the valley margin. Playa deposits overlie lake deposits and consist mainly of silt and clay. Abundant salts exist in the near-surface playa deposits due to evaporation of ground water. Spring deposits consist of clay, silt and sand. These deposits are predominanty calcareous, with siliceous sinter being absent.

Buffalo Valley is an asymmetrical graben closed at its southern end. North trending basin-and-range faults bound the valley on the west at the base of the 
Tobin Range. Several faults diverge from this northerly trend and become oriented northeasterly around the central playa area north of latitude $40^{\circ} 25^{\prime}$ (Wollenberg and others, 1975). Basin bounding normal faults are not as conspicuous on the east.

A northeast trending fault visible in figure 13 ( $\left.B-B^{\prime}\right)$ cuts recent basalt. A tonal variation in the alluvium is apparent along the southwest extension of the fault. Wollenberg and others (1975) mapped a concealed fault continuing from the surface-manifested scarp through Buffalo Valley Hot Springs. The northeast alignment of cinder cones ( $A-A^{\prime}$ ) suggests that they were extruded along a basin-and-range fault or fault zone (01mstead and others, 1975). The location of the hot springs and a circumalluviated basalt cinder cone at $C$ are also aligned along a similar northeast-southwest trend.

\section{KYLE HOT SPRINGS}

Kyle Hot Springs is located in Buena Vista Valley about 30 miles $(50 \mathrm{~km})$ south of Imlay, a small settlement on Interstate 80 . The spring area is on the east side of Buena Vista Valley in a similar position, relative to the valley axis, as Leach Hot Springs.

Basement rocks in the East Range are Paleozoic eugeosynclinal facies, which are allochthonous. The oldest rocks are the Ordovician Valmy Formation, which consists of chert, shale, quartzite, greenstone, and minor amounts of limestone. Younger Paleozoic eugeosynclinal rocks of Mississippian through Permian age have been thrusted over the Valmy Formation above the Golconda thrust (Stewart and Car1son, 1976). These rocks include pillow lavas, coarse volcanic breccias, chert, argillite, shale, sandstone, minor limestone of the Havallah sequence, and undifferentiated rocks of Mississippian age.

Mesozoic rocks are represented by plutonic leucogranite and sedimentary rocks ranging from limestone to conglomerate in composition. Rocks of Tertiary age are intrusives of quartz monzonite to granodiorite in composition and extrusive rocks ranging from basalt to andesite. 


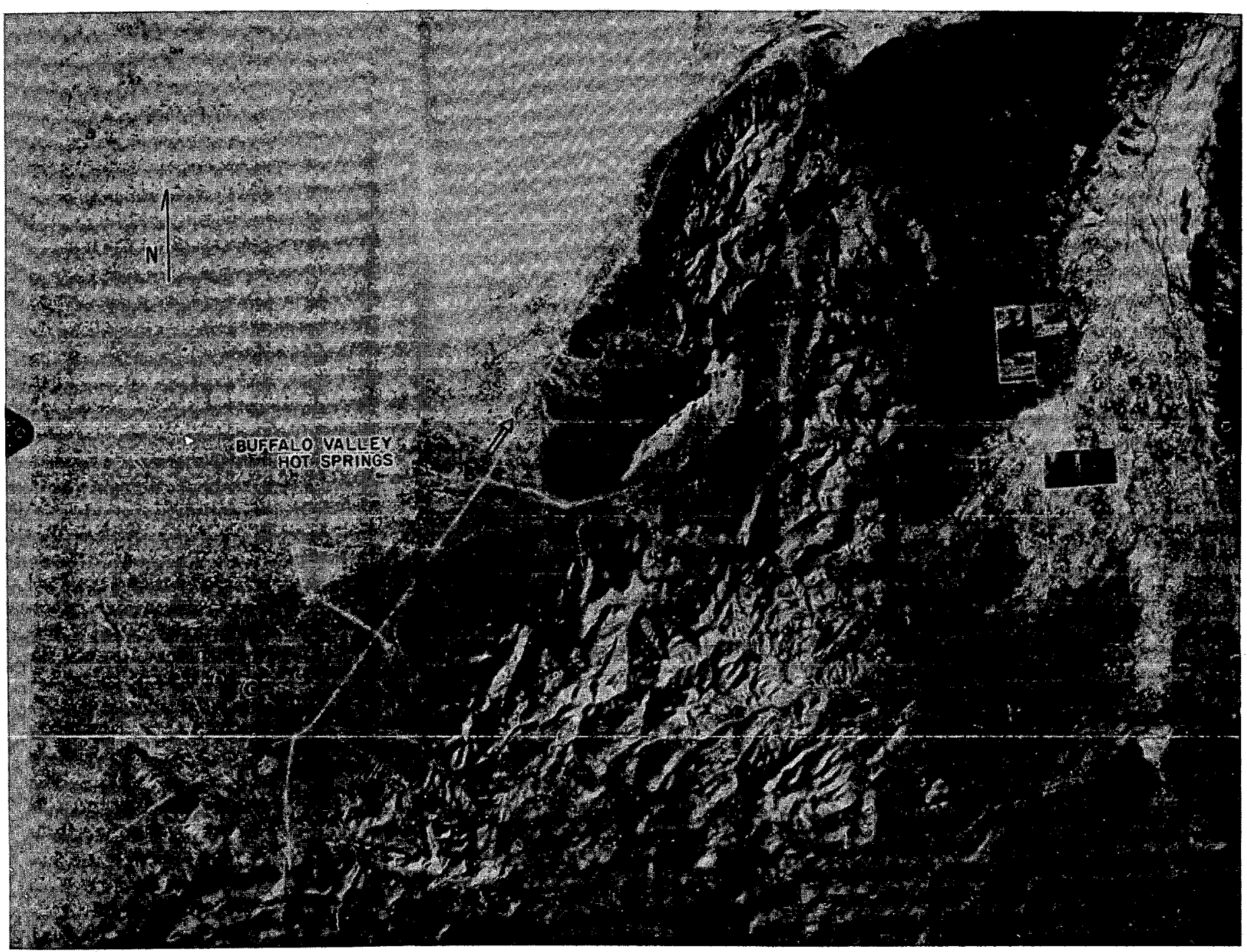

FIG̈URE 13. Low sun-angle aerial photograph of Buffalo Valley showing the distribution of Quatemary basaltic cinder cones. Trend $A-A^{\prime}$ is continuous with the regional northeast trend of the Midas Trench system. A fault cuts the basalts and alluvium between $B-B^{\prime}$ and has a similar trend to $A-A^{\prime}$. The circumalluviated basalt outcrops at $C$ and the location of Buffalo Valley Hot Springs appear to align along a similar northeast trend (scale 1:120,000). 
Semiconsolidated and unconsolidated clastic material of late Tertiary and Quaternary age cover the pre-Tertiary rocks in Buena Vista Valley. These rocks thicken from the base of the East Range westward and attain a maximum thickness of 6,500 to 8,200 feet $(2-21 / 2 \mathrm{~km}$ ) (Erwin, 1974).

Faulting in the Kyle Hot Springs area is shown in figure 14 where a northwest trending fault segment $(A-B)$ parallels the range front. The fault becomes somewhat segmented at $B$ and makes an arcuate bend to the southwest and continues through the hot spring to $C$. Along the projected strike of the northeastsouthwest trending segment $(B-C)$ is an old, inactive spring mound which appears geometrically similar to the present active spring in the distribution of sinter.

Here again, as at Leach Hot Springs which is located in the valley immediately east of Buena Vista Valley, the hot springs occur along northeast oriented faults that cut older alluvium. The age of faulting in this area is apparently greater than 12,000 years B.P. since shorelines southwest of the spring area are not cut by the fault and evidence of the fault in recent stream channel deposits is not apparent. Measurement of fault scarp angles and the application of Wallace's (1977) criteria confirm that faulting along the scarp from which Kyle Hot Springs issues occurred more than 12,000 years B.P.

\section{BEOWAWE GEOTHERMAL AREA}

Located approximately 18 miles $(30 \mathrm{~km}$ ) east of the city of Battle Mountain, Nevada, the Beowawe geyser area occupies the southeast side of Whirlwind Valley. It is apparent by the conspicuous sinter terrace, which is 2,800 feet $(850 \mathrm{~m})$ long at the top, 4,000 feet $(1,200 \mathrm{~m})$ long at the base and 100 feet $(30 \mathrm{~m})$ wide at the crest. The terrace stands over 250 feet $(75 \mathrm{~m})$ high and is backed by the ENE-trending Malpais scarp (Osterling, 1962).

The oldest rocks exposed in the area of hot spring activity are Paleozoic eugeosynclinal facies (Ordovician, Vinini Fm.), which are allochthonous above the 


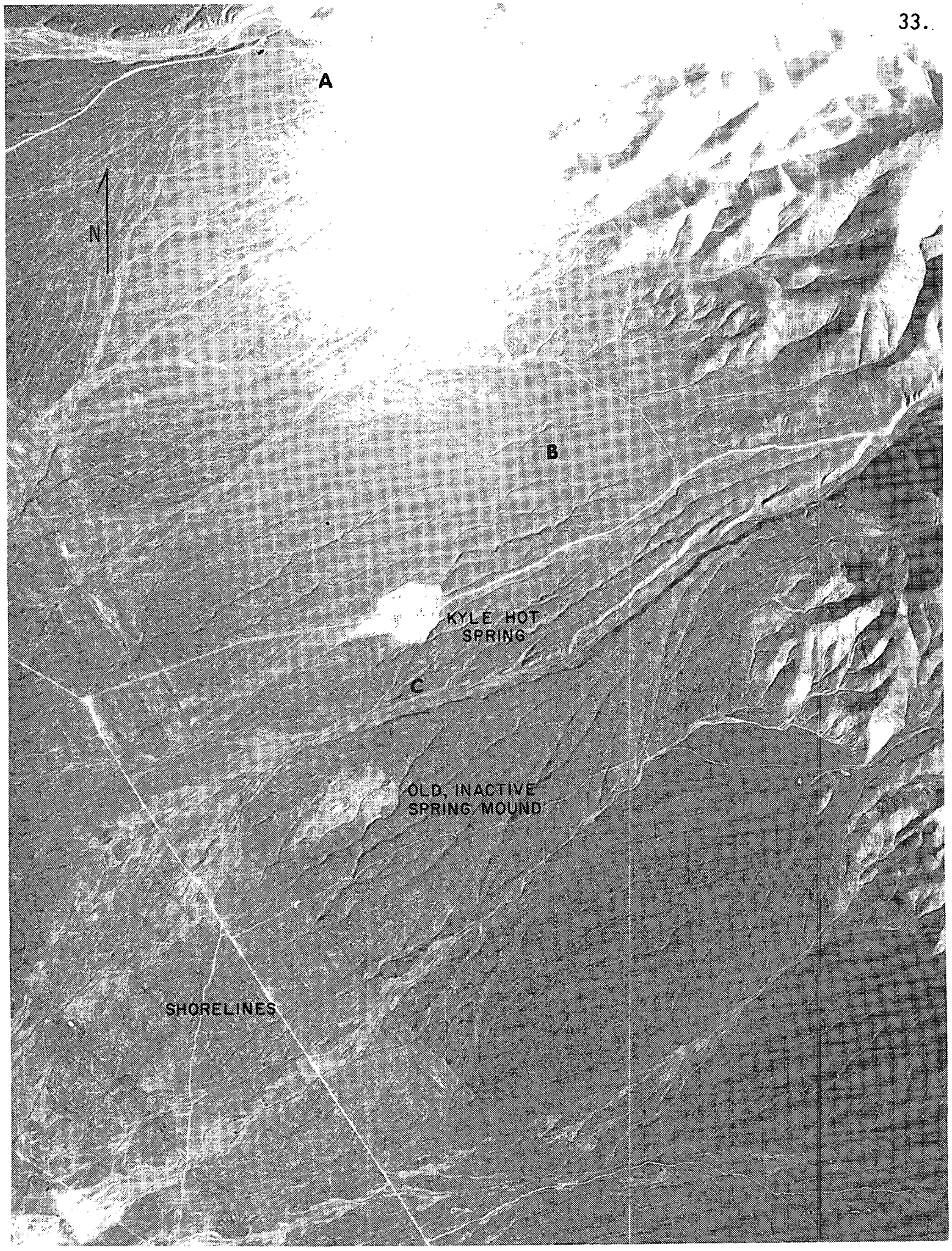

FIGURE 14. Low sun-angle aerial photograph of the Kyle Hot Springs area. Note fault A-B, trending north-northwest parallel to the range front. At B the fault bends southwest and continues to $\mathrm{C}$ (Kyle Hot Springs). Along the projected strike of this trend is an older, inactive spring mound (scale $1: 30,000$ ). 
Roberts Mountains thrust. Outcrops of the rocks are limited in distribution. Tertiary volcanic rocks of basaltic andesite composition comprise most of the bedrock in the area. Minor, later basalt extrusions cap the basaltic andesite to the southeast of the spring area atop the Malpais scarp (Osterling, 1960). Quaternary deposits in the area consist of alluvial deposits, alluvial fan deposits, landslide deposits and sinter. The sinter of the terrace is entirely opal and varies widely in texture and color.

Basin and range normal faulting predominates in the area of Beowawe Hot Springs. Variable and intersecting trends occur near the spring terrace. Small scale mapping by Osterling (1960) best exemplifies the complexity of the area. He mapped several cross-cutting faults trending northwesterly across the dominant ENE-trending Malpais scarp. Recurrent movement along the faults is suggested by a $50 \mathrm{ft} .(17 \mathrm{~m})$ scarp in the sinter terrace, which has dropped a portion of the terrace this amount in Recent times.

At larger scales, the complex and cross-cutting relationships between faults in the area can be identified. Figure 15 shows the Beowawe area at a scale of 1:120,000; the ENE-trending Malpais scarp (A-A') is sub-parallel to the Argenta $\operatorname{Rim}\left(B-B^{\prime}\right)$. Both features can be readily identified on LANDSAT imagery. The structural grain parallel to these two features can be distinguished as short linear breaks in the Tertiary volcanics throughout the area of figure 15 east of $\mathrm{C}-\mathrm{C}^{\prime}$. The ENE-trending grain is somewhat complicated and not readily apparent in Paleozoic rocks west of $\mathrm{C}^{-} \mathrm{C}^{\prime}$. A north-northwest trending lineament $\left(D^{-}-D^{\prime}\right)$ crosses the Malpais scarp east of the spring area. The lineament coincides with en echelon north-northwest trending faults, one of which crosses the scarp in the vicinity of the landslide (E).

More northwesterly trending lineaments are apparent in the vicinity of $\mathrm{F}$. Osterling (1960) inferred that two sets of faults with northwest trends extended from $F$ to the spring area. 


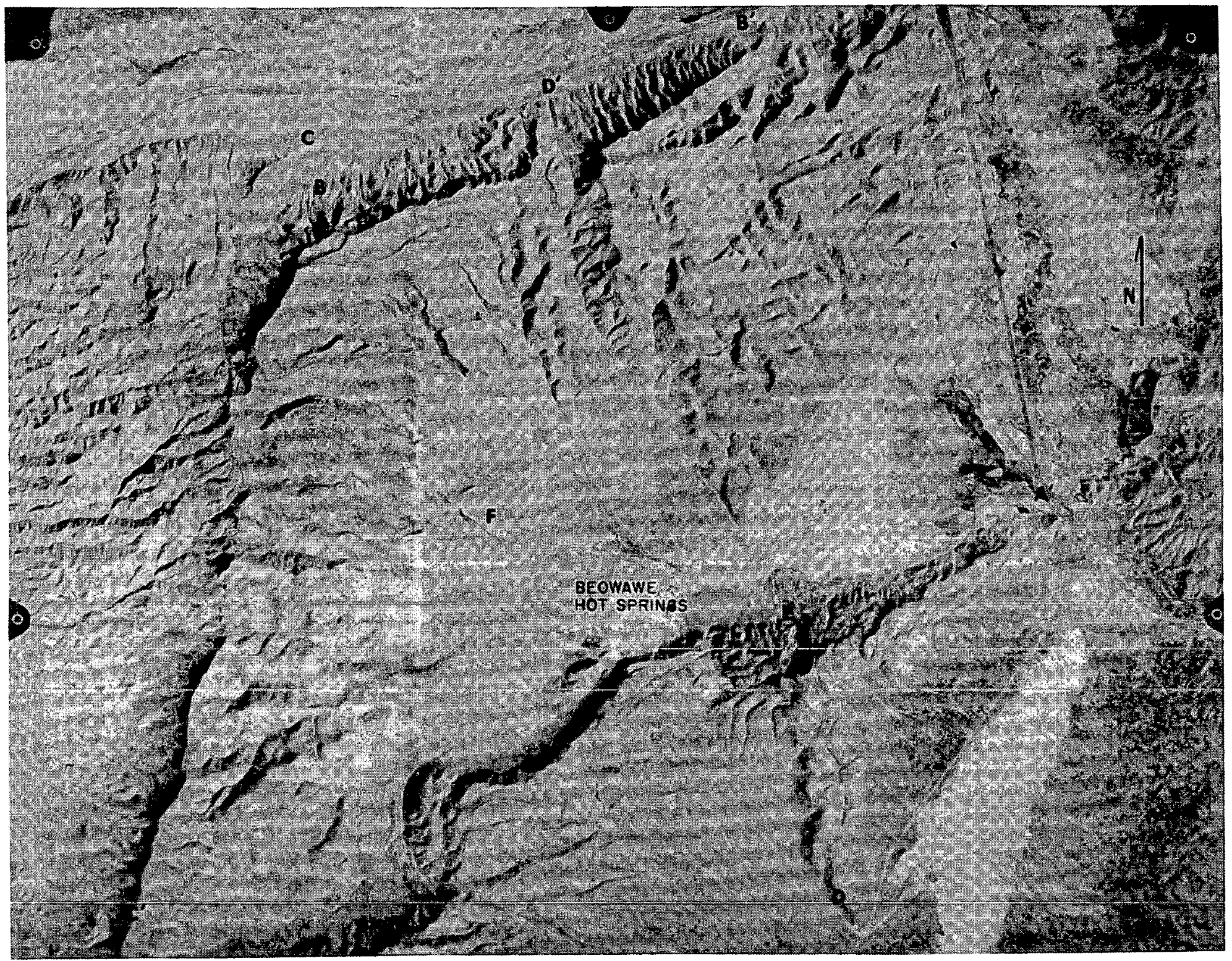

FIGURE 15. Low sun-angle photograph of the Beowawe area, scale 1:120,000 
The existence of Beowawe Hot Springs is undoubtedly related to faulting. It is interesting that the majority of spring activity is associated with ENEtrending faults. The intersection of north-northwest trending cross faults in all probability led to the fracturing of basement rocks, but it appears that the majority of hydrothermal activity is concentrated along the ENE-trending faults. 


\section{INTRODUCTION PHASE II}

The second phase of the study applied the lineament analys is techniques which proved most useful in delineating geothermal areas in typical basin-andrange structures to an area which contains a more complex structural setting. The area selected for the second phase was the Reno AMS Sheet. This area contains three tectonic subprovinces of diverse structural complexity: 1) the Sierra Nevada Front, 2) the Walker Lane and 3) the Basin and Range. In some areas one type of tectonic pattern is overprinted on another producing complex interrelationships.

High altitude (U-2) low sun-angle photography which proved most useful in site specific studies in the Winnemucca area were requested to support the second phase of the program but due to a DOE/DGE desision these data were not made available. This lack of superior quality medium to large scale low sunangle photographic coverage severely limited the detailed studies in some areas where alternate airphoto coverage was absent or of poor quality.

The original work statement for the second phase of the program was modified to include a task to determine the availability of geothermal data in Nevada. Results of this work have been reported in a separate document entitled, Summary Report of Availability of Geothermal Data for Potential Direct Heat Application in Nevada, DOE/DGE NVO/0671-1.

\section{GRAVITY AND AEROMAGNETIC LINEAMENTS OF THE RENO AMS SHEET}

Major lineaments defined by the complete Bouguer Gravity Map of Nevada, Reno Sheet (Erwin and Berg, 1977) fa11 within four trends. The dominant trend is northwest and probably represents the Walker Lane fabric. The next most dominant trend of gravity lineaments is north-northeast; this trend is closely allied with a singular northerly trend N05W. These trends are characteristic of the basin-and-range structure and the Sierran Block and may represent crustal control of the physiographic features apparent on the surface in this 
complex region. The three tectonic zones: 1) Sierra Nevada Front, 2) Walker Lane, and 3) Basin and Range were defined as areas which would be investigated as to the occurrence of geothermal anomalies associated with lineament concentrations or lineament intersections.

The influence of the Walker Lane on the deep-seated crustal fabric is interesting with respect to the alteration of gravity trends from directions which were noted in north-central Nevada. The pervasive nature of the structure as evidenced on the gravity map suggests that this zone plays a major roll in Tertiary structural development of the area. The termination, displacement and bending of many of the north-south trending ranges attests to the pervasiveness of the feature as it affects the physiography of western Nevada.

The least dominant trend noted in the lineament analysis of the gravity map is a northeast trend (N4OE-N6OE). These trends are probably related to the Midas Trench system which appears to be terminated by the Sierran Block. The disruption and segmenting of the northeast trends by the structures associated with the Walker Lane indicate that at depth the Walker Lane is more pervasive. This relationship is similar to that noted in our previous study near Battle Mountain where the Midas Trench system (NE trend) is interrupted by the OregonNevada Lineament (NW trend).

A 1 ineament analysis was performed on the Aeromagnetic Map of Nevada, Reno Sheet (NBMG Map 54, 1977). Most lineaments on the aeromagnetic map represent short discontinuous trends coincident with contour closures of 100 gammas or more. These trends are equally distributed in all azimuths and show no preferred orientation. A strong west-northwest trend represented by a several hundred gamma decrease in total magnetic intensity is apparent in the southwestern portion of the Reno Sheet. This trend is disrupted southwest of the Carson Sink and bends to the southwest. This zone of bending of the magnetic intensity contours may be the result of complications derived by the intersection of this trend with the northeast-southwest trends of the Midas Trench system. 
The decrease in total magnetic intensity is apparently related to the absence of young (Tertiary-Quaternary) volcanic rocks near the surface. Extensive exposures of Quaternary-Tertiary basalts are shown on the Geologic Map of Lyon, Douglas and Ormsby Counties, Nevada (Moore, 1969) in the Desert Mountains and northern Pine Nut Range. South of this area, mafic to intermediate volcanic rocks are less abundant. The dominant west-northwest lineament trend of magnetic intensity may be related to the areal distribution of the volcanic rocks and not to tectonic or structural controls.

A comparison of frequency distribution of gravity lineaments and magnetic lineaments failed to show any correlation. The lack of correlation is probably due to the perturbation of magnetic intensity by the presence of abundant intermediate to mafic extrusive rocks, which mask any indication of deep seated structura 1 controls.

\section{LANDSAT AND SKYLAB LINEAMENT ANALYS IS OF THE RENO AMS SHEET}

Lineament analysis was performed on portions of the study area using computer enhanced LANDSAT imagery and SKYLAB S-190B photography at 1:250,000 scale. Analysis was made of the entire Reno AMS Sheet using LANDSAT standard data products at 1:1,000,000 scale. Four frames of LANDSAT imagery which provide complete coverage of the study area were mosaicked to provide continuity of ineaments between frames.

Frequency plots of the lineament analyses are presented in figures 16 through 19. The same method, used previously, which represents percent cumulative length rather than the percent of total number of lineaments with similar trends was employed.

LANDSAT image $8 / 6 / 74$ which covers the northeast portion of the Reno AMS Sheet exhibits numerous bedrock lineaments of a few kilometers in length. Very few of the typical basin-and-range frontal faults were depicted on the imagery. The major trend mapped in this image is approximately N60W. Other major trends, 
representing greater than six percent of the sample, are N35W, N07W, N40E and an east-west orientation. Minor trends occur in the N45W, N22W and N57E orientations (fig. 16).

The N60W trend is not readily correlated with any known major 1 ineament systems in northern Nevada. Previous analysis of the $1: 1,000,000$ scale mosaic of Nevada did not show lineaments on a regional scale that had a strong N60W orientation. The trend of the Walker Lane as determined in the previous regional studies was approximately N35W. This agrees with the N35W orientation which is the second most predominant trend in this image.

The trends which are northerly (N07W) are undoubtedly related to en echelon basement structure related to basin-and-range faulting. Their variation from the typical NNE trend may be the result of perturbations caused by the many conflicting lineament patterns operating in the area. The variations noted in the analysis of this particular image may also be influenced by the Carson Sink which occupies approximately 30 percent of the scene within the Reno AMS Sheet, therefore biasing the sample.

The east-west trends have not been noted in previous analyses and their genetic relationship to the structural grain is vague. These trends may be conjugates of the NOTW trends in bedrock areas and represent older inactive corollaries to the basin-and-range structures.

Computer enhanced LANDSAT imagery covering the southwestern portion of the study area was obtained on 29 May 1976. Figure 17 is a frequency plot of the lineament analysis of that portion of the image which covers the Reno AMS Sheet. The major trend (N22E) is probably a resultant of the influence of the basin-and-range structures. The next most predominant trend is N18W. Lineaments with these trends are found in the western portion of the Reno AMS Sheet and are structures related to the Sierra Nevada Front. 


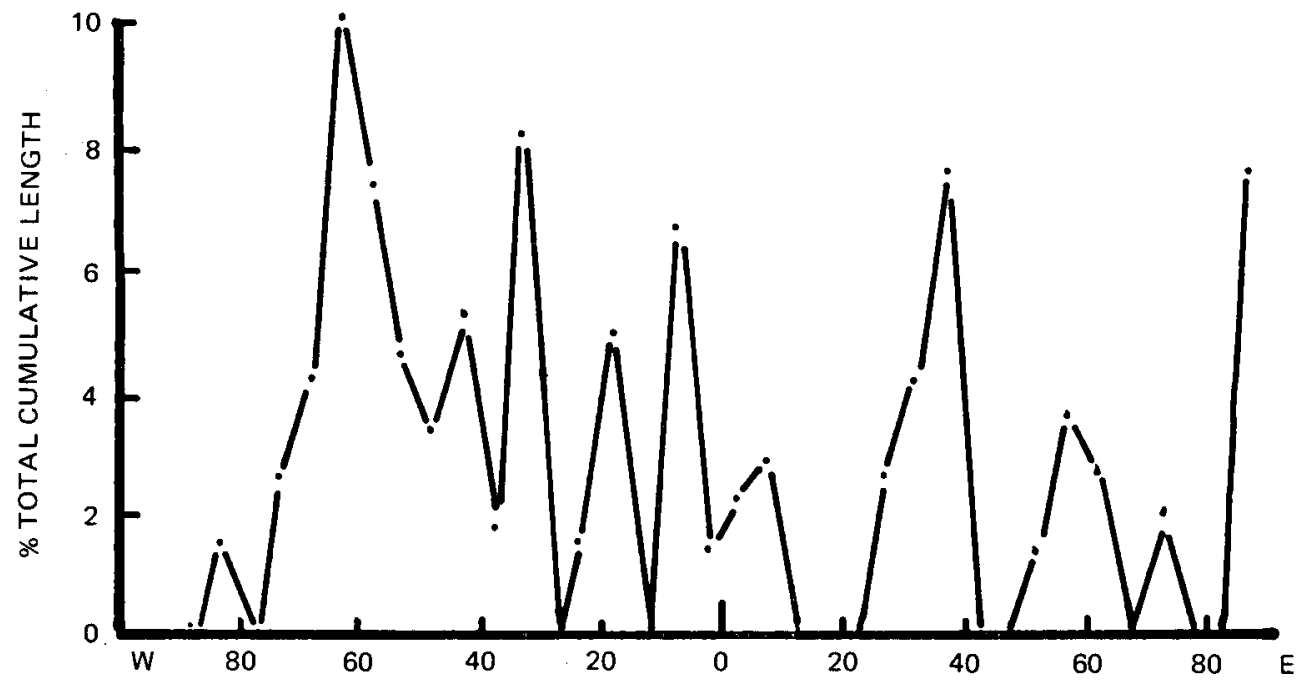

FIGURE 16. Frequency plot of lineaments from computer enhanced LANDSAT imagery of the northeast portion of the Reno AMS Sheet.

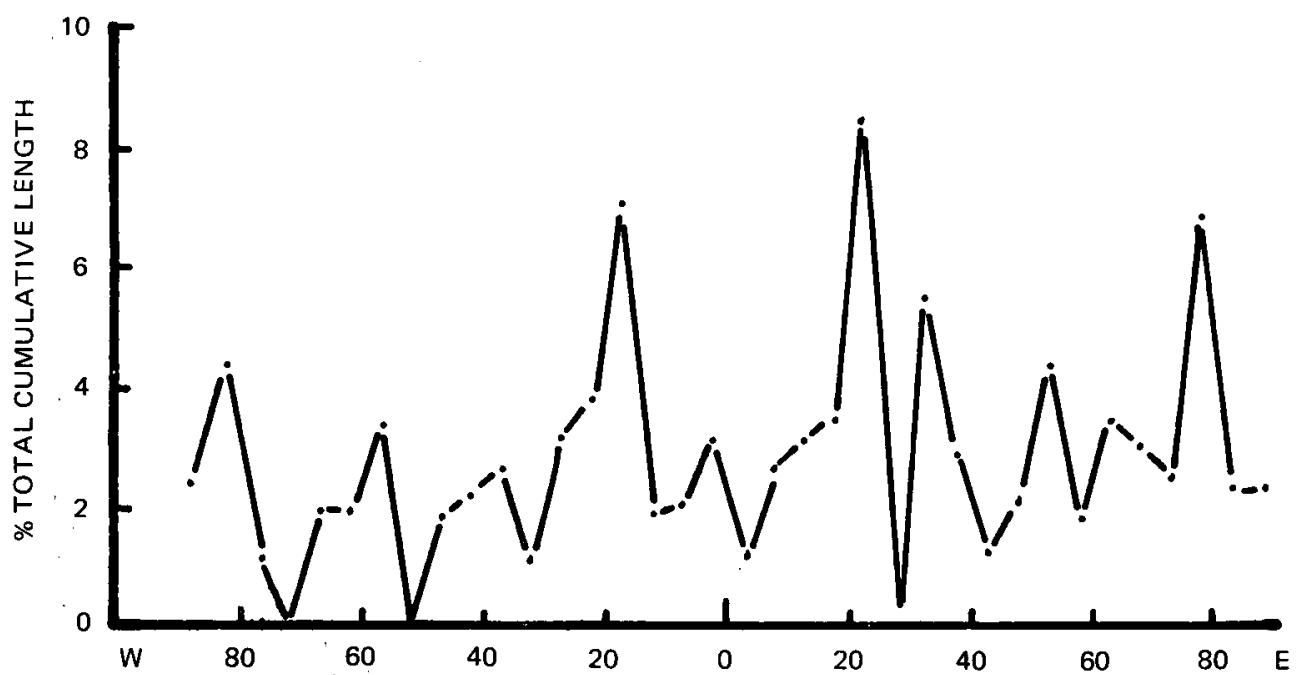

FIGURE 17. Frequency plot of lineaments from computer enhanced LANDSAT imagery of the southwest portion of the Reno AMS Sheet. 
The $\mathrm{N} 78 \mathrm{E}$ trend is pronounced in figure 17 and is probably related to similar trends in figure 16. The mechanism for these near east-west trends is not readily apparent but may represent conjugates of the $\mathrm{N} 22 \mathrm{E}$ and $\mathrm{N} 18 \mathrm{~W}$ trends.

Figure 18 is a frequency plot of the lineament analysis of the SKYLAB S-190B photography which covers the south-central portion of the Reno AMS Sheet. The strong northwest trends represent the Walker Lane fabric. The trends range from $\mathrm{N} 38 \mathrm{~W}$ to $\mathrm{N} 62 \mathrm{~W}$, but are stronger in the area of $\mathrm{N} 60 \mathrm{~W}$. Easterly trends occur in the range of $\mathrm{N} 2 \mathrm{OE}$ to $\mathrm{N} 4 \mathrm{OE}$ which are representative of the Bas in and Range and to a lesser extent to the influence of the Sierra Nevada Front. The N6OE trend is a singular spike and cannot be related to any specific structural trend, however in western Nevada more east-west trending structures have been noted in all of the images. These may be conjugates to the more northerly trends and have not been recognized previously.

Analys is of the entire Reno AMS Sheet by interpretation of the $1: 1,000,000$ scale LANDSAT imagery shows the more typical trends associated with Great Basin structures (fig. 19). There is a strong north-northeast trend ranging from north to N4OE, peaking at N18E. These trends are related to the basin-and range frontal faults and the Midas Trench system. Westerly trends are N80W and $\mathrm{N} 45 \mathrm{~W}$, the latter being a representation of the Walker Lane system. The N80W orientation is more difficult to assign to a tectonic fabric, but represents the east-west trends that have been apparent in all of the imagery. The absence of Tertiary movement along the east-west trends may indicate that the entire system is older than pre-Tertiary and that the northerly components which may be conjugates have been reactivated by tensional tectonics. 


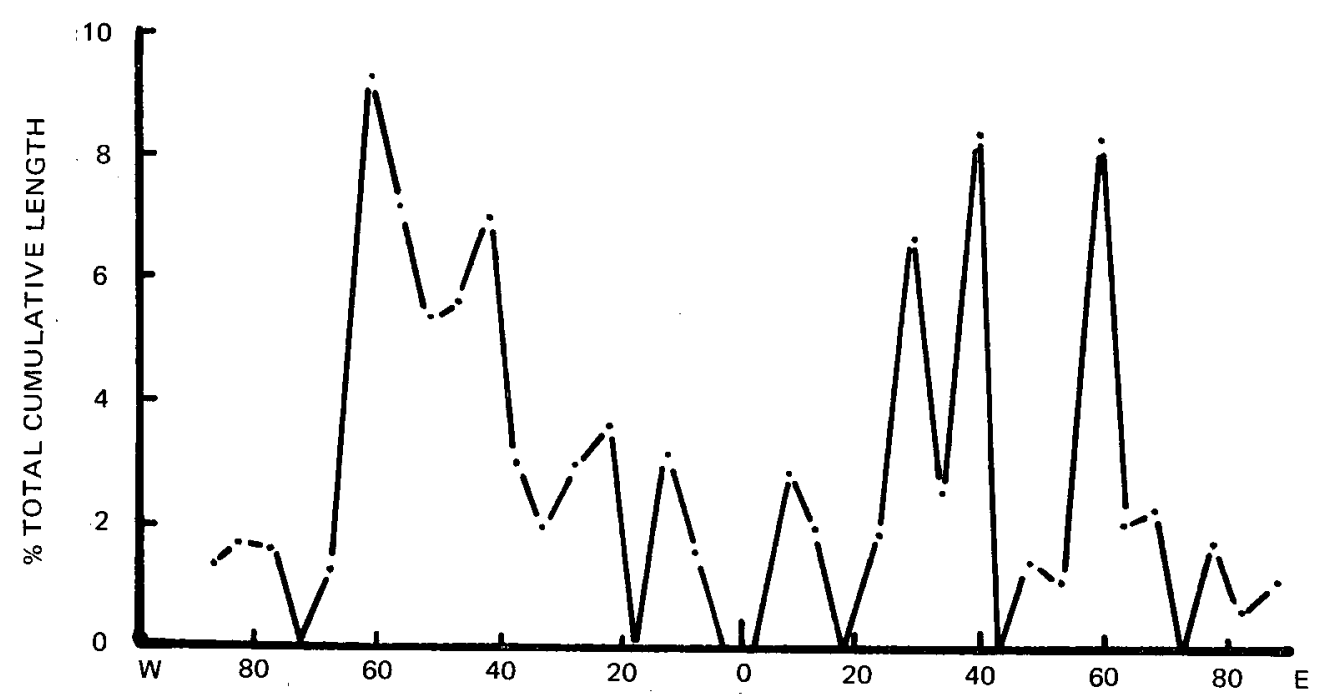

FIGURE 18. Frequency plot of lineaments from SKYLAB S-190B photography of the south-central portion of the Reno AMS Sheet.

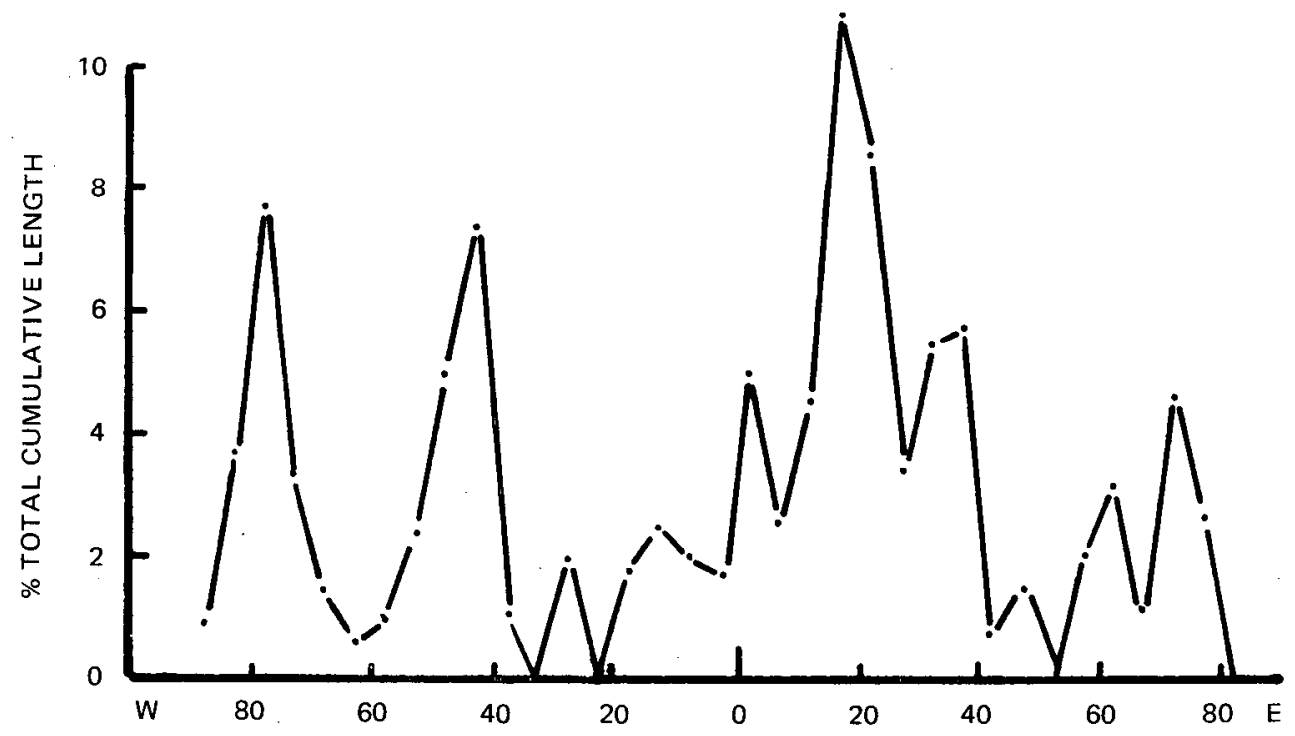

FIGURE 19. Frequency plot of lineaments for the entire Reno AMS Sheet from $1: 1,000,000$ LANDSAT imagery. 
RELATIONSHIP OF STRUCTURAL STYLE ALONG THE SIERRA NEVADA FRONT AND GEOTHERMAL ACT IVITY

The majority of hot springs in the Reno AMS Sheet occur in the Sierra Nevada Front subprovince. Most are low- to moderate-temperature systems except for Steamboat Hot Springs. There appears to be a correlation between the number of hot springs and/or geothermal areas and the structural setting. At the southern edge of the Reno AMS Sheet, the Sierra Nevada Front is marked by a well defined singular fault trace on the west side of Carson Valley. The trace of the fault is represented by an impressive scarp of more than $4000 \mathrm{ft}$ $(1200 \mathrm{~m})$. South of Carson City the frontal fault becomes irregular with fault segments between 1 and 2 miles $(1.5$ to $3 \mathrm{~km}$ ) long and forming a zigzag pattern (Moore, 1969): This pattern extends northward as distributive faulting to the south end of Washoe Valley (Trexler, 1977).

Where faulting becomes distributive increased hot spring activity becomes more apparent as in the Carson City area: Hobo, Saratoga, Carson and the spring near the State prison. Several wells have also encountered warm waters east of Carson City along the western flank of the Pine Nut Range (L. Garside, personal commun., 1978). This is not to imply that hot springs do not occur along the major frontal fault of the Sierra Nevada Block, e.g., Wally's Hot Spring is located approximately 2 miles $(3.2 \mathrm{~km})$ south of the southern edge of the Reno AMS Sheet. At Wally's Hot Spring drilling has confirmed only a small geothermal reservoir spacially associated with the frontal fault.

In Washoe Valley north of Carson City (A, fig. 20), a well marked frontal fault represents the eastern margin of the Carson Range. Here again a hot spring and well (Bower's Mansion) occur along the fault but apparently do not represent a large, near surface reservoir. A few miles north the singular, well marked frontal fault splays out into distributive faulting and warping (Thompson and White, 1964; Tabor and E1len, 1975; and Bingler, 1975). This demarcation from a linear fault trace to en echelon distributive faulting at 
45.

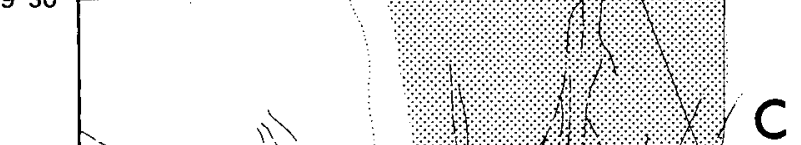

Reno

International

Airport

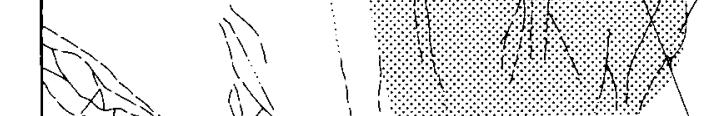

b

TRUCKEE MEADOWS

$+$

程 THERMAL AREA
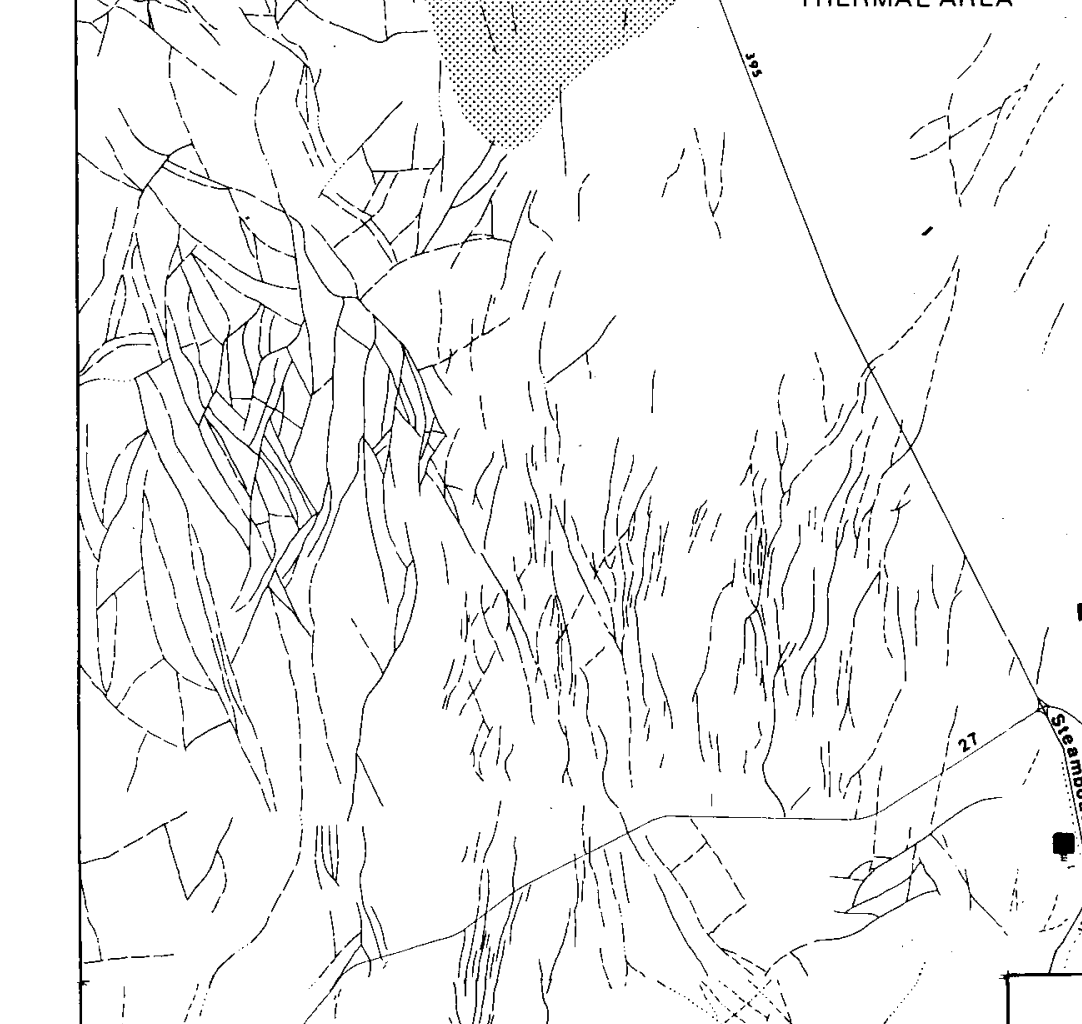

RHYOLITE $\rightarrow \because:$

DOME

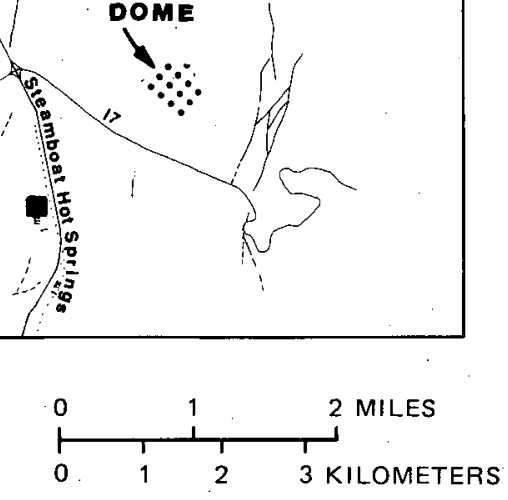

FIGURE 20. Faulting in the Steamboat Hot Springs area south of Reno, Nevada; from Thompson and White, 1964; Tabor and Ellen, 1975; unpublished data Nevada Bureau of Mines and Geology. 
$B$ is 6 miles $(10 \mathrm{~km})$ southwest of Steamboat Hot Springs and separates the Steamboat Hills from the main Sierra Nevada Block (Carson Range).

It appears that where the structural style changes, from a singular we11 marked frontal fault to gentle warping and distributive faulting, geothermal activity is more widespread. A recent study by Bateman and Scheibach (1975) has provided evidence of a geothermal reservoir north of Steamboat Hot Springs in the Reno, Nevada, area (C, fig. 20).

The distribution of young rhyolitic intrusive domes in the area of Steamboat Hot Springs is also shown in figure 20. The relationship between the alignment of the rhyolites and the northeast-trending faults in the area is readily apparent. This northeast-southwest trend corresponds to the regional scale structures associated with the Midas Trench system, e.g., Truckee River Trend and Carson Lineament of Shawe (1965).

Along the Sierra Nevada frontal fault, within the Reno AMS Sheet, areas with the greatest potential as sources of near surface geothermal energy for direct utilization occur where the range bounding fault becomes distributive due to warping or folding. The distributive nature of faulting may provide more deep circulating conduits for distribution of the geothermal activity over a large area.

After noting the apparent relationship between geothermal activity and changes in structural style along the Sierra Nevada Front in the Reno AMS Sheet a cursory examination of geothermal areas outside of the principal area of investigation was made. The area from the Garlock fault to Mono Lake, Calif. (fig. 21) was studied to ascertain if features noted to the north, such as interruption of a major structural feature causing distributive faulting, were operative to the south. Figure 21 shows the relationship between faults, volcanoes and thermal occurrences (hot springs, fumaroles and warm wells) along part of the Sierra Nevada Front. 


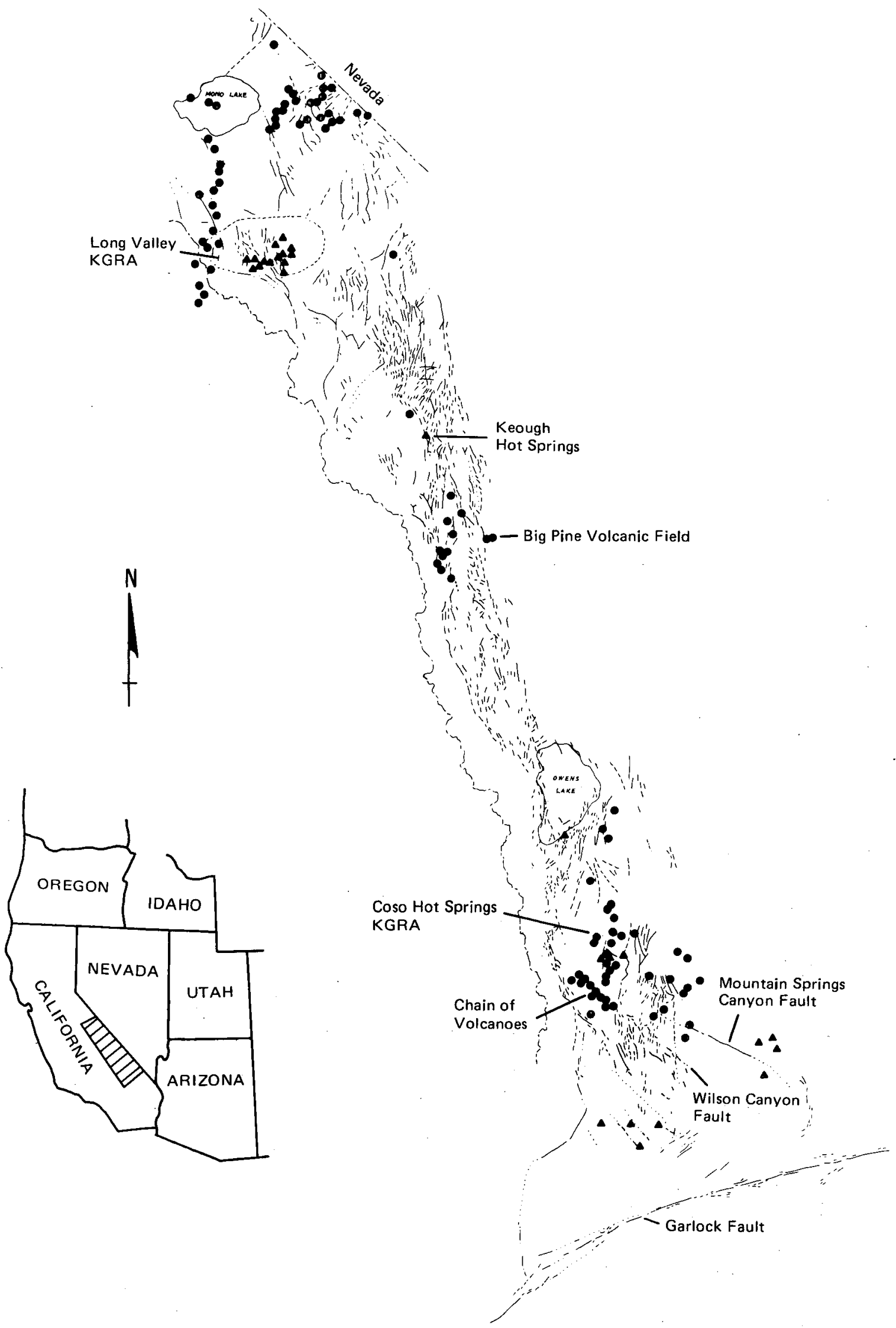

FIGURE 21. The relationship between volcanic-geothermal activity and faults along the Sierra Nevada front from the Garlock fault to Mono Lake, California. - - volcanoes, - - geothermal occurrence (hot springs, fumaroles, warm wells) from Fault Map of California (Jennings, 1975). 
It is readily apparent that the distribution of volcanoes (cinder cones) and areas of geothermal activity occur in three nearly equally spaced areas along the front. Each of these clusters of geothermal activity have a spatial relationship with volcanic activity and structural style. The major areas of activity coincide with marked changes in the character of the front and correspond to intersections with important lineaments.

In the Coso Mountains near the southern portion of figure 21 many young volcanoes as well as thermal springs and fumaroles are found. This area also contains the Coso Known Geothermal Resource Area (KGRA). The structure of the area is dominated by north-south trending faults, however northwest and northeast trending faults are present. Two northwest trending faults, the Wilson Canyon fault and the Mountain Springs Canyon fault (fig. 21) cut the southern Coso Mountains. The Wilson Canyon fault forms a predominant lineament from Searls Lake to the Sierra Nevada Front, along part of which a chain of volcanoes has formed. West of the Coso Mountains the Sierra Nevada shift drastically to a westerly trend and abruptly shift back to the normal north-south trend. The perturbation in the trend of the Sierra Nevada Front occurs along the extension of the volcanic alignment in the Coso Mountains.

The Big Pine volcanic field to the north is dominated by Quaternary basaltic cinder cones and flows. A single occurrence of geothermal activity north of the area is indicated by Keough Hot Springs. Orientation of faults surrounding the area is the typical north-south trend associated with the Sierra Nevada Front. However, within the Big Pine volcanic field there are northwest and northeast trending faults. Again the northwest trending faults correspond in trend to a major westerly shift of several miles to the Sierra Nevada Front.

Further north in the Long Valley KGRA the rocks are typically Quaternary volcanics dominated by rhyolitic ash-flow tuffs. A strongly developed 
northwest orientation of faults in the area parallels another westerly shift of the Sierra Nevada Front.

This pattern of westerly offsets of the Sierra Nevada Front and associated increase in geothermal activity is apparent northward into Nevada. The intersection of northwest and northeast trending 1 ineaments with the Sierra Nevada Front produce 1oci of geothermal activity. The Carson Lineament and Truckee River Trend (Midas Trench system) appear to be northeasterly oriented and are associated with geothermal activity where they intersect the Sierra Nevada Front. Geothermal activity appears to be more predominant throughout the extent of the northeast trending 1 ineaments in west-central Nevada.

Geothermal and volcanic activity are associated with northwest trends at the termination of the Sierra Nevada Front by northwest trending structures (Wa1ker Lane). Some investigators suggest that the northwest trends become more westerly north of Reno and align with the Susanville-Mt. Lassen-Mt. Shasta trend (Wright, 1976).

A corollary between geothermal activity and recent volcanism along the Sierra Nevada Front can be made with the mid-Tertiary volcanic activity associated with the Walker Lane in southern and central Nevada. Miocene volcanism tends to be concentrated where major right-1ateral offset faults die out or display multiple branches and en echelon arrangement (Carr, 1974). Carr also suggests that,

"An especially favorable locus appears to be wherever the large right-lateral zones step to the right several miles and where their ends are connected by northeast-trending faults, most of which have a small component of left-lateral offset. The northeast trending faults can be regarded as rifts or spreading centers; commonly they are partially obscured by the products of volcanism."

It appears that mechanisms controlling the emplacement of volcanic rocks during the mid-Tertiary are not dissimilar to the factors controlling the location of more recent volcanic rocks. Where major lineament trends, typically NW-SE, NE-SW and north-south in west-central Nevada, intersect or cause 
disruption of other trends; these sites appear to be favorable loci for volcanic activity and in many cases associated geothermal activity. These intersections and/or disruption of cross-cutting trends produce distributive faulting and warping which produces near-surface, area11y wide-spread, moderate temperature geothermal resources to occur.

The intersection of northeast and northwest trending structures and their individual intersection with north-south oriented regional scales features such as the Sierra Nevada Front indicate that they are important in the development of the patterns reflected in the topography. These patterns are evident at both regional and local scales. At local scales, individual ranges within the western Basin and Range show similar range front effects as the "saw-tooth" appearance caused by the intersection of northeast and northwest trends (fig. 22). The area of figure 22 is along the western edge of the Reno AMS Sheet, 30 miles $(48 \mathrm{~km})$ south of Dixie Hot Springs. It is interesting to note that the northeast-southwest trending faults are predominant in an area near the suspected trace of the Walker Lane. Early to middle Tertiary age dikes are oriented northwest-southeast sub-parallel to the NW-SE trending faults. There appears to have been multiple periods of displacement along both fault trends, since each is cut by the other. The "saw-tooth" nature of the range front also indicates successive movement along the conjugate fractures into the Quaternary based on the morphology of the range front.

RELATIONSHIP BETWEEN GEOTHERMAL OCCURRENCES AND YOUNG VOLCANIC ROCKS WITH THE STRUCTURES IN THE RENO AMS SHEET

Major fault trends in the Reno AMS Sheet and their relation to geothermal areas and hot springs are shown in figure 23 (faults from Preliminary Geologic map of Nevada, MF 609). At this scale northwest trending faults related to the Walker Lane are located in the northwestern portion of the map area. Two faults with similar trends fall within the map area near the southern boundary. These faults appear to be related to a major concentration of northwest 
(1) 42, (25)

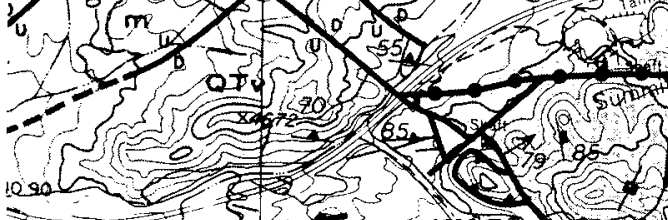

(1)

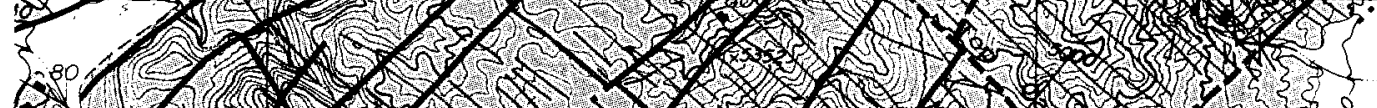

5.1.1

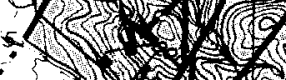

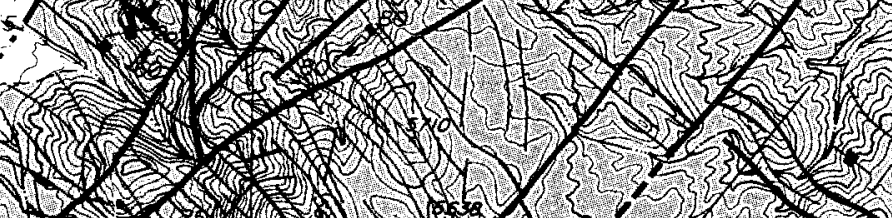

2(1)

N(I)

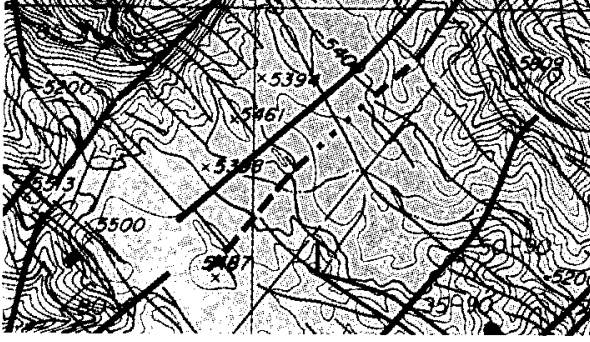

FIGURE 22. Portion of reconnaissance geologic map and sections, Sand Springs Range, Churchill County, Nevada. Nevada Bureau of Mines, 1963. Scale: $1: 31,680$.
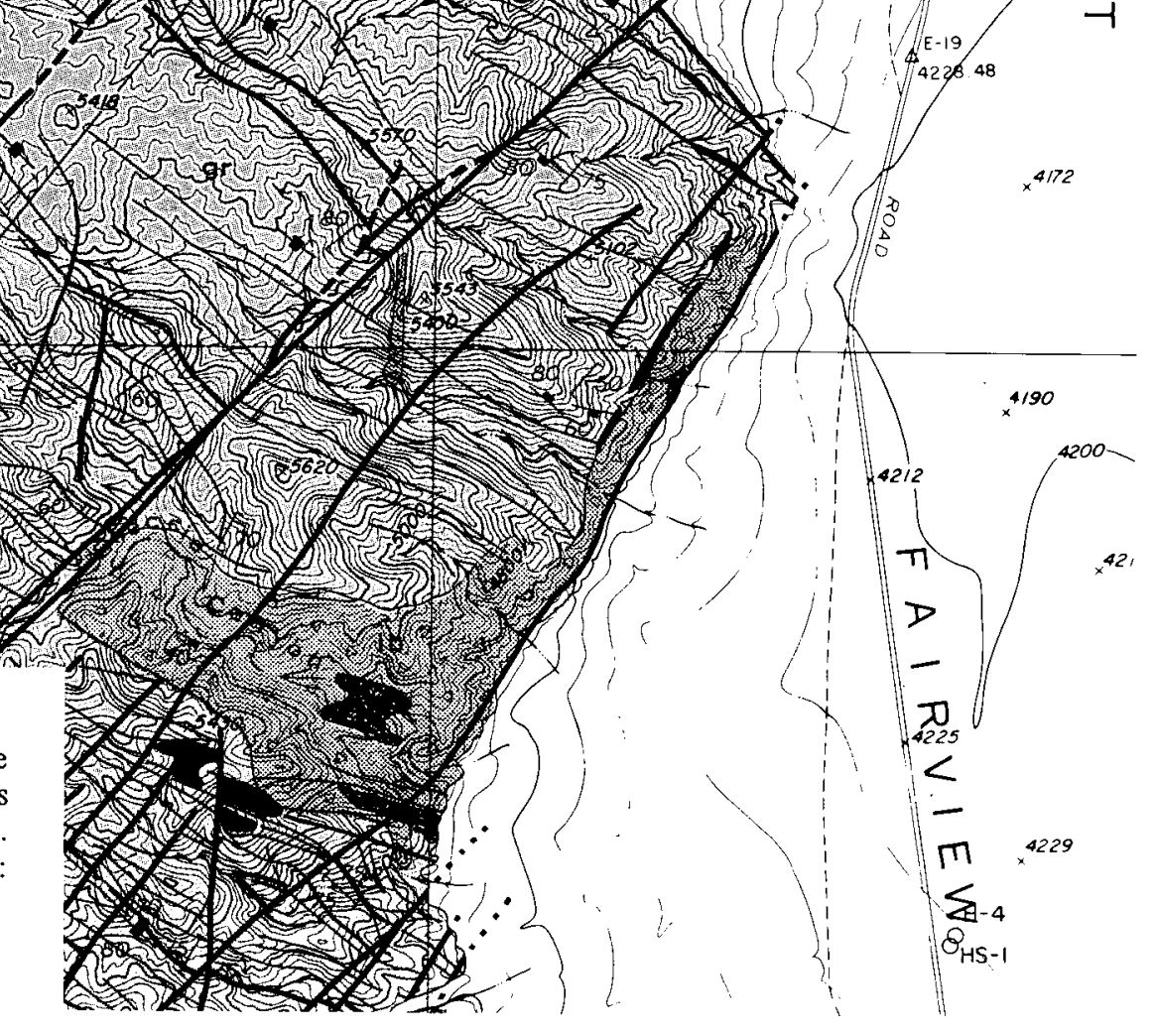


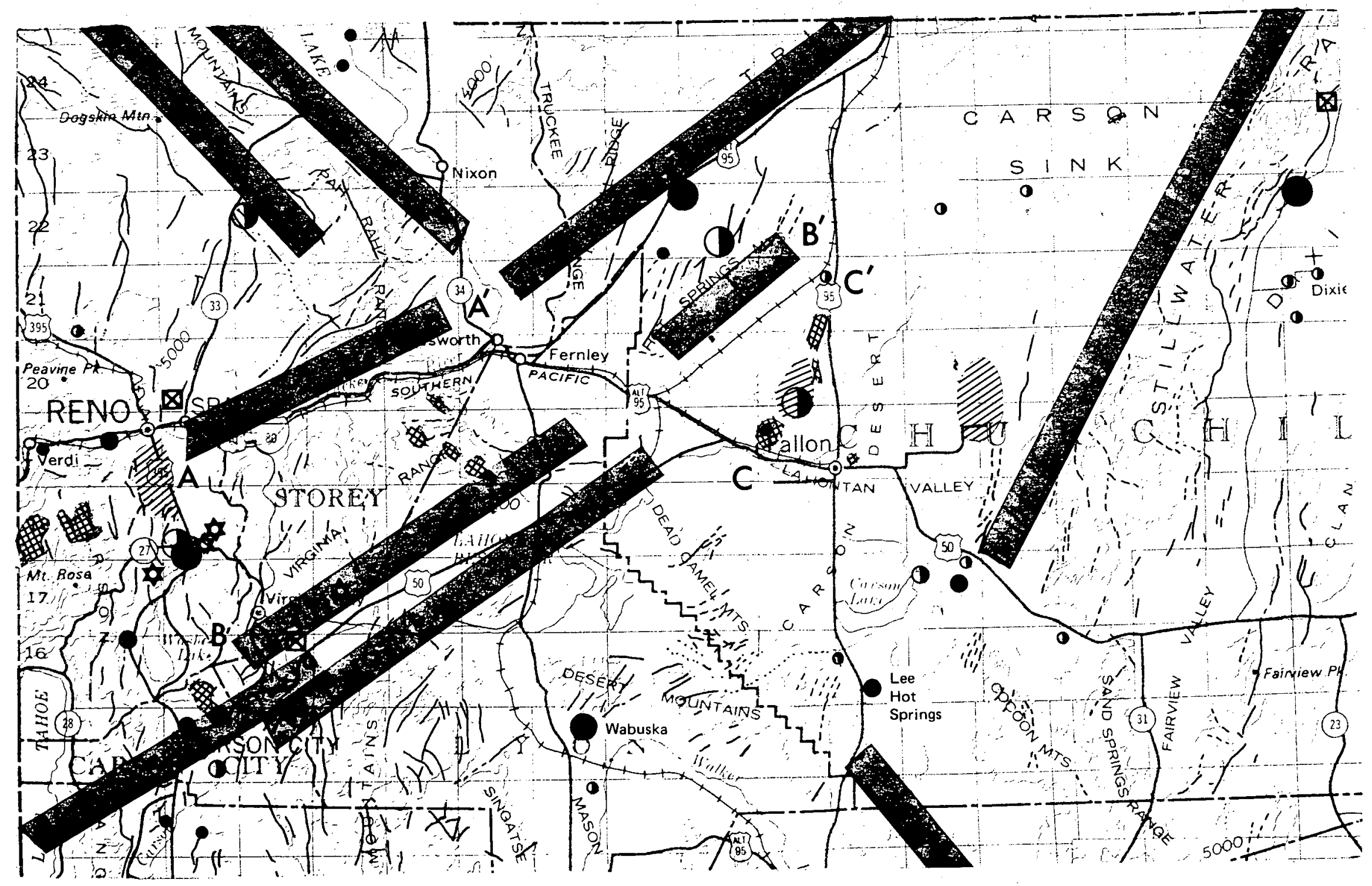

FIGURE 23. Relationship between faults (-), LANDSAT lineaments ( $)$, rhyolite domes ( $)$, hot springs ( $\bigcirc$ ), hot wells ( 0 ), thermal areas $(/ / /)$, mines or tunnels with hot waters $(\mathbb{X})$, and basalts $<6$ m.y. old ( $)$. 
trending faults with right-lateral offset south of the Reno AMS Sheet near Walker Lake (Hardyman, 1978). Fault orientations in the southwestern and eastern portions of the quadrangle are predominantly north trending and correspond to the Sierra Nevada and basin-and-range trends, respectively.

The central portion of the Reno AMS Sheet is conspicuously devoid of northwesterly and northerly trends associated with the Walker Lane and Sierra Nevada--basin-and-range structures. The majority of fault trends in the central portion of the map area are northeast to east-west. This zone of anomalous structural trends apparently disrupts the Walker Lane along an east-west line between Wabuska Hot Springs and Lee Hot Springs in the south. To the north-west, the northern boundary of the zone of disruption coincides with the east-northeast west-southwest oriented Truckee River Trend ( $A-A^{\prime}$, fig. 23).

The Truckee River Trend not only represents the northern boundary of the disruption of the Walker Lane but is spacially associated with the termination and segmentation of the Sierran Front (along the western slope of the Carson Range near Reno). The correlation of several viable geothermal areas such as Brady's-Desert Peak to the east and the Reno area at the western termination of this trend make it one of the most promising locus of geothermal activity in western Nevada.

The Truckee River Trend and similar northeast trends in the Hot Springs Range along the northern edge of the Carson Sink are probably related to the Midas Trench system. Recent work by the Seismological Laboratory of the University of Nevada, Reno using Nevada Test Site underground nuclear detonations along a line of stations trending northwest across the Carson Sink indicates anomalous weak arrivals and strong second arrivals in seismograms near the northern edge of the sink. These anomalous arrivals indicate that the base of the crust is downdropped on the northwest side (K. Priestley, 
personal commun., 1978). These preliminary data tend to confirm the existence of a subcrustal structure which trends northeast-southwest and may be the causative mechanism for the surface manifestation which has been termed the Midas Trench (Rowan and Wetlaufer, 1973).

Volcanic rocks of basaltic and silicic composition less than $6 \mathrm{~m} . \mathrm{y}$. old crop out at 20 localities in the Reno AMS Sheet. The distribution of these intrusive and extrusive rocks shown in figure 23 was modified from Stewart and Carlson (1976). Several andesitic flows shown on their map are older than 9 m.y. (M. L. Silberman, personal commun., 1977) and were deleted from figure 23. A distinct northeast-southwest alignment of these recent volcanic rocks with associated similar trending lineaments is apparent.

Four rhyolitic intrusive domes occur in the Reno AMS Sheet. Three of these domes are in the Steamboat Hot Springs area and (as mentioned ear1ier) aligned parallel to the regional northeast-southwest trends associated with the Midas Trench system (fig. 20). The fourth young rhyolitic dome is located 9 miles $\left(15 \mathrm{~km}\right.$ ) east of Virginia City along (lineament $\mathrm{B}^{-B^{\prime}}$, fig. 23) the Carson Lineament as defined by Shawe (1965).

Other manifestations of recent volcanic activity includes the basalt flows west of Reno atop the Carson Range which are aligned with a thermal area south of Reno and the extension of the Truckee River Trend. A basaltic cinder cone north of Carson City is aligned along the extension of one of the segments of the Carson Lineament. Other surface manifestations of the recent volcanic activity include the mar at Soda Lakes and the rift-like structure of Upsal Hogback, both near Fallon. The alignment of these features is more northerly (N25E, C-C', fig. 23) and is sub-parallel with the lineament along the western front of the Stillwater Range to the east. A thermal area between Soda Lakes and Upsal Hogback has been found by 01msted and others, 1975. They state,

"Although few faults are exposed, the generally northnortheasterly alignment of Soda Lakes, Upsal Hogback, and the 
intervening thermal area suggest faults at depth, possibly along a zone of rupture in the consolidated rocks of Tertiary and (or) pre-Tertiary age."

Their observations undoubtedly describe many of the problems associated with trying to define the structural features in an area of Quaternary basin fill. The area covered by the Carson Sink appears to have great potential for geothermal energy based on the recency of the volcanic activity.

The development of the Carson Sink was probably late in the evolution of the Basin and Range. Mid-Miocene spreading directions were N68E-S68W ( $\pm 5^{\circ}$ ) (Zoback and Thompson, 1978). Sometime in the past $14 \mathrm{~m} . \mathrm{y}$. a clockwise rotation of approximately $45^{\circ}$ has taken place with the present direction of extension being $\left(\mathrm{N} 65 \mathrm{~W}-\mathrm{S} 65 \mathrm{E}\left( \pm 20^{\circ}\right)\right)$. The north-northeasterly alignment of recent volcanic rocks in the interior of the Carson Sink (Soda Lakes-Upsal Hogback) correspond well with the present extensional directions as developed by (Zoback and Thompson, 1978). The alignment of volcanic rocks and the development of a rift with similar alignment between Soda Lakes and Upsal Hogback fits wel1 with Nakamura's (1977) model of indicators of tectonic stress. The late stage development of the sink along N65W-S65E extension directions is further established by the late Quaternary age (300,000 years) for basalts at Upsa1 Hogback (M. L. Silberman, personal commun., 1977).

The young age of the Carson Sink and its apparent rift-like extensional mechanism for development make it one of the viable geothermal areas in the Reno AMS Sheet. Again subsurface faulting as inferred by 01msted and cthers, 1975 undoubtedly provides conduits for deep circulation of waters and widespread near surface distribution of the geothermal waters. The near-surface areally widespread occurrences will probably provide the best sites for exploitation as a direct utilization application of geothermal energy. 
SITE SPECIFIC STUDIES WITHIN THE RENO AMS SHEET

Three areas within the Reno AMS Sheet were selected for site specific studies using medium- to large-scale low sun-angle photography. The low sun-angle photography requested to support this phase of the program was not made available and this severely limited the quality of the site specific studies because uniformly superior photography was not available of each site selected, as was the case for the previous site specific investigations in the Winnemucca AMS Sheet.

The three areas selected included the Brady's-Desert Peak area in the north-central portion of the study area, Dixie Hot Springs in the extreme eastern portion of the study area, representing typical basin-and-range structures, and Steamboat Hot Springs selected for detailed investigation of the relationship between faulting (structural contro1) and geothermal activity. The relationships which were observed in the Steamboat Hot Springs-Sierra Nevada Front were described previously. Areas of geothermal activity and recent volcanic rocks correspond with the disruption of the Sierra Nevada Front.

\section{BRADY'S HOT SPRINGS - DESERT PEAK AREA}

Structural interpretation of the Brady's Hot Springs-Desert Peak area was made using 1954 Army Map Service (AMS) aerial photography. This photography does not provide enhancement of 1 inear structural features which would be apparent at low angles of solar illumination. To supplement available AMS photography high altitude U-2 photography at a scale of $1: 120,000$, which covers the north portion of the area, was also interpreted. This U-2 photography was not obtained with low sun-angle illumination.

The major structural trend in the area is northeast. Figure 24 shows the frequency distribution of faults mapped from the AMS photography. The strong bi-modal northeast trends dominate the area with only minor occurrences with 


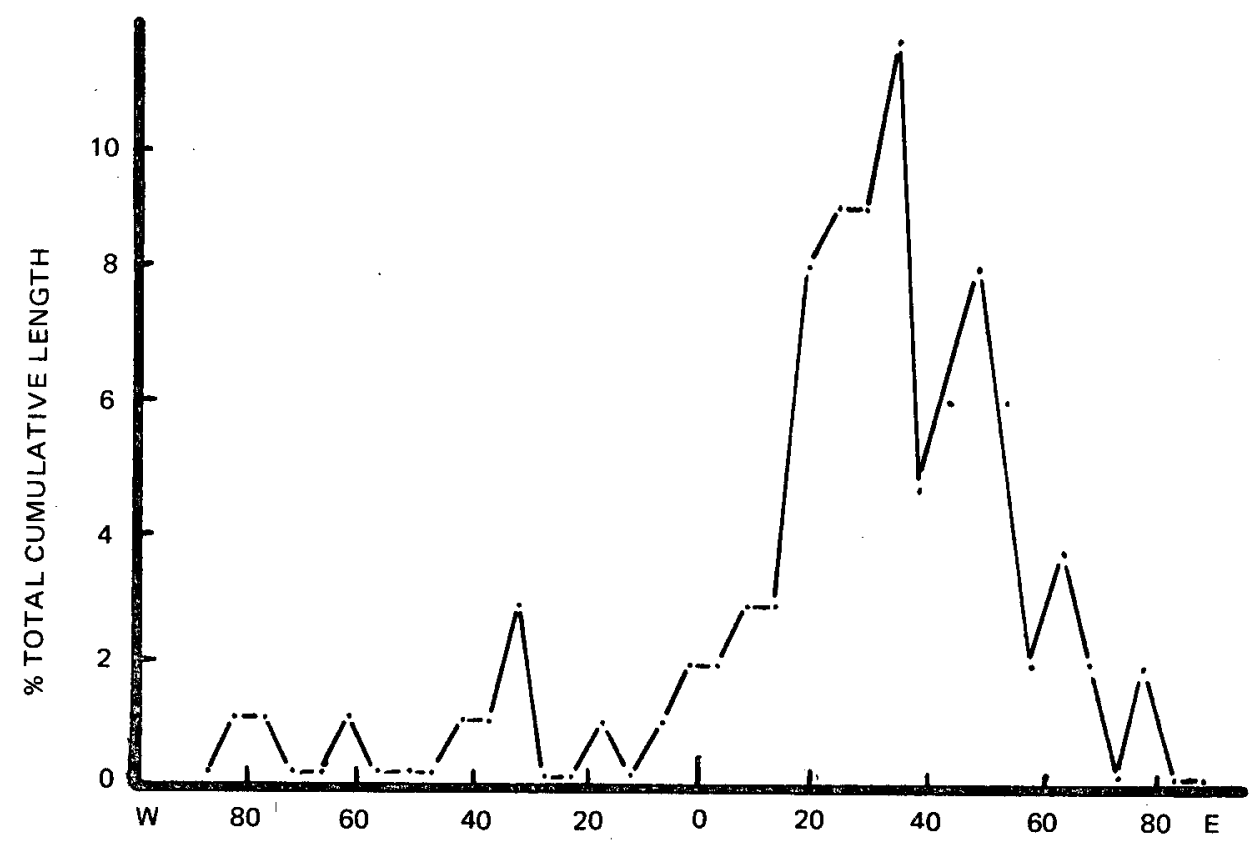

FIGURE 25. Frequency plot of faults in Brady's Hot Springs-Desert Peak area (U-2 photography).

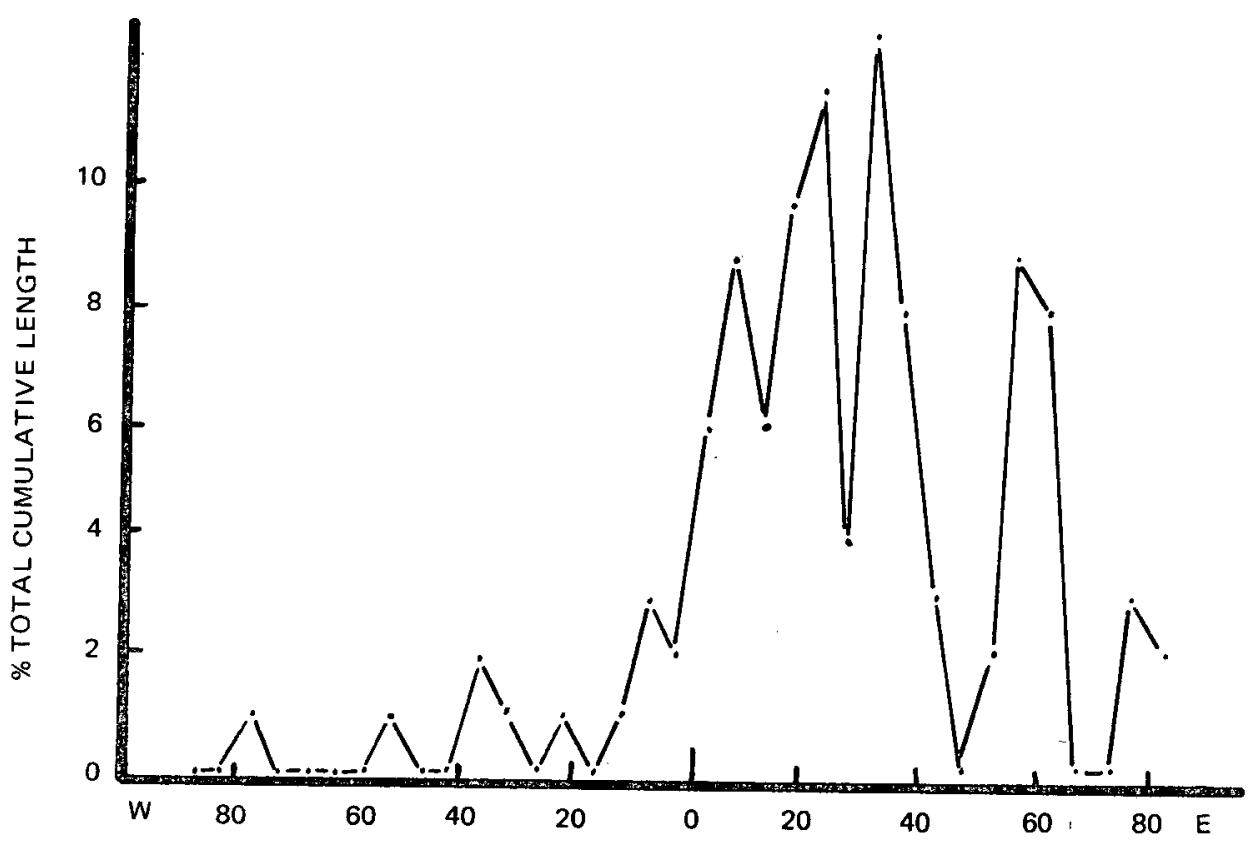

FIGURE 24. Frequency plot of faults in Brady's Hot Spring-Desert Peak area (conventional AMS photography). 
northeast trends. This predominance of northeast trending faults is significant in an area peripheral to the Wa1ker Lane.

Similar orientations of structural features were interpreted from the U-2 photography which covered only the northern portion of the AMS photo coverage. A predominant northeast trend is apparent at these scales and is also bi-modal. Only minor influence of northwest trending features are apparent in the frequency distribution plot for the U-2 photography (fig. 25).

As stated previously the predominance of northeast trending structures in the Brady's Hot Springs-Desert Peak area is surprising. It appears to be a combination of tectonic trends based on the bi-modal nature of the northeast trends. Instinctively one would relate the more northerly components to basinand-range structures and the N40-50E trends to the Midas Trench system. The combination of these two NNE-NE structural trends and the lack of Walker Lane related structures are the most interesting aspects of this structural interpretation.

Recent geologic mapping in the Brady's Hot Springs-Desert Peak area indicates that northwest-southeast trending structures are present in the Tertiary basement rocks of the Hot Springs Range (John F. Heiner, personal commun., 1978). The apparent lack of northwest trends visible in the airphotos is undoubtedly due to the poor quality of the photography. Mapping shows that northwest trending faults in the bedrock areas have displacements of several meters.

The detailed geologic mapping confirms the existence of conjugate northeast-southwest and northwest-southeast trends. In the Hot Springs Range it appears that the northeast-southwest trend is younger than the northwestsoutheast trend which is undoubtedly genetically related to the Walker Lane. The similar conjugate trends have been noted previously in the Sand Springs Range (fig. 22) in the southeast portion of the Reno AMS Sheet. 
Similar trends which appear to be extensions of the Hot Springs Range lineament near $A^{\prime}$ ( $f i g$. 23) have been discussed by Bell and Slemmons (in press) and Sanders and Slemmons (in press). In the area south of Pyramid Lake a northwest-trending zone of right-slip transcurrent faulting which represents a portion of the Walker Lane exhibits characteristics of movement in the late Pleistocene through Holocene. A northeast-southwest zone of faulting known as the 01inghouse fault which exhibits Recent movement is included in the Truckee River Trend. This fault also shows repeated movement during the Quaternary and the latest episode of movement may be as young as historic (1869) Sanders and Slemmons (in press).

Although major geothermal anomalies have not been located in the immediate area of the intersection of the Walker Lane and the Truckee River segment of the Midas Trench system major occurrences of geothermal activity are located within 30 miles $(48 \mathrm{~km})$ of the junction in al1 directions except southeast along the suspected trend of the Walker Lane.

\section{DIXIE HOT SPRINGS}

Dixie Valley Hot Springs and the surrounding area was selected as a geothermal area typifying basin-and-range structural controls. A preliminary structural interpretation employing conventional AMS mapping photography was made. This type of aerial photography is of marginal- to poor-quality and has a nominal scale of $1: 60,000$.

The preliminary analysis indicates a strong representation of typical basin-and-range trends (N18E) figure 26. The frequency of trends shows a marked skewness in the northeasterly directions with minimal occurrences westerly of N50W. The distribution is asymmetrically bi-modal between N27W to $\mathrm{N} 68 \mathrm{E}$ with a minor deviation around $\mathrm{N} 78 \mathrm{E}$. The secondary maxima at $\mathrm{N} 38 \mathrm{E}$ and more easterly components probably represent overprinting of Midas Trench related trends. 
60 .

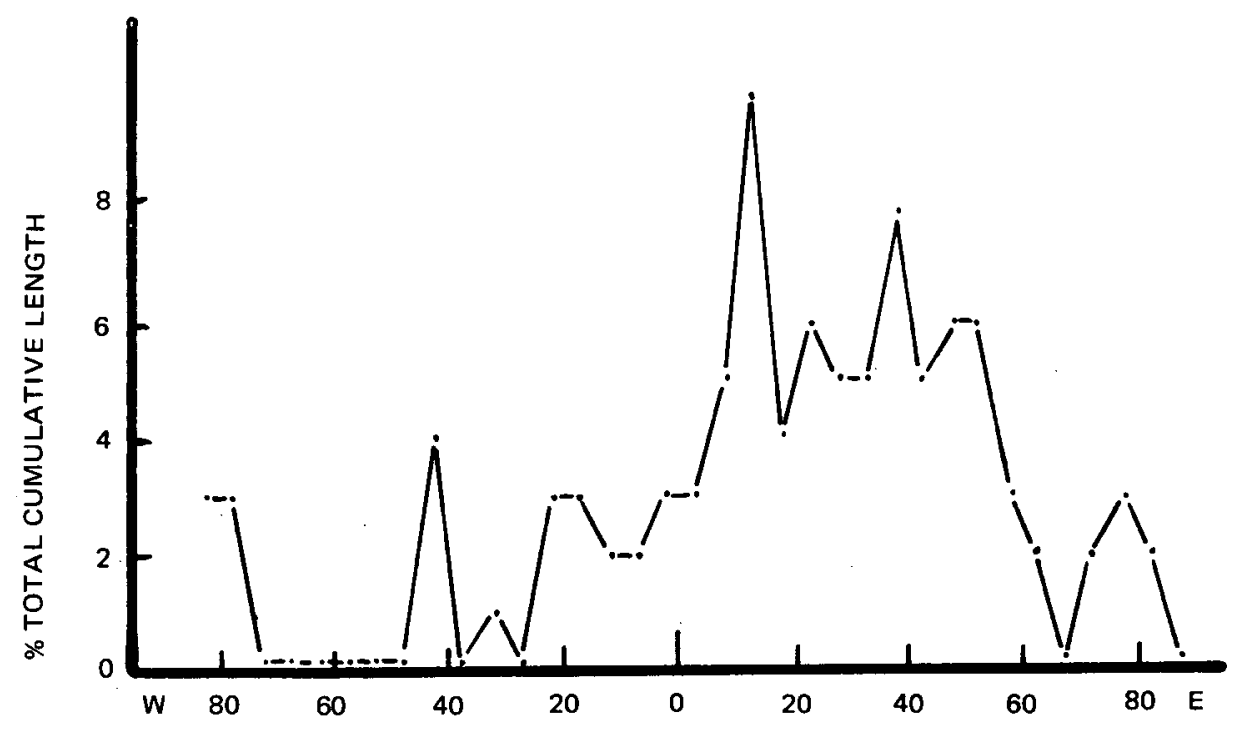

FIGURE 26. Frequency plot of faults in the Dixie Valley Hot Springs area. Nevada. 
A minor maxima at $\mathrm{N} 42 \mathrm{~W}$ undoubtedly represents the influence of the Walker Lane trend. The east-west orientations are not easily explained, but may be secondary conjugates of the predominant northerly trends.

More detailed analysis was performed on large scale $(1: 12,000)$ low sunangle photography obtained by D. B. Slemmons in 1970. Figure 27 shows the complex nature of faulting in the Dixie Hot Springs area. The Dixie Valley fault zone is composed of two principal splays: the range front fault and the valley branch which is subparallel to the range front fault. Areas of detailed analysis along the two splays are indicated in figure 27 . Figures 28 through 31 depict the various surface expressions of the fault zone and the relationships to major springs and liquefaction phenomena. Low-sun angle illumination has produced highlighting on eastward facing scarps and shadowing on westward facing fault scarps.

Figure 28 contrasts two graben structures in the range front and valley branch faults in an area where surface expression of the faults is not complicated by the presence of liquefaction phenomena. The range front graben is generally less than a few tens of meters in width and formed during the 1954 Dixie Valley earthquake. The fracture pattern exhibits Riedel and P-shears that, along this portion of the frontal fault, indicate a left-lateral component of displacement. The graben of the valley branch fault averages several hundred meters in width and exhibits successively more distinct faulting toward the margins of the graben. Topographic profiles in figure 29 shows the development of the graben structures in both branches of the fault system. The margin faults of the graben were reactivated during the 1954 earthquake.

The range front fault zone exhibits several right-angle junctions between fault segments (fig. 30). These can be compared with ideal Riedel and conjugate Riedel shears (Tschalenko, 1970), and are a response to the local 
FIGURE 27. Map of the Dixie Valley area showing the range front and valley segments of the Dixie Valley fault zone. Shaded areas correspond to figures covering detailed analysis.

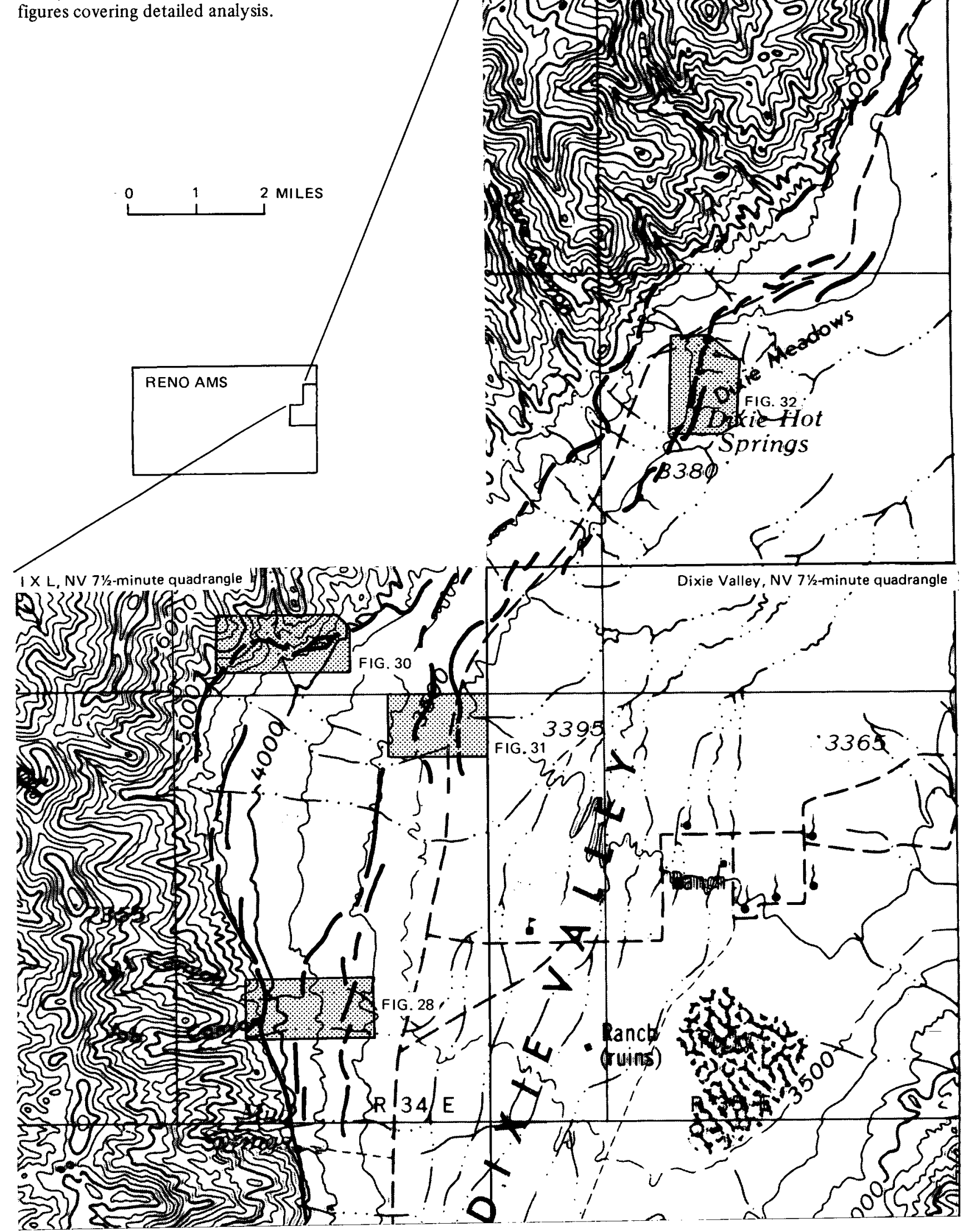


63.
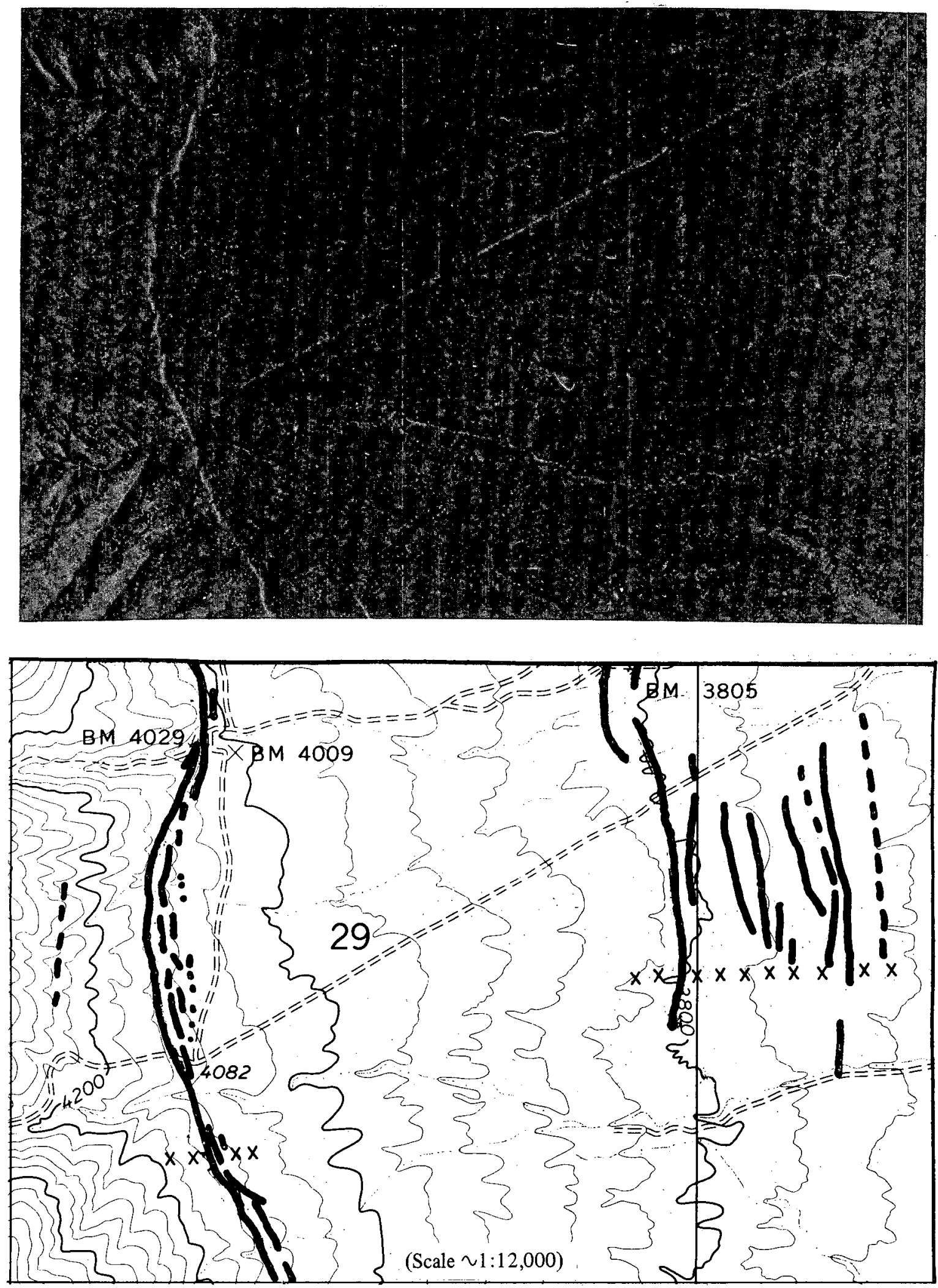

FIGURE 28. Photograph and map of the central portion of the IXL quadrangle showing the relationship between the range front and valley segments of the Dixie Valley fault system. $X \times X$ indicate locations of scarp profiles. 

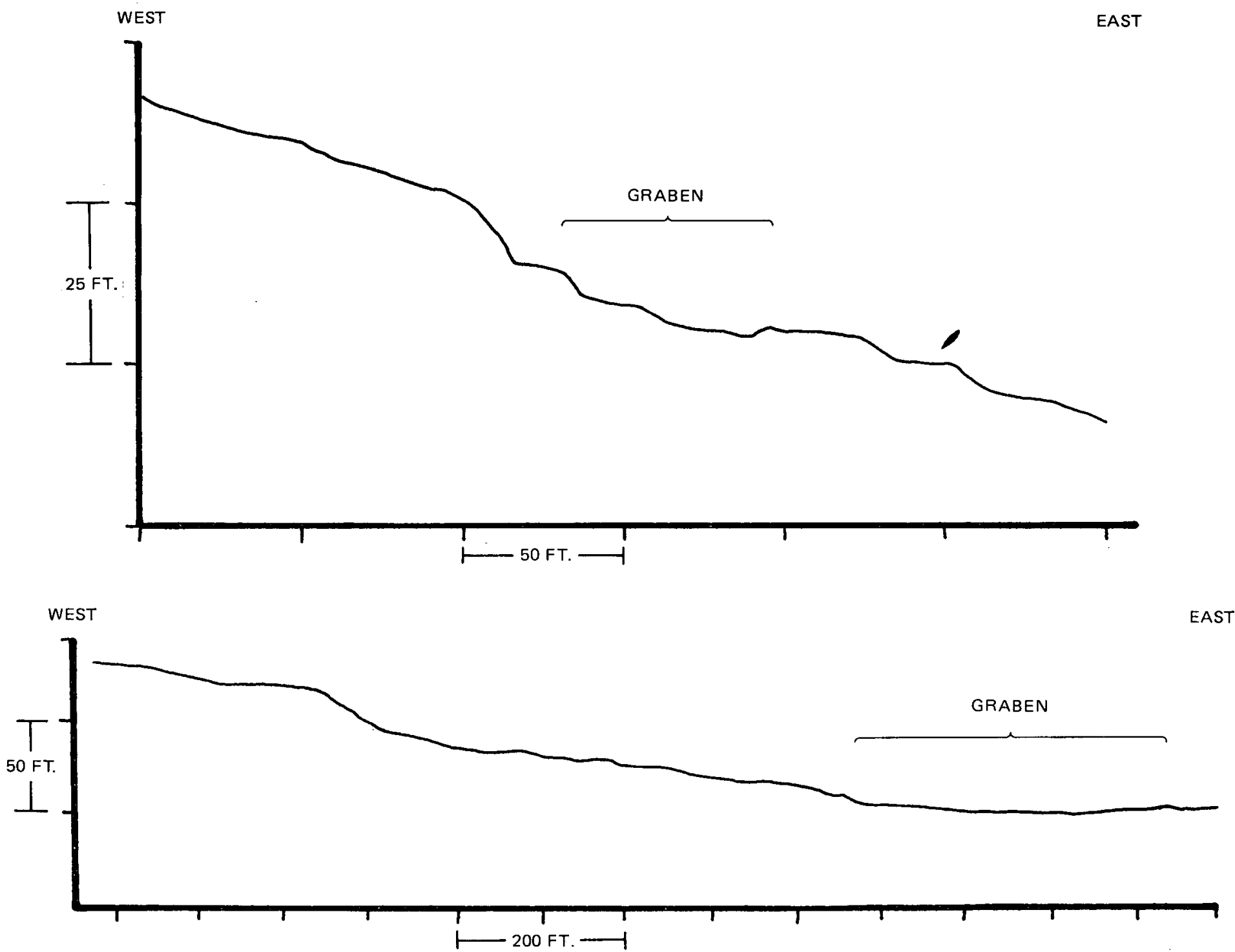

FIGURE 29. Profiles across range front fault (upper) and the valley segment (lower) of the Dixie Valley fault zone. Location of profiles indicated in figure 28 . Note scale variations between profiles. 


\section{c}
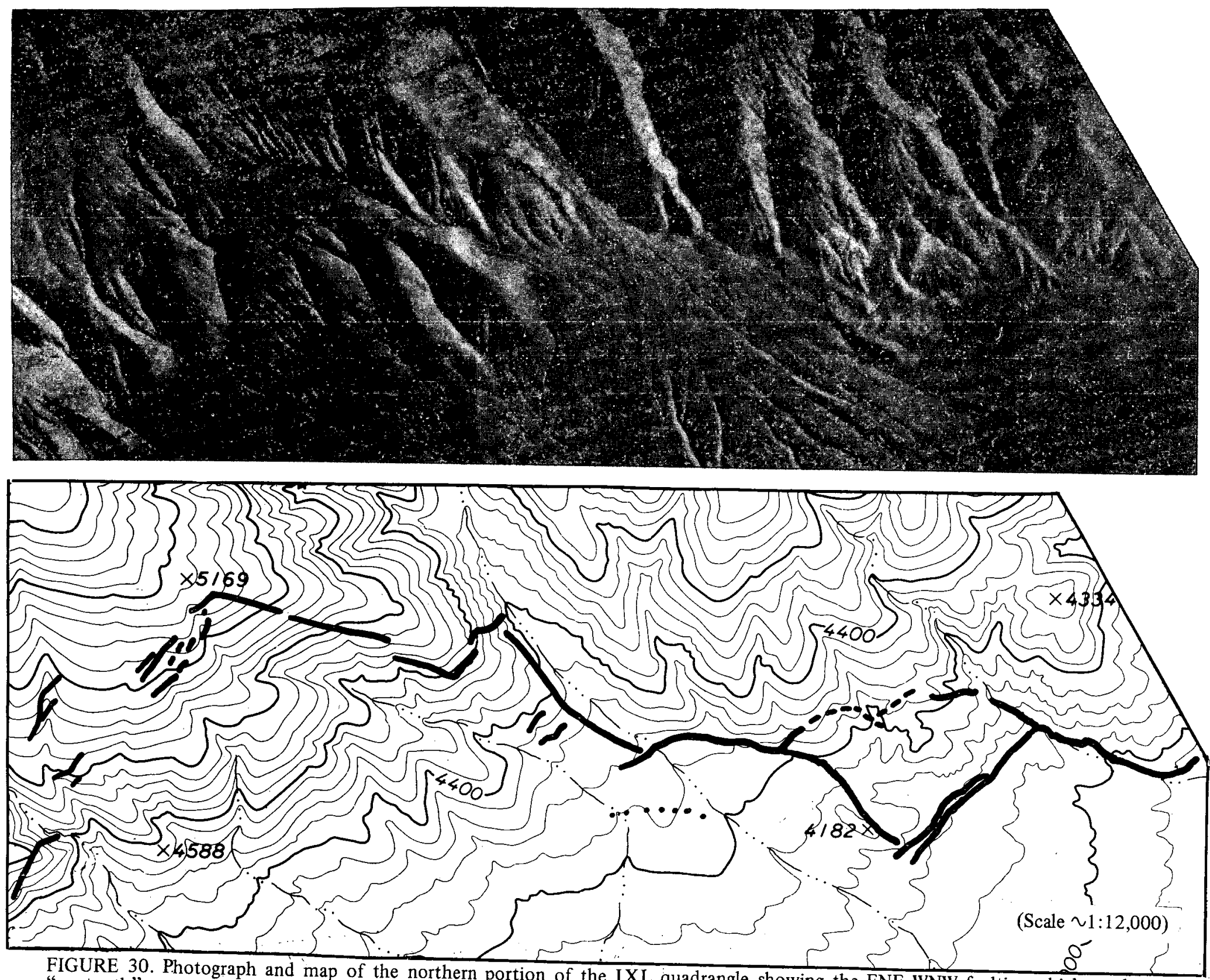

"sawtooth" appearance. 
stress field similar to that of the regional shear pattern evidenced in figure 22 (conjugate shear patterns of the Sand Springs Range to the south).

Figure 31 illustrates a portion of the valley branch fault bordering the playa. The expression of the more eastern fault segments is complicated by liquefaction phenomena. The fault scarp is distinct within the alluvial fan deposits. The fault trace is more subdued at the playa margin, with slumps, subtle topographic relief and vegetational and tonal alignments.

Figure 32 shows a portion of the valley branch fault that extends southward from Dixie Hot Springs across Dixie Meadows. Surface expression of the fault is dominated by liquefaction phenomena. The fault trace is marked by slumping and by tonal and vegetationa 1 ineaments. At this site, there appears to be a sufficient water supply under the appropriate conditions to produce springs that generally coincide with the intersection of fault segments or lie along fault traces. The presence of both cold and hot springs in this area is not atypical of other basin-and-range areas (L. Trowbridge Gross, oral commun., 1978). This suggests the possibility of: 1) preferential heat conduits to produce hot springs, and 2) local, near-surface artesian conditions that preclude or minimize heating of the water by the underlying geothermal heat source.

Dixie Hot Springs and the adjoining cool springs occur along the northnortheast trending valley segments of the Dixie Valley Fault zone, where the fault strike changes to east-northeast. The change in orientation of the valley fault at this point coincides with a similar change in orientation of the range front fault (fig. 27). A similar change in both the range front and valley segments of the zone in the northern portion of the IXL 7 1/2minute quadrangle may be the locus of geothermal activity at depth. Several shallow irrigation wells in the northern half of the Dixie Valley $71 / 2$ minute quadrangle to the east have encountered warm waters. 

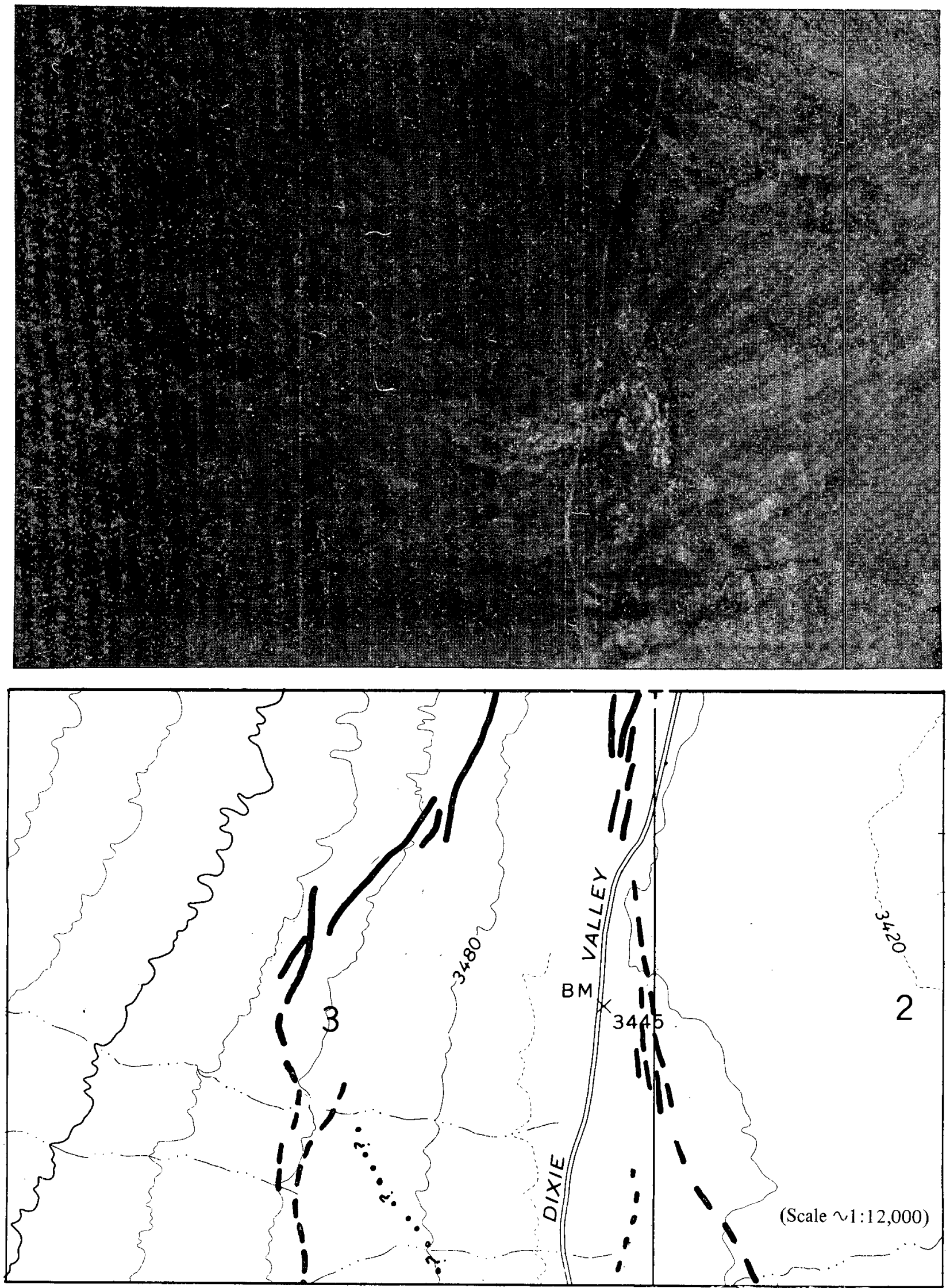

FIGURE 31. Photograph and map in the northeast portion of the IXL quadrangle showing two splays of the valley branch fault. Western splay in alluvial fan; eastern splay at playa margin exhibiting liquefaction effects. 


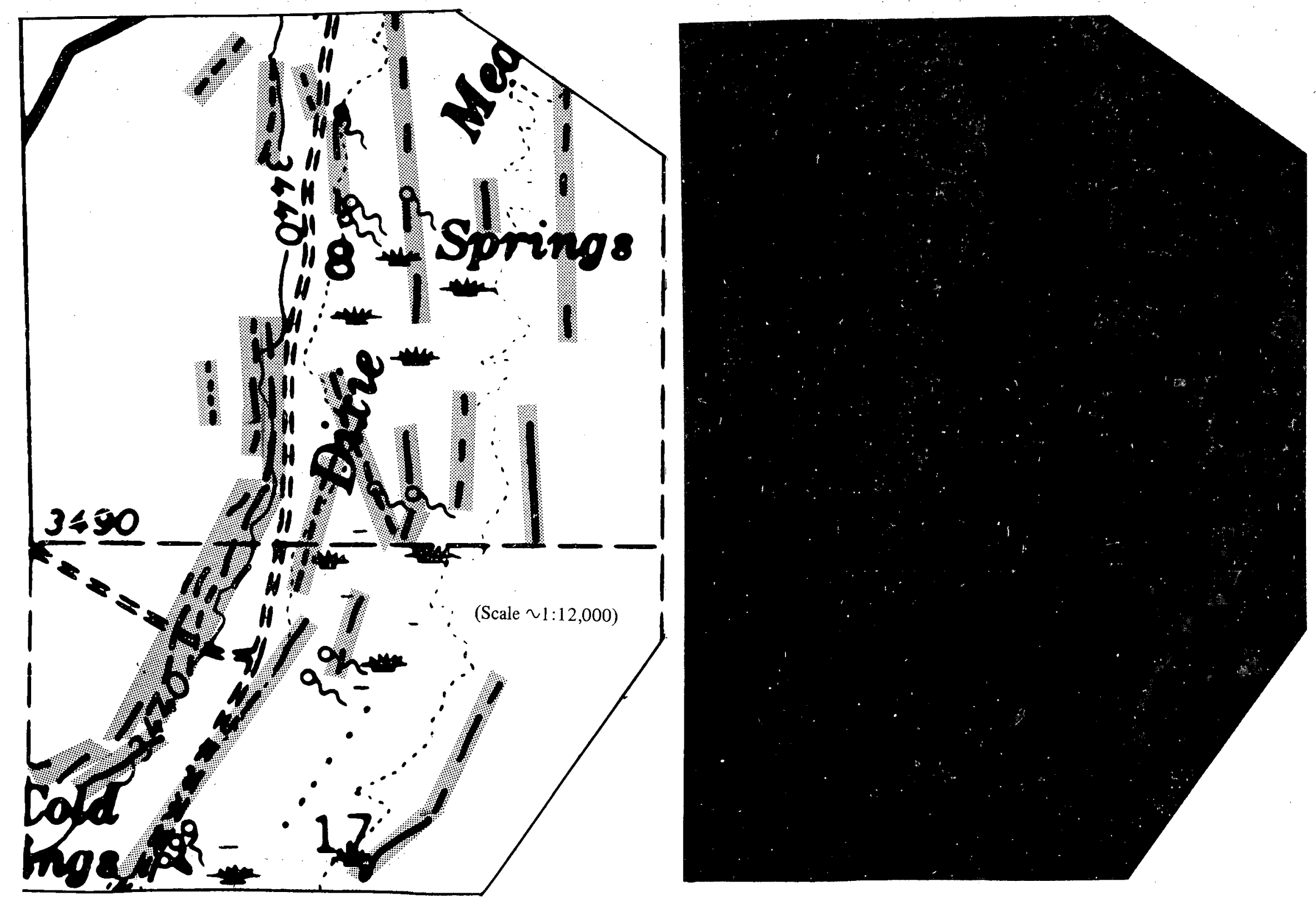

FIGURE 32: Photograph and map of the central portion of the SE $1 / 4$ of Dixie Hot Springs 15 -minute quadrangle show abundant liquefaction related features associated with the valley segment of the Dixie Valley fault. Note relationship between faulting and spring locations. 
EVALUATION OF DATA TYPES AND FORMATS

\section{GRAVITY MAPS}

Gravity data at regional scales $1: 250,000$ and smaller indicate regional subcrustal structure of large magnitude. These data provide an indication of the regional gravity trends which may be related to regional lineament trends visible on 2-dimensional pictorial formats (satellite imagery and photography).

Gravity data provide supporting information on the existence of major basement structures beneath valley fill deposits. Northeast trending structures visible on LANDSAT imagery in the East Range have been confirmed beneath valley-fill deposits in Buena Vista Valley (Robert Reeves, personal commun., 1977). It is not suggested that gravity data be acquired in support of geothermal exploration programs, but if these data are available they may be useful in supporting regional reconnaissance.

\section{AEROMAGNETIC DATA}

Aeromagnetic data, like gravity data, provide information on the origin of regional lineament trends, e.g., the Oregon-Nevada Lineament in the Winnemucca AMS Sheet. In some cases magnetic anomalies are associated with extrusive volcanic rocks which tend to mask the deeper structures. However if there is a preferred alignment of extrusive volcanic rocks the aeromagnetic data may provide information about these preferred alignments. In areas lacking geologic maps these data may provide important information concerning alignments of volcanic rocks. Although no age can be inferred without geologic maps, the alignments may provide data on tectonic trends along which intermediate to mafic intrusive rocks have risen to the surface or have been emplaced near the surface.

\section{LANDSAT DATA}

LANDSAT imagery provides information of regional scale lineament trends. In the central Basin and Range Province the trends may be as old as 
pre-Cambrian but appear to be important in the localization of geothermal activity where they intersect or cause disruption of other regional structural trends e.g., the Sierra Nevada Front.

LANDSAT data at multiple scales and multiple format (enhanced and unenhanced) should be used whenever possible. Computer enhanced LANDSAT imagery did not provide appreciably more information for the west-central Basin and Range Province but may provide more information on structural trends and interaction of trends in other areas with a different tectonic history. For regional reconnaissance LANDSAT imagery provides the most cost effective format for lineament interpretation and it is available over the entire earth's surface. S KYLAB PHOTOGRAPHY

Photographic products obtained by SKYLAB provide the necessary transition from regional to site specific data analysis. S-190A photographs are most useful as a transition mechanism from LANDSAT to U-2 low sun-angle photography. S-190B photographs with their superior resolution provide coordination and integration of site specific work with the regional lineament associations. S-190B photography is of such high quality that it can be enlarged to $1: 250,000$ scale and interpreted using conventional airphoto interpretation techniques.

The availability of SKYLAB photographic products is limited to the orbital configuration and constraints imposed by other priorities of the space oriented mission. If exploration is planned in areas which have been photographed by the S-190A or S-190B photographic systems aboard SKYLAB, one should take advantage of the information contained in these data formats.

\section{LOW SUN-ANGLE PHOTOGRAPHY (LSAP)}

It has been demonstrated that at site specific scales of investigation low sun-angle photography provides the maximum amount of information on structural detail (Clark, 1971; Lyon and others, 1970; Walker and Trexler, 1977). Simultaneously acquired multiple scale photography, at such varied 
scales as provided by high altitude aircraft (nominally 1:120,000 @ 6 in. F.L., $1: 60,000$ @ 12 in. F.I. and 1:30,000@ 24 in. F.L.), result in formats that allow the interpreter to integrate the regional lineament patterns to the site specific areas.

Low altitude ( $1: 12,000$ scale) low sun-angle photography was used during the course of the second phase of this study when multiple scale morning and afternoon low sun-angle photography were not available. The detail of structurally controlled topographic features such as fault scarps are readily apparent using the low sun-angle illumination technique. The necessity of large scales is precluded by the detail available at smaller scales. That is, 1:30,000 scale low sun-angle photography in the Winnemucca AMS Sheet provided sufficient detail to define the relationship between individual hot springs and fault control. In addition the simultaneously obtained 1:120,000 scale photos allowed for ease of transition to regional scale interpretation and relationship to major crustal lineaments.

Scales of low sun-angle photography for structural interpretation of areas on the order of several hundred square miles need not exceed 1:24,000. The increased cost for larger scale photography is not justified by the increase in the amount of data capable of being extracted.

\section{SUMMARY AND CONCLUSIONS}

This study presents an integrated approach employing variously derived imagery, photography, and geophysical data in two areas of the Basin and Range Province to evaluate lineament analysis as an exploration technique for geothermal energy. One area, which encompasses a portion of the Battle Mountain Heat Flow High (Sass, and others, 1971), was studied to determine the relationship between regional and local structural controls and geothermal activity. Four geothermal sites within this area were studied in detail. These sites, all within the Winnemucca AMS Sheet, include: 1) Leach Hot 
Springs, 2) Kyle Hot Springs, 3) Beowawe geothermal area and 4) Buffalo Valley Hot Springs. The first three areas have been defined as known Geothermal Resource Areas (KGRA). Area two is encompassed by the Reno AMS. Sheet and included three regions that are dominated by different styles of tectonic activity. These areas are: 1) the Sierra Nevada Front to the west, 2) the Walker Lane, and 3) the Basin and Range to the east.

The primary study area (Winnemucca AMS Sheet) consists of approximately $7,420 \mathrm{sq}$. mi. $(19,219 \mathrm{sq}$. km) of typical basin-and-range structures. This area was integrated with regional lineament patterns obtained by evaluation of LANDSAT mosaics of Nevada. Lineaments defined by Rowan and Wet laufer (1973 and 1975) were also incorporated into this analysis.

An interpretation and analys is of SKYLAB S-19OB photography provided the necessary transition from spacecraft data products to airborne photographic products. High altitude U-2 low sun-angle photography at $1: 120,000$ and $1: 30,000$ scales provided an excellent format for site specific structural investigations of geothermal areas. Other data used in conjunction with the 2-dimensional pictorial formats included gravity and aeromagnetic data. These data provide an indication of the third dimension of the surface manifestations of aligned features that are referred to as lineaments.

The results of the first phase of the study indicate that major sites of geothermal activity within the Winnemucca AMS Sheet occur a long northeast trending structures for example, e.g., although Buffalo Valley Hot Springs has no apparent surface manifestation of structural control in the immediate spring area, nearby structural and lithologic relationships tend to indicate that these springs are coincident with subsurface northeast trending faults. Two major lineament trends dominate the structural setting in the area of Battle Mountain Heat Flow High. These trends are not the north to northeast basin-and-range structures but are instead older and more pervasive northeast 
and north-northwest striking lineaments. These regional lineaments, which do not coincide with the typical basin-and-range structures and in many instances off-set these structures are: 1) the northeast trending Midas "Trench" system of Rowan and Wetlaufer (1973), and 2) the Oregon-Nevada Lineament of Stewart and others (1975).

The Midas "Trench" system, or genetically related structures that have similar trends, are often associated with hot spring activity and the distribution of recent volcanic rocks. In each case-study in the Winnemucca AMS Sheet, the hot springs occur where basin-and-range faulting or the northnorthwest trending Oregon-Nevada Lineament are disrupted or off-set by northeast trending structures related to the Midas Trench 1 ineament.

The relationships observed in the initial phase of the study (area one) were applied to a more structurally (and/or more recently) complicated area in the western Basin and Range Province (area two).

Although significantly different tectonic forces have been operating in western Nevada, as compared to north-central Nevada, similar relationships between geothermal activity and recent volcanism are apparent. The intersection of northeast trending regional lineaments with the other two operative tectonic styles (e.g., Walker Lane and Sierra Nevada Front) appears to provide the subsurface conduits for either near-surface emplacement of magma and/or localization of volcanic activity or deep circulation of meteoric waters to sufficient depths in areas of high geothermal gradient accompanied by heating and convective rising along similar zones of fracture.

The near surface accumulation of hot water apparently increases, in the Sierra Nevada Front area, where the frontal fault is disrupted by northeast trending structures. This association between the intersection of generally northerly trending faults (Sierra Nevada and Basin and Range) and more northeast striking structures prompted further investigation of regional structural 
intersections and geothermal activity along the Sierra Nevada Front from the Garlock fault north to Mono Lake, Calif. This analysis confirmed the original observation that geothermal and volcanic activity were spatially associated with structural controls that tended to parallel regional northeast and northwest trending lineaments, e.g., Coso KGRA, Long Valley KGRA and the Mono Basin. A site that has similar features as the above areas is the Big Pine volcanic area, which has not received consideration as a potential geothermal area as indicated by the regional structural relationships.

In both areas studied, the intersection of northeast-southwest and northwest-southeast trending regional structures or complementary structures appears to be the loci for major geothermal activity. This is demonstrated on both local and regional scales. Local scales are represented by Kyle and Leach Hot Springs; regional scales are represented by Steamboat Hot Springs. The largest scale areas include the intersection of the northeast and northwest striking regional structures that localize the Battle Mountain Heat Flow High (intersection of the Midas Trench and the Oregon-Nevada Lineament) and the Carson Sink (intersection of the Walker Lane and the Midas Trench).

From the results of this investigation it is apparent that lineament analysis can provide important information at both regional and local scales on the localization of geothermal activity. Areas with similar structural affinitives in the Basin and Range or Sierra Nevada Front that exhibit similar associations of intersection or disruption should be investigated further. 


\section{REFERENCES}

Abde1-Gawad, M. and Tubbesing, L. (1974) Transverse shear in southwestern North America - a tectonic analysis: Ch. 3 in Proc. of the First Inter. Conf. on the New Basement Tectonics, Utah Geological Assoc. Pub. No. 5.

Bateman, R. L., and Scheibach, R. B. (1975) Evaluation of geothermal activity in the Truckee Meadows, Washoe County, Nevada: Nevada Bur. Mines and Geology Rept. 25.

Bel1, E. J, and Slemmons, D. B. (in press) Recent crustal movements in the central Sierra Nevada-Walker Lane Region of California-Nevada: Part II, The Pyramid Lake right-slip fault zone segment of the Walker Lane recent crustal Movement: Tectonophysics.

Bingler, E. C. (1975) Guidebook to the Quaternary geology along the western flank of the Truckee Meadows, Washoe County, Nevada: Nevada Bur. Mines and Geology Rept. 22.

Carr, W. J. (1974) Summary of tectonic and structural evidence for stress orientations at the Nevada Test Site: U. S. Geol. Survey open-file rpt. $74-176,53 \mathrm{p}$.

Christiansen, R. L. and Lipman, P. W. (1972) Cenozoic volcanism and platetectonic evolution of western United States. II Late Cenozoic: Phil. Trans. Roy. Soc. London Ser. A 271: 249-84.

Clark, M. M. (1971) Comparison of SLAR images and sma11-scale, low sun-angle aerial photographs, Bul1. Geol. Soc. Am.; vol. 82, p. 1735-1742.

Eaton, G. P. (1975) Characteristics of a transverse crustal boundary in the Basin and Range Province of southern Nevada, [abs.] Geol. Soc. America Annual Mtg., Salt Lake City, UT.

Erwin, J. W. (1974) Bouguer gravity map of Nevada: Winnemucca Sheet, Nevada Bur. Mines and Geology, Map 47.

Erwin, J. W. and Berg, J. C. (1977) Complete Bouguer gravity map of Nevada, Reno Sheet: Nevada Bur. Mines and Geology.

Garside, L. J. (1974) Geothermal exploration and development in Nevada through 1973: Nevada Bur. Mines and Geology, Rpt. 21.

Hamilton, Warren and Myers, W. B. (1966) Cenozoic tectonics of the western United States: Rev. Geophysics, v. 4, p. 509-549.

Hardyman, Richard F. (1978) Volcanic stratigraphy and structural geology of Gillis Canyon Quadrangle, northern Gillis Range, Mineral County, Nevada: unpublished Phd. dissertation, University of Nevada, Reno.

Hoppin, R. A. (1974) Lineaments: their role in tectonics of central Rocky Mountains, AAPG Bul1., v. 58, no. 11, p. 2260-2273.

Jennings, C. W. (1975) Fault map of California: Geologic Data Map No. 1, California Div. Mines and Geology. 
Koizumi, C. J., Rya11, A. and Priestley, K. F. (1973) Evidence for a highvelocity lithospheric plate under northern Nevada: Bull. Seism. Soc. Am., v. 63, no. 6, p. 2135-2144.

Levandowski, D. W., Jennings, R. V. and Lehman, W. T. (1974) Relations between ERTS lineaments, aeromagnetic anomalies and geological structures in north-central Nevada: Proc. of the First Inter. Conf. on the New Basement Tectonic, Utah Geol. Assoc. Pub. No. 5.

Lyon, R. J. P., Jose, Mercado, and R. Campbell, Jr. (1970) Pseudo-radar, very high contrast: aerial photography at low sun-angles: Photogramm. Engx. vol. 36 .

McKee, E. H. (1970) Fish Creek Mountains tuff and volcanic center, Lander County, Nevada: U. S. Geol. Survey, Prof. Paper 681.

Moore, J. G. (1969) Geology and mineral deposits of Lyon, Douglas and Ormsby Counties, Nevada: Nevada Bur. Mines Bu11. 75.

Nakamura, K. (1977) Volcanoes as possible indicators of tectonic stress orientation - principle and proposal: Jour. Vol. and Geotherm. Research 2 (1977) p. 1-16.

Nevada Bureau of Mines (1965) Vela Uniform Project Shoal VUF-1001 Final Report, plate 3.

Oesterling, W. A. (1960) Areal geology of the Geysers and vicinity, Eureka and Lander Counties, Nevada: geologic map, Southern Pacific Co. Mineral Resource Survey.

(1962) Geothermal power potential of northern Nevada: paper presented at AIME, Pacific So. West Mineral Conf.

O1msted, F. H., Glancy, P. A., Harrill, J. R., Rush, F. E. and Van Denburgh, A. S. (1975) Preliminary hydrogeologic appraisal of selected hydrothermal systems in northern and central Nevada: U. S. Geol. Survey open-file rpt. $75-56$.

Quade, J. G. and Trexler, D. T. (1975) An analysis of the airborne data from NASA's Mission No. 268 over geothermal areas of northern Nevada: report to the LBL Geotherma1 Group.

Robinson, E. S. (1970) Relations between geologic structure and aeromagnetic anomalies in central Nevada: Geol. Soc. America Bu11., v. 81, p. 20452060 .

Rogers, D. K. (1975) The Carson Lineament: its influence on recent left-latera1 faulting near Carson City, Nevada: Abstracts with Programs, p. 1250, Geol. Soc. of America Annual Meeting, Salt Lake City, Utah.

Rowan, L. C. and Wetlaufer, P. H. (1973) Structural geologic analysis of Nevada using ERTS-1 images: a preliminary report, in Symposium on significant results obtained from the Earth Resources Technology Satellite-1, Vol. 1, technical representation, Sec. A: Nat'l Aeronautics and Space Administration, Paper G-20, p. 413-423. 
Rowan, L. C. and Wetlaufer, P. H. (1975) Iron-absorption band analysis for the discrimination of iron-rich zones, Type III Final Report, NASA/Goddard Space Flight Center.

Ryal1, A. (1977) Earthquake risk in the Nevada region: Bull. Seism. Soc. America, v. 67, no. 2, p. 517-532.

Sales, J. K. (1966) Structural analysis of the Basin Range Province in terms of wrench faulting, unpub. Ph.D. thesis, Univ. of Nevada.

Sanders, C. and Slemmons, D. B. (in press) Recent crustal movements in the central Sierra Nevada-Walker Lane region of California-Nevada: Part III, The Olinghouse Fault Zone: Recent Crustal Movement: Symp. Proc. Tectonophysics.

Sass, J. H. and others (1971) Heat flow in the western United States: Jour. Geophys. Research, v. 76, no. 26, p. 6376-6413.

Shawe, D. R. (1965) Strike-slip control of Basin-Range structure indicated by historical faults in western Nevada: Geol. Soc. America Bull., v. 76, p. 1361-1378.

Stewart, J. H. and Carlson, J. E. (1976) Geologic map of north-central Nevada: Nevada Bur. Mines and Geology, Map 50.

Stewart, J. H., Walker, G. W. and Kleinhampl (1975) Oregon-Nevada Lineament, Geology, May, p. 265-268.

Suppe, John, Powel1, C. and Berr, R. (1975) Regional topographic, seismicity, Quaternary volcanism, and the present day tectonics of the western U. S.: Am. Jour. Sci., v. 275A, 397-436.

Tabor, R. W., and E1len, S. (1975) Geologic map of the Washoe City quadrangle, Washoe City Folio, Environmental Series, Nevada Bur. of Mines and Geology.

Tatlock, D. B. (1969) Preliminary geologic map of Pershing County, Nevada: U. S. Geological Survey open-file map, 1:200,000.

Thompson, G. A. and Burke, D. B. (1974) Regional geophysics of the Basin and Range Province: Ann. Rev. Earth and Planetary Sci.: v. 2, p. 213-238.

Thompson, G. A., and White, D. E. (1964) Regional geology of the Steamboat Springs area, Washoe County, Nevada: U. S. Geol. Survey Prof. Paper 458-A.

Trexler, D. T. (1977) Geologic map of the Carson City quadrangle, Nevada Environmental Series, Nevada Bureau of Mines and Geology.

Tschalenko, J. S. (1970) Similarities between shear zones of different magnitude: Geol. Soc. America Bull., v. 81, p. 1625-1640.

Walker, P. M. and Trexler, D. T. (1977) Interpretive techniques, uses and flight planning considerations for low sun-angle photography: Photogram. Eng. and Remote Sensing, Vol. XLIII, No. 4. 
Wallace, R. E. (1977) Profiles and ages of young fault scarps, north-central Nevada: Geol. Soc. America Bull., v. 88, no. 9, p. 1267-1281.

Wise, D. U. (1963) An outrageous hypothesis for the tectonic pattern of the North American Cordillera: Geol. Soc. America Bull., v. 74, p. 357-362.

Wollard, G. P. and Joesting, H. R. (1964) Bouguer gravity anomaly map of the United States (exclusive of Alaska and Hawaii), U. S. Geol. Survey.

Wollenberg, H. A., Asard, F., Bowman, H., McEvilly, T., Morrison and Witherspoon, P. (1975) Geothermal Energy Resource Assessment, Lawrence Berkeley Lab. UCID-3762, p. 91.

Wright, Lauren (1976) Late Cenozoic fault patterns and stress fields in the Great Basin and westward displacement of the Sierra Nevada block, Geology, v. 4, p. 489-494.

Zoback, M. L., and Thompson, G. A. (1978) Basin and Range rifting in northern Nevada: clues from a mid-Miocene rift and its subsequent offsets: Geology, v. 6, p. 111-116.

Zones, C. P. (1958) Petrographic and petrofabric study of the metamorphic rocks north of Carson City, Ormsby County, Nevada: Univ. of Nevada-Reno M.S. thesis, $80 \mathrm{p}$. 